\title{
Consequences of Civil Conflict
}

\author{
Scott Gates \\ Håvard Hegre \\ Håvard Mokleiv Nygård \\ Håvard Strand
}

October 26, 2010

The findings, interpretations, and conclusions expressed in this paper are entirely those of the authors. They do not necessarily represent the views of the World Development Report 2011 team, the World Bank and its affiliated organizations, or those of the Executive Directors of the World Bank or the governments they represent. 


\title{
Consequences of Civil Conflict*
}

\author{
Scott Gates, Håvard Hegre, Håvard Mokleiv Nygård \& Håvard Strand
}

October 26, 2010

\section{Executive Summary}

This paper reviews the literature on the development consequences of internal armed conflict and state fragility and analyzes the relationship using data from World Development Indicators, UCDP/PRIO Armed Conflict Data, and World Bank state fragility assessments. Our main focus is on a set of development indicators that capture seven of the Millenium Development Goals, but we also look briefly into the effect of conflict and fragility on growth, human rights abuses, and democratization. We analyze these relationships using a variety of methods - averages by conflict and fragility status; cross-sectional regression analyses of change in each indicator over the time frame for which we have data; fixed-effects regression analyses of the impact on each indicator for each five-year period 1965-2009; as well as occasional panel time series models and matching techniques.

The analyses leave no doubt that conflict, fragility and poor development outcomes are closely related - these problems largely occur in the same set of developing countries, most of which are located in Asia and Sub-Saharan Africa. Acknowledging the difficulty of analyzing the effect of conflict on a set of indicators that we know are also causally related to the onset of conflict, we still conclude that conflict and fragility at least exacerbate these pre-existing conditions. Conflict and fragility are indeed major obstacles to development for several indicators. The table summarizes our findings, indicator by indicator.

\begin{tabular}{|c|c|c|c|c|c|c|}
\hline \multirow[t]{2}{*}{ MDG } & \multirow[t]{2}{*}{ Label } & \multirow[t]{2}{*}{ Indicator } & \multicolumn{2}{|l|}{$\begin{array}{l}\text { Effect of } \\
\text { conflict }\end{array}$} & \multicolumn{2}{|l|}{$\begin{array}{l}\text { Effect of } \\
\text { fragility }\end{array}$} \\
\hline & & & Cross-section & Fixed-effects & Cross-section & Fixed-effects \\
\hline MDG 1 & Ending Poverty & Undernourishment & Detrimental & Detrimental & Detrimental & Unclear \\
\hline MDG 1 & and Hunger & Poverty Headcount & Detrimental & Detrimental & Detrimental & No effect \\
\hline MDG 1 & & Life expectancy & Detrimental & Detrimental & Detrimental & Detrimental \\
\hline MDG 1 & & GDP per capita & Detrimental & Detrimental & Detrimental & Detrimental* \\
\hline MDG 2 & Universal & Prim. Sch. Enrollment & Detrimental & Detrimental & Detrimental & Beneficial? \\
\hline MDG 2 & Education & Sec. Sch. Attainment & Detrimental & Unclear & Detrimental & Unclear \\
\hline MDG 3 & Gender Parity & Primary School ratio & Detrimental & Beneficial? & Detrimental & No effect \\
\hline MDG 3 & & Life expect. ratio & No effect & Unclear & No effect & No effect \\
\hline MDG 4 & Child Mortality & Infant Mortality & Detrimental & Detrimental & Detrimental & Detrimental \\
\hline MDG 4 & & Under-5 Mortality & Detrimental & Detrimental & Detrimental & Detrimental \\
\hline MDG 5 & Maternal Mort. & Birth Attendance & No effect & Unclear & Detrimental & Beneficial? \\
\hline MDG 6 & Combat AIDS & \% HIV positive & Beneficial? & Beneficial? & Beneficial? & No effect \\
\hline MDG 7 & Environmental & Access to Water & Detrimental & Detrimental & Detrimental & Detrimental \\
\hline MDG 7 & Sustainability & Access to Sanitation & No effect & Unclear & No effect & No effect \\
\hline
\end{tabular}

*:Estimated on growth in GDP per capita using OLS with panel-corrected standard errors.

${ }^{*}$ We thank the World Bank and the Norwegian Ministry of Foreign Affairs for support. We especially thank Gary Milante, Sarah Cliffe, Colin Scott, Lene Lind, and Nadia Piffaretti at the World Bank, and Olaf DeGroot and Tilman Brück at DIW, as well participants at a World Bank Brownbag Seminar, Households in Conflict Network Workshops (in Berlin and Lisbon), a Norwegian Ministry of Foreign Affairs workshop, and the Tinbergen meetings in Amsterdam. 


\section{Contents}

1 Introduction $\quad 4$

2 Methodology 5

2.1 Countries included in analysis . . . . . . . . . . . . . . . . . . 5

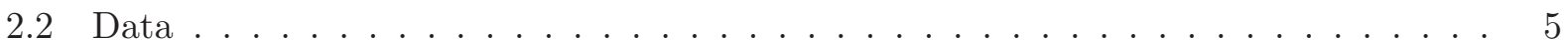

2.3 Conflict Country Categories . . . . . . . . . . . . . . . . . 7

2.4 Model Specification . . . . . . . . . . . . . . . . . . . . 7

2.4.1 Cross-sectional models . . . . . . . . . . . . . . . . . . . . . 9 9

2.4.2 Country Fixed-effects models . . . . . . . . . . . . . . . . . . 10

2.4 .3 Autocorrelation . . . . . . . . . . . . . . . . . . 11

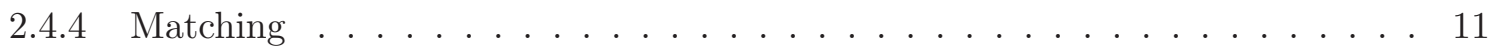

3 Overview of Effects of Conflict 12

3.1 Conflict, fragility, and gaps in development outcomes . . . . . . . . . . . . . 12

3.2 Is the gap caused by conflict and fragility? . . . . . . . . . . . . . . . . 21

3.3 Summary of results from our statistical analysis . . . . . . . . . . . . . . . 24

3.4 Conflict and the attainment of the Millennium Development Goals . . . . . . . . 28

4 Analysis of Individual Indicators $\quad 28$

4.1 MDG 1: Ending Poverty and Hunger . . . . . . . . . . . . . . 28

4.1 .1 Global Trends . . . . . . . . . . . . . . . . . . . 28

4.1.2 Literature on Effects of Conflict on Poverty and Hunger . . . . . . . . . . . . 29

4.1 .3 Empirical Analysis . . . . . . . . . . . . . . . . . . . . 32

4.2 MDG 2: Universal Education . . . . . . . . . . . . . . . . . . 40

4.2 .1 Global Trends. . . . . . . . . . . . . . . . . . . 40

4.2.2 Literature on Effects of Conflict on Education . . . . . . . . . . . . . . 41

4.2 .3 Empirical Analysis . . . . . . . . . . . . . . . . . . . . . . 42

4.3 MDG 3: Gender Parity . . . . . . . . . . . . . . . . . . . 44

4.3 .1 Global Trends . . . . . . . . . . . . . . . . . . . . . . . 44

4.3.2 Literature on Effects of Conflict on Gender Equality . . . . . . . . . . . . . . . 45

4.3 .3 Empirical Analysis . . . . . . . . . . . . . . . . . . 46

4.4 MDG 4: Infant Mortality Rates . . . . . . . . . . . . . . . . . 48

4.4 .1 Global Trends. . . . . . . . . . . . . . . . . . 48

4.4.2 Literature on Effects of Conflict on Infant Mortality . . . . . . . . . . . . . 49

4.4 .3 Empirical Analysis . . . . . . . . . . . . . . . . . . . . 49

4.5 MDG 5: Maternal Mortality/Birth Attendance . . . . . . . . . . . . . 51

4.5.1 Global Trends. . . . . . . . . . . . . . . . . . 51

4.5.2 Literature on Effects of Conflict on Maternal Mortality . . . . . . . . . . . 52

4.5.3 Empirical Analysis . . . . . . . . . . . . . . . . . . 53

4.6 MDG 6: Combat HIV/AIDS . . . . . . . . . . . . . . . . 54

4.6 .1 Global Trends. . . . . . . . . . . . . . . . . . 54

4.6 .2 Literature on Effects of Conflict . . . . . . . . . . . . . 55

4.6 .3 Empirical Analysis . . . . . . . . . . . . . . . . . . . 55

4.7 MDG 7: Environmental Sustainability . . . . . . . . . . 56 
4.7 .1 Global Trends . . . . . . . . . . . . . . . . . 56

4.7.2 Literature on Effects of Conflict . . . . . . . . . . . . . . . . 58

4.7 .3 Empirical Analysis . . . . . . . . . . . . . . . . . . . 59

$\begin{array}{lr}\text { A Appendix } & \mathbf{6 4}\end{array}$

A.1 List of countries . . . . . . . . . . . . . . . . . . . . 64

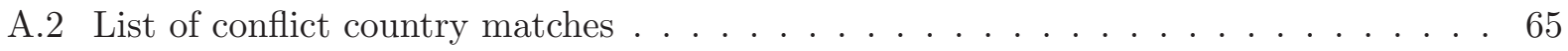

A.3 Regression Results . . . . . . . . . . . . . . . . . . 66

A.3.1 MDG 1: Ending Poverty and Hunger . . . . . . . . . . . . . . 66

A.3.2 MDG 2: Universal Education . . . . . . . . . . . . . . . 71

A.3.3 MDG 3: Gender Parity . . . . . . . . . . . . . . . . 73

A.3.4 MDG 4: Child Mortality . . . . . . . . . . . . . . . . . 75

A.3.5 MDG 5: Maternal Mortality . . . . . . . . . . . . . 77

A.3.6 MDG 6: Combat HIV/AIDS . . . . . . . . . . . . . 79

A.3.7 MDG 7: Environmental Sustainability . . . . . . . . . . . . 81 


\section{Introduction}

War is a development issue. War kills, but its consequences extend far beyond direct deaths. In addition to battlefield casualties, armed conflict often leads to forced migration, refugee flows, and the destruction of societies' infrastructure. Social, political, and economic institutions are indelibly harmed. The consequences of war, especially civil war, for development are profound. This paper is a statistical analysis of the consequences of conflict. The effects of armed conflict are evaluated with respect to the achievement of the Millennium Development Goals; economic growth; the political institutions of a state; and human rights. The direct and indirect mechanisms through which violent conflict degrades population health are also evaluated.

In Section 2, we summarize our methodological choices and present our conflict data. Section 3 summarizes the results of our analysis. Section 4 analyzes the effects of internal armed conflict on the attainment of the individual Millennium Development Goals.

Not all the consequences of armed conflict have ever been measured, and some are not even measurable. Indeed, many consequences of armed conflict are not incorporated in our analysis, such as the increased number of young males with war experience; the accumulation of light weapons subsequently used in violent crime; traumatic experiences (Ringdal, Ringdal and Simkus 2008); erosion of trust and emergence of ethnic prejudice (Strabac and Ringdal 2008); and so on. Another burden difficult to measure is the environmental impact. Few indicators allow a systematic comparison of this burden. We show the detrimental effect of conflict on the accessibility of water and adequate sanitation facilities, which are indicators with a considerable environmental component. But other environmental outcomes are difficult to assess because the impact of war differs from

one place to another. In some countries, such as Cambodia and Liberia, conflict sets the stage for large-scale illegal logging; in other places, other aspects of environmental regulation break down; and elsewhere, unexploded ordinances is a major problem caused by armed conflict. Such problems (missing data or unmeasurable variables) make it especially difficult to systematically assess the economic, political, social, environmental, and health effects of conflict.

We show how civil war harms the achievement of most of the indicators for which we have data. The results are consistent across most of our indicators. This suggests that war is also detrimental 
for development outcomes for which we have not been able to do any quantitative analysis, but that are highly correlated with the indicators that we do look into.

\section{Methodology}

\subsection{Countries included in analysis}

In most of our analyses, we link conflict or fragility status to improvements in development indicators. We expect conflict and fragile states to have less improvement than countries that avoid these political problems. However, many of the indicators have a natural maximum: Primary education attainment cannot exceed 100\%; infant mortality rates (IMR) can hardly go below 5 per 1,000; and measures such as our democracy index have a fixed maximum. Many industrial countries have reached the maximum values for many indicators, and do not improve much beyond that level. Also, these countries have no armed conflict (or relatively limited conflicts such as the one in Northern Ireland). To avoid our analysis being affected by the non-improvement in these countries, we remove all (but one: South Africa) of the countries classified as industrialized in the first World Bank Development Report (World Bank 1978, p.77) and a few other countries that we regard as industrialized by the 1970s. ${ }^{1}$

\section{$2.2 \quad$ Data}

We alternate between three datasets in our analysis. Most of the outcome indicators are measured in five-year intervals, so most analyses are based on a dataset containing one observation for each country for each five-year period. However, for the growth and democracy indicators, we use a country-year design with one observation for each country for each year. For our cross-sectional analysis, we use a dataset with one observation per country.

The conflict data come from the Uppsala Conflict Data Program (UCDP), the most comprehensive, accurate, and widely used data source on global armed conflicts. The versions of these data we

\footnotetext{
${ }^{1}$ The industrial countries we exclude are Austria, Australia, Belgium, Canada, Denmark, Finland, France, Germany, Greece, Iceland, Ireland, Italy, Japan, Luxembourg, Netherlands, New Zealand, Norway, Portugal, Spain, Sweden, Switzerland, United Kingdom, and United States. We retain South Africa because only parts of it can be said to be fully industrialized. A complete list of countries included is found in Table A-1.
} 
used were backdated and adapted for statistical use in collaboration with PRIO and is referred to as the UCDP/PRIO Armed Conflict Data (Gleditsch et al. 2002; Harbom and Wallensteen 2009). UCDP defines armed conflict as a contested incompatibility that concerns a government and/or territory where the use of armed force between two parties, of which at least one is the government of a state, results in at least 25 battle-related deaths. A civil (or intrastate) conflict occurs between a government and a non-government party. This definition of armed conflict is becoming a standard in how conflicts are systematically defined and studied. In the gap table presented in Section 3, we restrict the definition to conflict that have accumulated 1,000 deaths over a multi-year period.

Updates to these data have been published annually in the report series States in Armed Conflict since 1987, in the SIPRI Yearbook since 1988, the Journal of Peace Research since 1993, and in the Human Security Report since 2005. The data were also used in the World Bank PRR Breaking The Conflict Trap (Collier et al. 2003). The World Bank co-funded the backdating of these data from 1946 to 1989.

We use three measures of amount of conflict in the preceding five-year period. The first, we call conflict, measures the number of years within the preceding five-year period with conflict in the country as recorded in the UCDP/PRIO dataset (Gleditsch et al. 2002). A country without conflict the previous period receives a score of 0 ; a country with only a one-year minor conflict, a score of 1 ; and a country with minor conflict in each of the five years is assigned a 5 . If the conflict was recorded as major (more than 1,000 battle-related deaths within a year), each year of conflict is counted twice. Thus, a country with five years of major conflict receives the maximum score of 10.

The second conflict measure we call battle deaths: the log of the count of battle-related deaths caused by fighting in the five years preceding the observation period. About $20 \%$ of the countryperiods in our dataset have conflicts. The median conflict period led to about 2,500 deaths. The most destructive conflict periods (in Afghanistan and Cambodia) caused over 200,000 deaths each.

In the cross-sectional analyses, we count the total number of years the country has been in either minor or major conflict over the time period analyzed.

We also estimate the effect of state fragility as coded in the IDA Fragile States Dynamic List. 
Countries are coded as fragile if they either host peacekeeping missions or have a low score on the World Bank's Country Policy and Institutional Assessment (CPIA) rate. Countries have low CPIA scores if their policies and/or institutions are weak in terms of economic management, structural policies, policies for social inclusion and equity, and public sector management and institutions. ${ }^{2}$ The variable has the value 1 if the country is regarded as fragile in at least one of the preceding five years, and the value 0 if it was not coded as fragile in any of these years.

\subsection{Conflict Country Categories}

In a number of figures, we present information classified by conflict country category. We group countries into three categories: countries that have had no conflict between 1980 and 2008 (nonconflict), countries that had at least one year of conflict in the 1981-1990 period but no conflicts thereafter (post-conflict), and countries that had conflicts during the 1991-2008 period (conflict).

For the gap tables (Tables 1 and 4) we classify countries into four mutually exclusive categories.

\subsection{Model Specification}

We present three types of analyses of the relationships among conflict, fragility, and our outcome variables. First, we look at simple comparisons between countries within each conflict country category. Most earlier studies of the effects of conflict on development outcomes use this methodology. We also compare indicators such as the percentage of the population that suffers from undernourishment for countries with conflict with the same indicators for countries without conflict. Figure 1

\footnotetext{
${ }^{2}$ More precisely, states are coded as fragile in years where they:

1. For observations for years $t=2004-2008$ : have $\mathrm{CPIA}_{t}<3.2$

2. For years $t=1978-2003$ : have CPIA $_{t}<($ Standardized CPIA Cutoff for year $t)$. The cutoff is calculated as the Average CPIA $+($ Z-score*Standard Deviation (CPIA) $)$ where Z-score $=(3.24-($ Sample Averages for 2005 - 2009 /(Sample Standard Dev. 2005 - 2009 ))

3. For all years: Have an ongoing international or regional peacekeeping or political (non-border) mission, including special SRSG friends of political missions.

4. Are low-income countries without a CPIA score.

We use the harmonized list of fragile situations. A country is eligible to graduate out of fragility when $\mathrm{CPIA}_{t}>$ Cutoff and it has not qualified in any other way for the previous three years. This rule works in reverse as well: A country only relapses into fragility if it has a $C P I A<$ Cutoff for three years or meets other criteria above or below. Countries which are non-IDA before they join IDA but are fragile once they join IDA (or receive a CPIA score) are coded as fragile in the years preceding.
} 
exemplifies this analysis by showing the distribution of undernourishment for conflict, post-conflict, and non-conflict countries (Undernourishment by Conflict) and the corresponding distribution for fragile versus non-fragile states (Undernourishment by Fragility). ${ }^{3}$

Figure 1: The Percentage of Population Suffering from Undernourishment, By Conflict Status and State Fragility in 2005

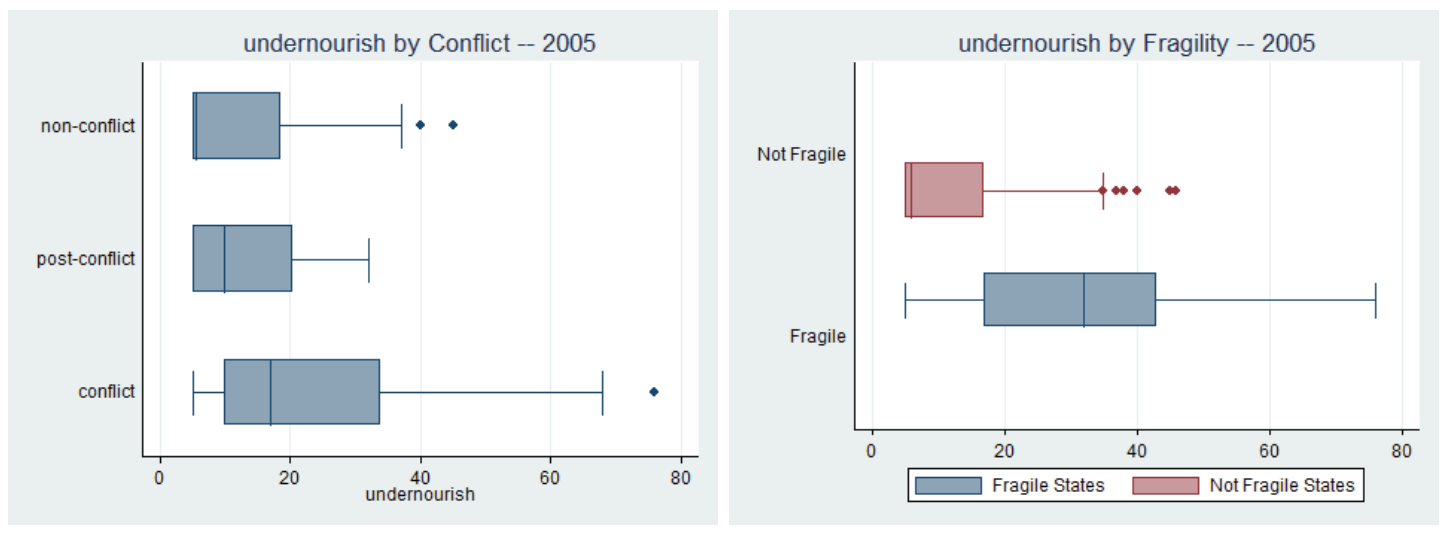

The box plots show clearly that populations in conflict countries on average suffer more from undernourishment than those in non-conflict countries, and that post-conflict countries are located between the two. However, this method is problematic methodologically, since it is not certain that these differences are caused by conflicts. Undernourishment is closely associated with other aspects of underdevelopment. Most conflict studies confirm that development, as measured by GDP per capita or energy consumption per capita, is among the most robust predictors of civil war (Hibbs 1973; Hegre et al. 2001; Fearon 2003; Collier et al. 2003; Hegre and Sambanis 2006). Underdevelopment in a general sense clearly facilitates both the occurrence of conflict and of undernourishment. It is necessary to account for these factors to avoid attributing development effects to factors that tend to cause conflicts in the first place.

We estimate three types of statistical models that attempt to account for this problem. The first type is a set of cross-sectional models where the dependent variable is the improvement from the first to the last observation for each country. The second is a set of fixed-effects models. We

\footnotetext{
${ }^{3}$ The median value in each group is given by the vertical line inside the box in the center of each box-whisker combination. The outer values of this box are the 25 th and 75 th percentiles. The whiskers represent the 'adjacent values' (Tukey 1977) - the upper adjacent value is the largest value smaller than $x_{75}+\frac{3}{2}\left(x_{75}-x_{25}\right)$. The dots are extreme observations outside the adjacent values.
} 
also estimate some models that take auto-correlation into account. Finally, we have estimated most models using matching techniques. We do not report the results from the matching models here. In most cases, they yield results that are consistent with the fixed-effects models.

\subsubsection{Cross-sectional models}

The dependent variable in our cross-sectional models (for example, Table A-3) is the improvement within each country between the first and the last non-missing observation for each of the MDG indicators. In other words, we examine changes in the gap between countries that are in conflict and that not in conflict, as well as between fragile and non-fragile states. The models include three control variables. The first is exposure - the number of years over which the improvement is measured. For some indicators, we have data from the 1960s to 2007 or 2008; for others, only a decade or so. Most countries have reduced problems, such as undernourishment and infant mortality, over time, and this improvement is likely to be larger the longer the period we analyze. The second control variable, '(firstnm) ...', is the value for the indicator for the first year. Countries that were very poor at the outset of the period may improve more than countries that were rich. The third control variable is log population size. Our models also include a set of region indicator variables.

We measure conflict with three different operationalizations. The first column in each of these tables reports the results from the first, which consists of the variables war and minor. These two variables count the number of years that the country in question has seen either war $(1,000+$ persons killed per year in battle-related situations) or minor armed conflict (more than 25 persons killed per year but less than 1,000). The second reports the total number of battle-related fatalities over the period. The third column is the log of battle deaths accumulated over the observation period.

In the fourth column of each cross-sectional analysis table we estimate a model with the fragility indicator as well as for the CPIA score alone. 


\subsubsection{Country Fixed-effects models}

Cross-sectional analysis of improvement (that is, closing the gap) accounts for some of the factors that affect both the development outcome and the risk of internal armed conflict. To handle this problem more systematically, we follow Iqbal (2010), arguably the most comprehensive and sophisticated study of the health consequences of conflict, in using fixed-effects regression models. These models remove between-countries differences in the outcome variables and concentrate on the within-country effects. If conflicts increase undernourishment, we should observe an increase relative to the country's average levels in the indicator during the conflict or in the period following the conflict. The fixed-effects models estimate the systematic within-country effect of conflicts.

Fixed-effects models may overprotect against such omitted-variable bias. In particular, countries that have had conflicts constantly over the entire period for which we have data will not contribute much to the estimated effect of conflict - conflict is then largely part of the fixed effect itself. Since these countries are also likely to be the most severely affected by conflict, a fixed-effects model may yield too-conservative estimates. This is accentuated by having data only for relatively short periods. Some countries may be poor when our data series start (typically at some year from 1970 to 1990) because of conflicts they have had before then. Our models will also ignore this effect.

Still, we choose to present a set of conservative estimates. For some indicators, this probably prevents us from identifying an effect of conflict. For other indicators we find substantial detrimental effects of conflict despite these limitations. This is particularly true for indicators for which we have long time series.

Time trends Most indicators have trends that show improvement in the MDG indicators. Given these strong trends, conflict countries may also improve the general situation in the country. To account for such trends, we include dummy variables for each five-year period in the fixed-effects models. 


\subsubsection{Autocorrelation}

Subsequent observations for the same country may be dependent on each other. To account for this, we also estimate a set of population-averaged models with an $\mathrm{AR}_{1}$ correlation model for the error terms within each country.

\subsubsection{Matching}

While the fixed-effects approach effectively eliminates any omitted-variable bias from countryspecific variables such as culture and geography, fixed-effects models cannot account for unobserved variables that vary over time. An alternative approach is matching (Ho et al. 2007). In a fully randomized experiment, the effect of a given variable can be gauged directly. By matching observations, we approach the experimental situation with real-world data. In our case, we want to match particular observations of countries that have had conflict with otherwise similar countries that have not had conflict, and then observe how these countries differ as an effect of the conflict.

The literature on matching has not converged towards a single best practice for a given problem (Hill 2008). Given the relative complexity in the assessment of the underlying assumptions, we rely on the $R$ MatchIt package (Ho et al. 2007). This package alternates our dataset to create a better balance between our conflict and non-conflict samples, and provides accessible verification of the post-hoc compliance with our model's assumptions. Following Iacus, King and Porro (2009), we employ a Coarsened Exact Matching (CEM) model. In exact-matching models, balance is sought by matching all units with the exact same value on explanatory variables, thereby forming subclasses that, in turn, should differ only with respect to the treatment variable (here, the treatment is the occurrence of conflict). Exact matching lends itself poorly to continuous explanatory variables such as the number of battle deaths over the last five years. CEM solves this problem by recoding the continuous variables into categorical variables and then applying the exact matching formula. This

method is superior to distance-oriented models (Abadie and Imbens 2006) since it effectively limits how different a matched pair can be.

Having produced a fairly balanced set of matches, the need for control variables is effectively removed. Ideally, all observations within a match strata, except for the treatment, should be 
similar. Although this would be the case with an exact matching design, the recoding of the CEM procedure retains some imbalance, justifying the inclusion of control variables. Following Blackwell et al. (2009) we estimate the sample average treatment effect on the treated unit through an OLS regression with CEM weights applied.

Using this technique, we have created a set of matched pairs, which allows us to compare countries that experience conflict and those that did not. The matching is done on the basis of the countries' values for population, GDP per capita, education levels, and ethnic fractionalization. (See Table A-2. Note that the list does not include all conflict countries - the CEM routine excludes cases where no match can be located.

\section{Overview of Effects of Conflict}

\subsection{Conflict, fragility, and gaps in development outcomes}

We analyze the effect of conflict on seven Millennium Development Goals, represented by 14 different indicators. There is no doubt that conflict countries and fragile states have less-favorable scores for all of these indicators. ${ }^{4}$ To illustrate these differences, we have grouped the world's developing countries into five groups according to their status over the 2003-2008 period: countries with armed conflicts causing at least 1,000 battle deaths (conflict countries); fragile countries without ongoing conflict (fragile states); countries that do not have ongoing conflicts and are not fragile, but have been so in at least one of the preceding 10 years (post-fragile/post-conflict); India and China as a separate category; and countries that have neither had conflicts nor been fragile in any of the 11 years from 10 years ago to the current year (other countries). ${ }^{5}$ The world map in Figure 2 shows the classification. Conflict and fragile states are most common in Sub-Saharan Africa and in an Asian belt ranging from Turkey in the west to Papua New Guinea in the east.

Table 1 shows the inter-group gaps by summarizing the 14 MDG indicators separately for each of the six groups. Among the 146 developing countries in our dataset in 2008, 19 were in conflict, 22 were fragile but not in conflict, 17 post-conflict or post-fragile, 85 neither of these, and India,

\footnotetext{
${ }^{4}$ With the possible exception of prevalence of HIV/AIDS.

${ }^{5}$ See Section 2.2 for precise definitions of all categories.
} 
Figure 2: The Countries in the World as Classified in Table 1

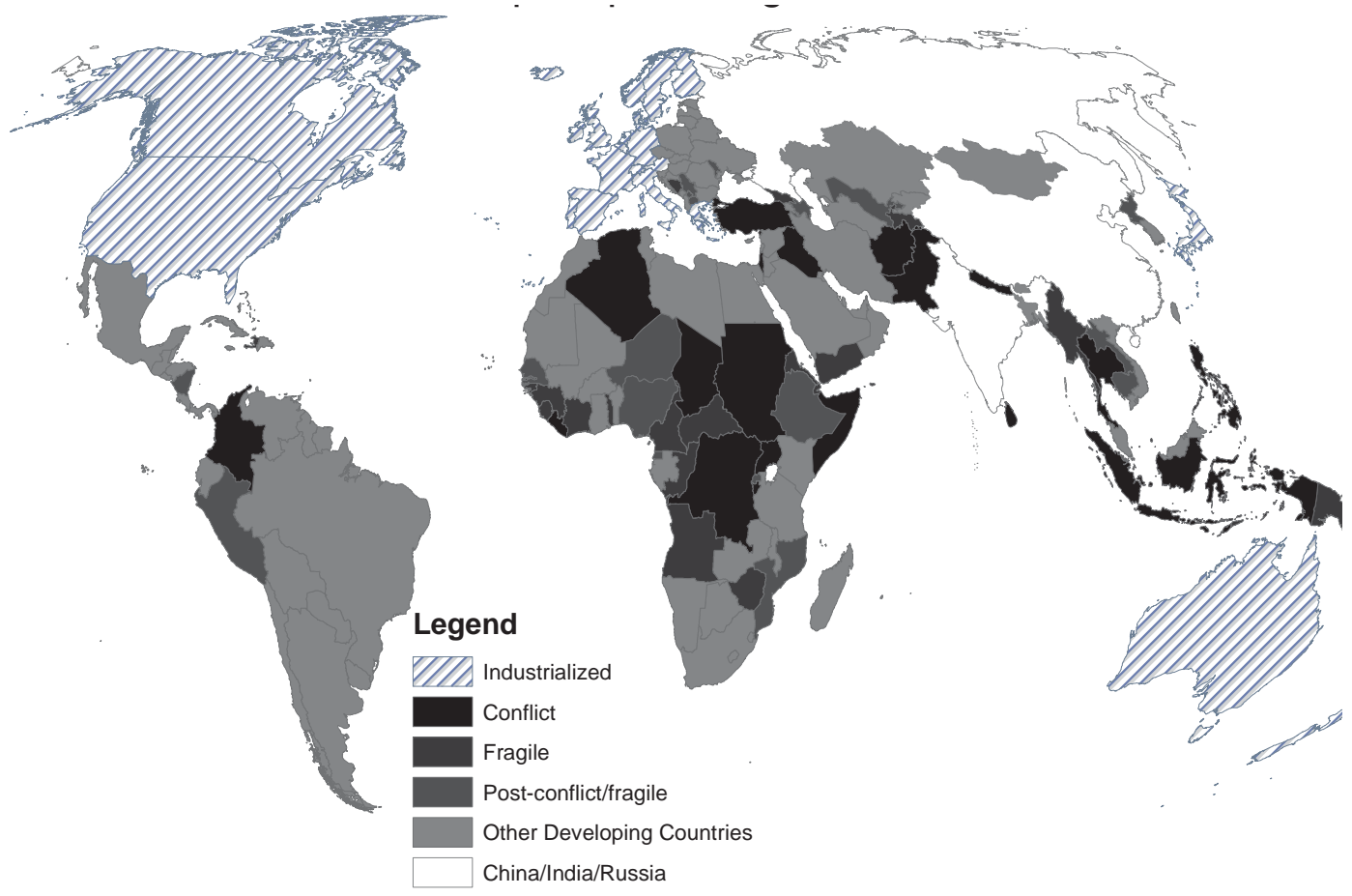

China, and Russia were treated as a separate group. We report the MDG indicators for the latest year for which we have sufficient data coverage. ${ }^{6}$ The first line in the table reports mean and median population size in each group. Notice that conflict countries are, on average, larger than those in other categories, and that fragile states are smaller. This is probably due to the strong correlations between fragility and risk of conflict on the one hand and population size and risk of war on the other. Most large, fragile states are likely to also have conflict and are therefore classified in the first group.

In Table 2 we show the similar gaps summarized over another set of groups: fragile states, postfragile states, other developing countries, and India/China/Russia. Among the 146 developing countries, 30 were fragile (some of them also in conflict), 14 post-conflict or post-fragile, and 99 neither of these.

It is clear from Tables 1 and 2 that conflict countries and fragile states perform worse than

\footnotetext{
${ }^{6}$ For several of the indicators, some countries have more recent data than the year indicated here. We have chosen to use a less recent time point if that gave us a considerably larger number of countries to analyze. For the demographic variables (infant mortality, population) we use UN estimates for 2008.
} 


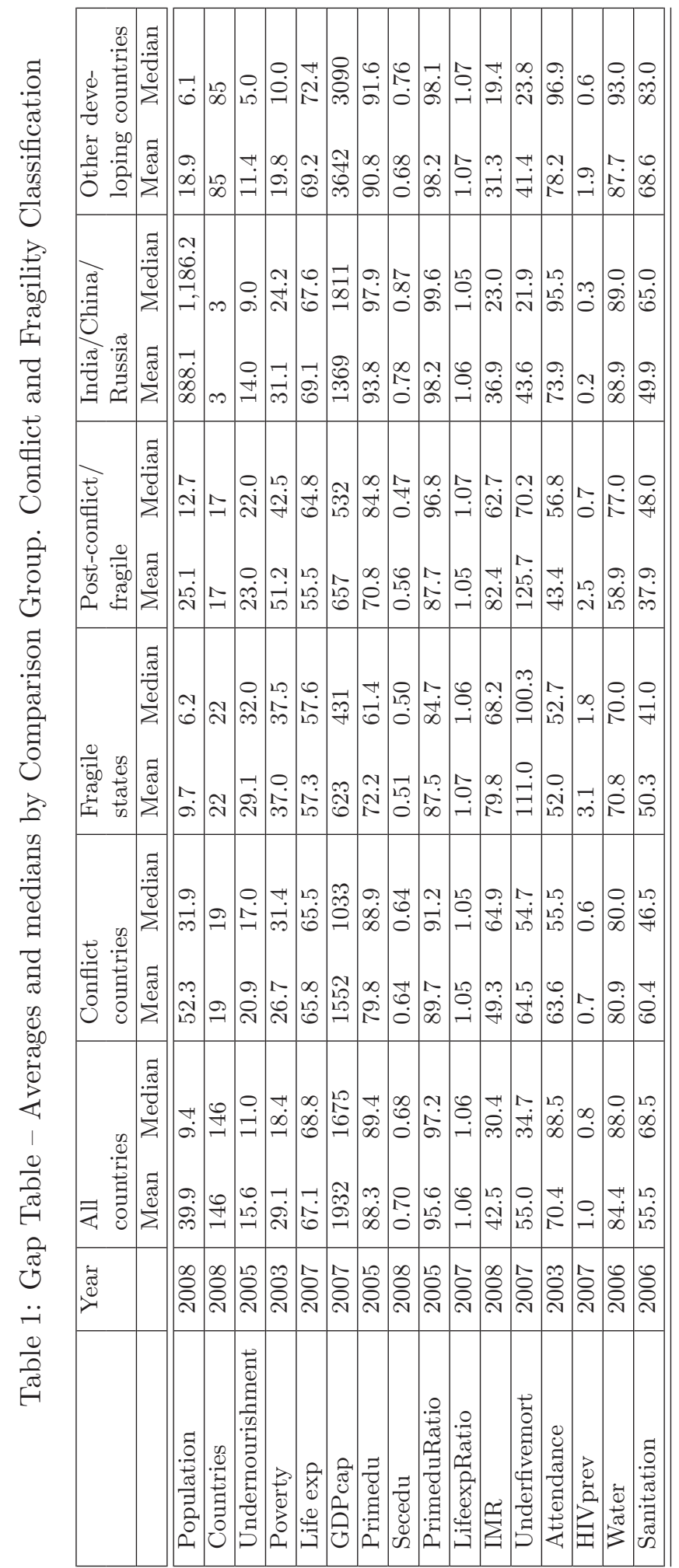


the other countries for most of the MDG indicators. Among fragile states, the mean proportion of populations undernourished is $29 \%$, as contrasted to $11 \%$ in other countries. In conflict countries, the average proportion undernourished is lower than in fragile states (about 19\%), which might be because state fragility is more detrimental to nourishment than overt armed conflicts are, but it might also be due to a size effect. Conflict countries are, on average, larger than non-conflict countries, and conflicts are often partly local and rarely affect the entire population in large countries (Buhaug and Gates 2002; Buhaug and Rød 2006; Raleigh et al. 2010). Measuring the effect of conflict using country-level indicators underestimates the local effect of conflict, in cases. On the other hand, the fragile states are predominantly small countries, and their fragility is likely to affect their entire population.

Comparing the mean and median values for the indicators is also instructive. For many indicators (for example, undernourishment, poverty, and HIV prevalence), the median value is considerably lower than the mean value in the other-countries group, suggesting a right-skewed distribution in this group (this is evident in the box plots in Figure 1). There are much smaller differences between the mean and median for the conflict country and fragile state groups. A minority of the non-conflict countries performs poorly in terms of the MDGs, but most of the conflict and fragile countries have poor development outcomes. Comparing median values is more appropriate in this case, because the median 'other country' is more typical than the mean within the category. Table 4 shows an even larger distance between this group of countries and the fragile states and conflict countries.

In Table 4, we have calculated the number of individuals affected for a subset of the MDG indicators. The first line reports the total population in 2008 in each of the five categories of developing countries. About 1.35 billion people live in conflict or fragile countries - about $20 \%$ of the population we study here. Among the 1.1 billion inhabitants in conflict countries, $19 \%$ are estimated to be undernourished, or 210 million people. About 30\% of the developing world's undernourished inhabitants live in fragile states or conflict countries.

In the tables that present the number of people affected, we present some of the indicators differently from the more traditional way we look at them other places in this paper. For MDG 2, 


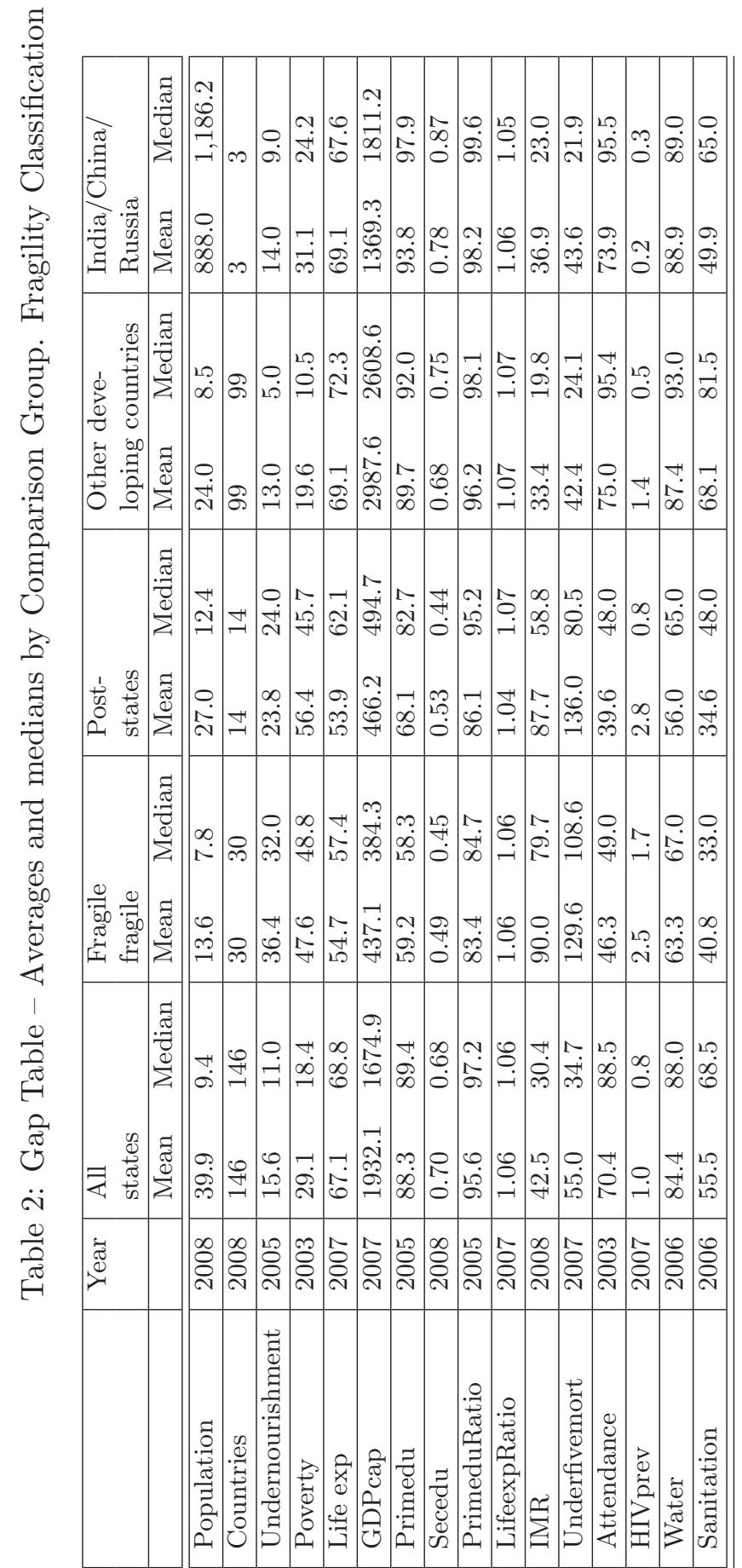




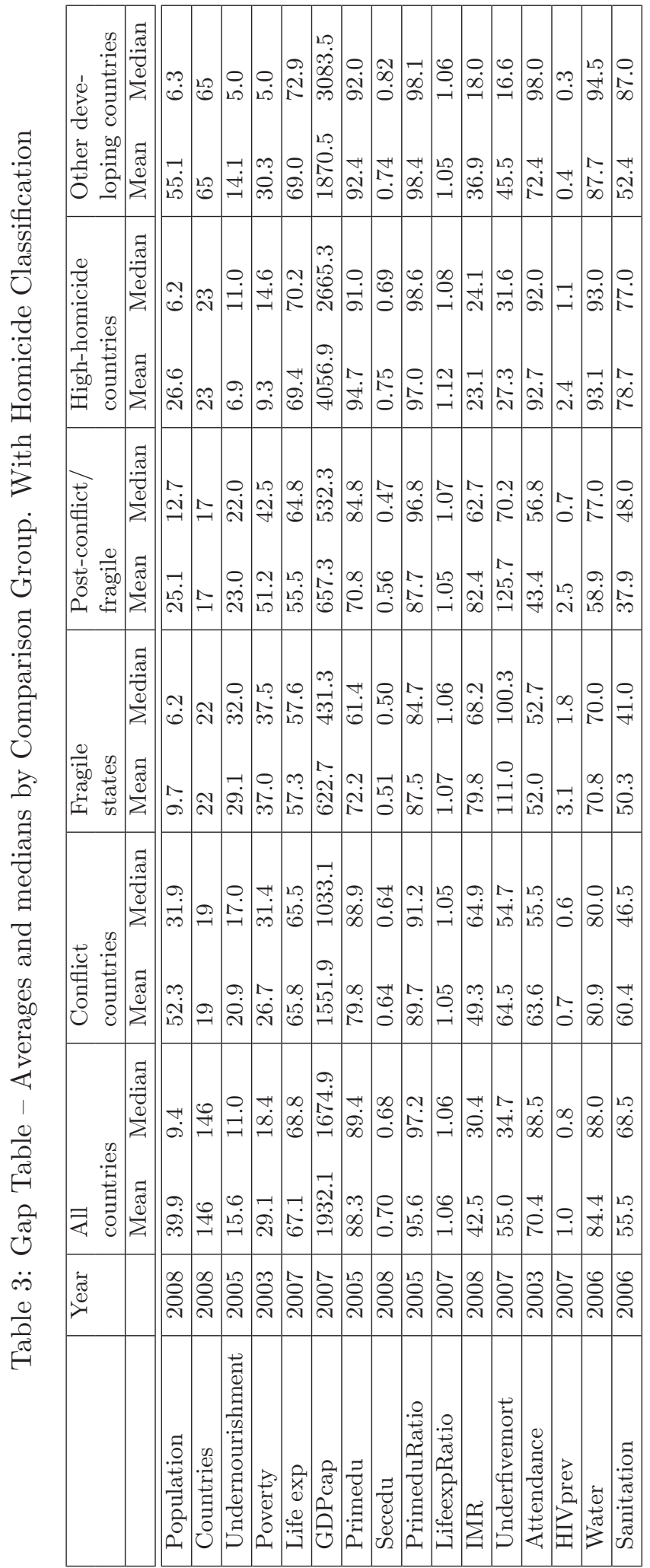


Table 4: Gap Table - Millions of people affected. Conflict and Fragility Classification

\begin{tabular}{|c|c|c|c|c|c|c|c|}
\hline & Year & $\begin{array}{r}\text { All } \\
\text { countries }\end{array}$ & $\begin{array}{r}\text { Conflict } \\
\text { countries }\end{array}$ & $\begin{array}{r}\text { Fragile } \\
\text { states }\end{array}$ & $\begin{array}{r}\text { Post-conflict/ } \\
\text { fragile }\end{array}$ & $\begin{array}{r}\text { India/China/ } \\
\text { Russia }\end{array}$ & $\begin{array}{l}\text { Other deve- } \\
\text { loping countries }\end{array}$ \\
\hline Population & 2008 & 5827.3 & 994.0 & 214.5 & 426.9 & 2664.3 & 1527.7 \\
\hline Countries & 2008 & 146 & 19 & 22 & 17 & 3 & 85 \\
\hline Undernourishment & 2005 & 909.2 & 207.8 & 62.4 & 98.0 & 373.8 & 173.9 \\
\hline Poverty & 2003 & 1694.8 & 265.2 & 79.2 & 218.5 & 828.4 & 302.6 \\
\hline No primary education & 2005 & 115.4 & 38.0 & 12.3 & 25.7 & 25.6 & 23.3 \\
\hline No secondar education & 2008 & 97.3 & 21.0 & 6.6 & 11.1 & 32.2 & 27.3 \\
\hline Infant mortality & 2008 & 4.8 & 1.1 & 0.4 & 0.9 & 1.6 & 0.9 \\
\hline Under-five mortality & 2007 & 31.0 & 7.3 & 3.1 & 7.2 & 9.6 & 6.0 \\
\hline No birth attendance & 2003 & 1723.7 & 361.4 & 102.9 & 241.6 & 696.5 & 332.5 \\
\hline HIV positive & 2007 & 56.2 & 7.1 & 6.6 & 10.7 & 6.5 & 29.4 \\
\hline Without water & 2006 & 908.4 & 189.5 & 62.6 & 175.4 & 294.9 & 187.3 \\
\hline Without sanitation & 2006 & 2594.6 & 393.9 & 106.5 & 265.2 & 1334.4 & 480.1 \\
\hline
\end{tabular}

Table 5: Gap Table - Millions of people affected. Fragility Only Classification

\begin{tabular}{|l|r|r|r|r|r|r|}
\hline & Year & $\begin{array}{r}\text { All } \\
\text { countries }\end{array}$ & $\begin{array}{r}\text { Fragile } \\
\text { states }\end{array}$ & $\begin{array}{r}\text { Post- } \\
\text { fragile }\end{array}$ & $\begin{array}{r}\text { Other deve- } \\
\text { loping countries }\end{array}$ & $\begin{array}{r}\text { India/China/ } \\
\text { Russia }\end{array}$ \\
\hline Population & 2008 & 5827.3 & 408.4 & 377.4 & 2377.2 & 2664.3 \\
\hline Countries & 2008 & 146 & 30 & 14 & 99 & 3 \\
\hline Undernourishment & 2005 & 909.2 & 148.5 & 89.7 & 309.1 & 373.8 \\
\hline Poverty & 2003 & 1694.8 & 194.3 & 212.8 & 467.0 & 828.4 \\
\hline No primary education & 2005 & 115.4 & 35.6 & 25.0 & 41.9 & 25.6 \\
\hline No secondary education & 2008 & 97.3 & 12.8 & 10.2 & 43.0 & 32.2 \\
\hline Infant mortality & 2008 & 4.8 & 1.1 & 0.9 & 1.6 & 1.6 \\
\hline Under-five mortality & 2007 & 31.0 & 7.6 & 7.1 & 9.9 & 9.6 \\
\hline No birth attendance & 2003 & 1723.7 & 219.2 & 228.0 & 593.4 & 696.5 \\
\hline HIV positive & 2007 & 56.2 & 10.2 & 10.5 & 34.5 & 6.5 \\
\hline Without water & 2006 & 908.4 & 149.8 & 166.2 & 300.1 & 294.9 \\
\hline Without sanitation & 2006 & 2594.6 & 241.9 & 246.8 & 758.3 & 1334.4 \\
\hline
\end{tabular}


for example, we present the percentage of children not enrolled in primary education, rather than the percentage that is. We do the same for secondary school non-attainment, births non-attendance, and lack of access to water and sanitation.

We calculate the number of children that do not attain primary education by first computing the total population in each age group for each conflict/fragility category and multiplying with the proportions affected (reported in Table 1). ${ }^{7}$ We estimate that 38 million out of about 230 million children in conflict countries and fragile states fail to attain primary education, or about 4 million children per year. About $30 \%$ of the children that fail to complete primary education live in these countries.

In Table 5, we show the number of people affected in each of the five-category variables that only classify countries in terms of fragility.

Table 6: Gap Table - Millions of people affected. Fragility Only Classification - including Pakistan and Kenya

\begin{tabular}{|l|r|r|r|r|r|r|}
\hline & Year & $\begin{array}{r}\text { All } \\
\text { countries }\end{array}$ & $\begin{array}{r}\text { Fragile } \\
\text { states }\end{array}$ & $\begin{array}{r}\text { Post- } \\
\text { fragile }\end{array}$ & $\begin{array}{r}\text { Other deve- } \\
\text { loping countries }\end{array}$ & $\begin{array}{r}\text { India/China/ } \\
\text { Russia }\end{array}$ \\
\hline Population & 2008 & 5827.3 & 613.9 & 377.4 & 2171.7 & 2664.3 \\
\hline Countries & 2008 & 146.0 & 32.0 & 14.0 & 97.0 & 3.0 \\
\hline Undernourishment & 2005 & 909.2 & 197.2 & 89.7 & 258.5 & 373.8 \\
\hline Poverty & 2003 & 1694.8 & 242.2 & 212.8 & 403.6 & 828.4 \\
\hline Primedu & 2005 & 115.4 & 49.3 & 25.0 & 30.2 & 25.6 \\
\hline Secedu & 2008 & 97.3 & 18.8 & 10.2 & 37.4 & 32.2 \\
\hline IMR & 2008 & 4.8 & 1.4 & 0.9 & 1.3 & 1.6 \\
\hline Underfivemort & 2007 & 31.0 & 9.9 & 7.1 & 7.8 & 9.6 \\
\hline Attendance & 2003 & 1723.7 & 330.0 & 228.0 & 484.2 & 696.5 \\
\hline HIVprev & 2007 & 56.2 & 9.9 & 10.5 & 34.5 & 6.5 \\
\hline Water & 2006 & 908.4 & 182.7 & 166.2 & 266.9 & 294.9 \\
\hline Sanitation & 2006 & 2594.6 & 334.2 & 246.8 & 664.9 & 1334.4 \\
\hline
\end{tabular}

\footnotetext{
${ }^{7}$ We base these estimates on data from United Nations (2007) that give countries' populations grouped in five-year intervals, e.g. 0-4 years, 5-9 years, etc. To calculate the population of primary school age, we add the 10-14 year population and $80 \%$ of the 5-9 year population. For secondary school enrollment, we use $60 \%$ of the 15-19 year population. For infant mortality, we use the population in the $0-4$ year category divided by 5 .
} 
Table 7: Gap Table - Millions of people affected. With-Homicide Classification

\begin{tabular}{|c|c|c|c|c|c|c|c|}
\hline & Year & $\begin{array}{r}\text { All } \\
\text { countries }\end{array}$ & $\begin{array}{r}\text { Conflict } \\
\text { countries }\end{array}$ & $\begin{array}{r}\text { Fragile } \\
\text { states }\end{array}$ & $\begin{array}{r}\text { Post-conflict/ } \\
\text { fragile }\end{array}$ & $\begin{array}{r}\text { High-homicide } \\
\text { countries }\end{array}$ & $\begin{array}{l}\text { Other deve- } \\
\text { loping countries }\end{array}$ \\
\hline Population & 2008 & 5827.3 & 994.0 & 214.5 & 426.9 & 612.3 & 3579.7 \\
\hline Countries & 2008 & 146 & 19 & 22 & 17 & 23 & 65 \\
\hline Undernourishment & 2005 & 909.2 & 207.8 & 62.4 & 98.0 & 42.2 & 506.5 \\
\hline Poverty & 2003 & 1694.8 & 265.2 & 79.2 & 218.5 & 57.2 & 1086.4 \\
\hline No primary education & 2005 & 115.4 & 38.0 & 12.3 & 25.7 & 5.0 & 43.6 \\
\hline No secondary education & 2008 & 97.3 & 21.0 & 6.6 & 11.1 & 8.5 & 50.9 \\
\hline Infant mortality & 2008 & 4.8 & 1.1 & 0.4 & 0.9 & 0.2 & 2.3 \\
\hline Under-five mortality & 2007 & 31.0 & 7.3 & 3.1 & 7.2 & 1.5 & 14.1 \\
\hline No birth attendance & 2003 & 1723.7 & 361.4 & 102.9 & 241.6 & 44.5 & 987.0 \\
\hline HIV positive & 2007 & 56.2 & 7.1 & 6.6 & 10.7 & 14.6 & 15.8 \\
\hline Without water & 2006 & 908.4 & 189.5 & 62.6 & 175.4 & 42.5 & 439.7 \\
\hline Without sanitation & 2006 & 2594.6 & 393.9 & 106.5 & 265.2 & 130.2 & 1703.2 \\
\hline
\end{tabular}

The relationship between conflict, fragility, and the failure to attain development goals is illustrated in Figure 3. In the Undernourishment map (on the left), countries that have rates of undernourishment above the average for the developing countries are highlighted - these countries can be said to be the main contributors to undernourishment in the world. The Infant Mortality map (on the right) shows the main contributors to infant mortality according to the same definition. The relationship to conflict and fragility appears from comparing these maps to Figure 2 - as for conflict and fragility, the main contributors are found in Sub-Saharan Africa and in a belt of Asian countries from Pakistan to Papua New Guinea.

Figure 3: Contributors to MDG deficit: Undernourishment and infant mortality rates
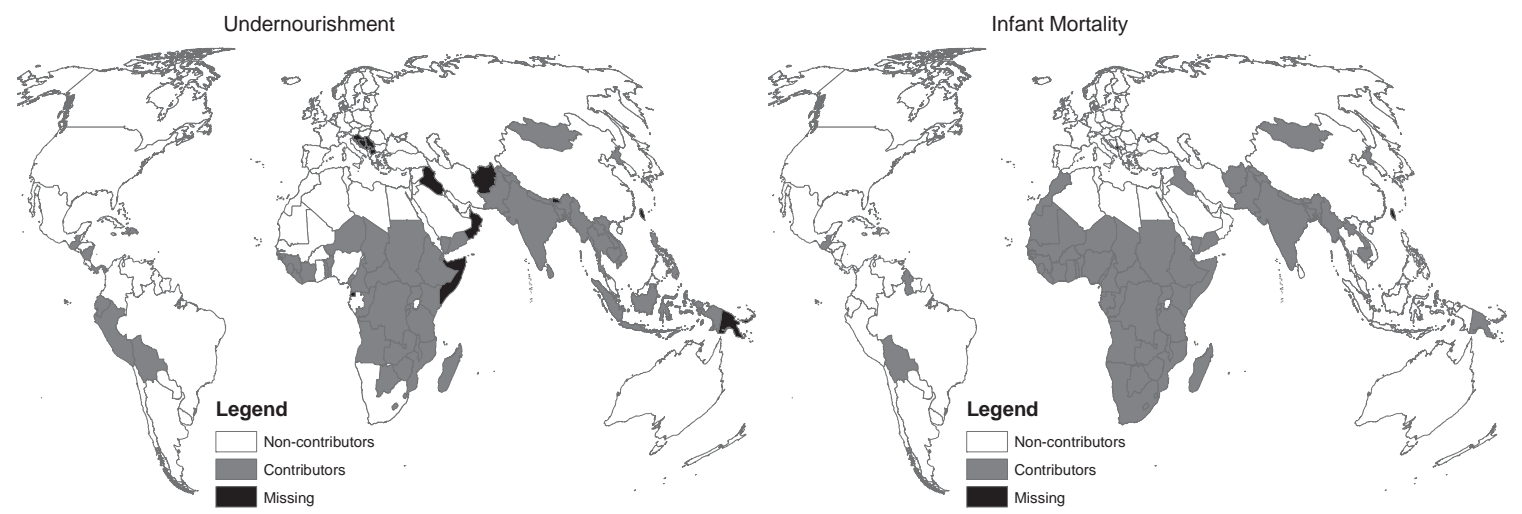

In Figure 4, we aggregate over all 14 indicators the information shown for the two indicators in Figure 3. This map shows the proportion of the 14 indicators for which the country has a 
worse than the average country. If a country is missing data for one or more of the indicators, the maps shows the proportion of indicators with data for which the country performs worse than the average. DRC, for instance, is worse than the average for all indicators for which we have data for that country.

Figure 4: Contributors to MDG deficit: All MDG indicators

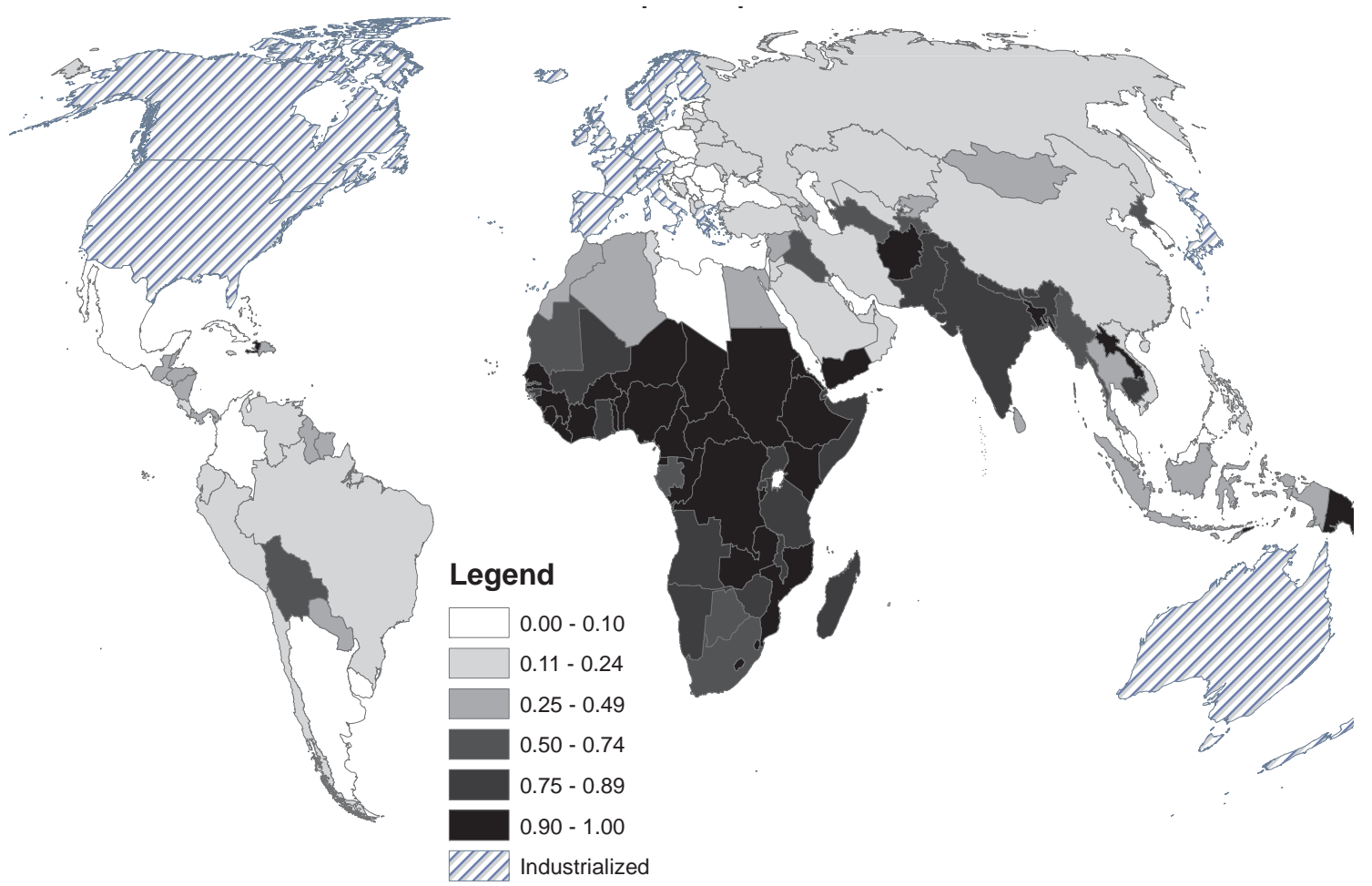

Although the overlap with the map of conflict and fragile states is not perfect, there are clear resemblances. Poor development outcomes are most common in Sub-Saharan Africa and in an Asian belt ranging from Iraq in the west to Papua New Guinea in the east.

\subsection{Is the gap caused by conflict and fragility?}

There are a number of good reasons to think that conflicts do have a causal, detrimental effect on these indicators. Ghobarah, Huth and Russett (2003, 191-192) suggest a useful theoretical framework for analyzing the effect of conflict and fragility on the development outcomes summarized in the MDGs. Noting that "health conditions are shaped by the interplay of exposure to conditions 
that create varying risks of death and disease for different groups in society and the ability of groups in society to gain access to health care and receive the full range of benefits produced by the health-care system", they first list four sources of differences in health outcomes:

1. The extent to which populations are exposed to conditions that increase the risk of death, disease, and disability

2. The financial and human resources available to address the public health needs of populations

3. The level of resources actually allocated to public health needs by the private and public sectors

4. The degree to which resources actually allocated to public health are efficiently used

The first source mainly affects the health-related MDGs (MDG 1, 4, 5, and 6), whereas the other three are equally relevant to the other outcomes we have analyzed.

Civil wars directly expose populations to conditions that increase mortality and disability, source 1 above. The most obvious is, of course, battle deaths. Mortality increases and life expectancy decreases through deaths incurred as a direct consequence of fighting. The effects of this mechanism on aggregate life expectancy and mortality levels depend on the technology of war used by the warring parties. Conflict characterized by low-scale guerilla warfare will produce many fewer battle deaths than conflict in which artillery shelling and aerial bombardment is used.

By and large, however, the indirect effects of conflict are likely to be much greater than the direct effects. This is not only true for intra-state wars. "For instance the influenza epidemic that spread in 1918 and 1919 killed more people than the deaths [that] resulted directly from military activity in World War I (...) some of the causes of the magnitude that epidemic reached included the mass movement of armed forces, the conditions in which soldiers lived in the trenches, and the effects of mustard gas and fumes generated by some weapons" (Iqbal 2010, 40). Civil wars also often displace large populations, and the temporary accommodations often expose them to new risk factors. As noted by Ghobarah, Huth and Russett (2003, 192), "epidemic diseases - tuberculosis, measles, pneumonia, cholera, typhoid, paratyphoid, and dysentery - are likely to emerge from 
crowding, bad water, and poor sanitation in camps, while malnutrition and stress compromise people's immune systems".

Even without displacement, conflict can destroy pre-existing local health facilities, as well as block access to proximate facilities because of the risks involved in traveling through conflict zones. This is particularly true for infant and under-five mortality and for birth-related maternal mortality. Epidemiological research argues that disease, especially diarrhea, has a greater effect on mortality rates than direct battle deaths. Degomme and Guha-Sapir $(2010,297)$ study Darfur and argue that "more than $80 \%$ of excess deaths were not a result of [the] violence. (...) but the main cause of mortality during the stabilization period were diseases such as diarrhoea". Such excess deaths result from an increased spread of disease, which drives up infant mortality rates. The increased spread of disease may be caused by the inability of states to provide health services for their population during wartime, or to conditions, such as in refugee camps, that increase the transmission of disease. Ghobarah, Huth and Russett $(2003,192)$ further note that other forms of violence often escalate in the aftermath of war, adding to the mortality and disability rates. Civil wars also affect the second and third sources. Widespread violence and physical destruction disrupts transportation, cutting rural populations off from health and education facilities. Civil war leads to diversion and dissaving effects (Collier 1999): Military expenditures invariably increase during war, reducing funds available to promote public health, education, poverty alleviation, and so on. (Gleditsch 1996; Knight, Loayza and Villanueva 1996). Local economies may be disrupted, partly because of disincentives to invest at all, partly because of capital flight (Collier 1999); the effect is a reduction of public spending. Local effects can be much more severe than national effects: When distinct population groups are perceived as the opposition, the government will often be tempted to cut off public spending in their territory at the same time as the military contest is likely to be most intense in the opposition's home region.

State fragility is, by our definition, partly associated with the same point. Countries receive low CPIA scores if they are weak in terms of inter alia economic management; policies for social inclusion and equity; and public sector management. Such weakness is likely to be manifested in inadequate investment in public health infrastructure. 
Finally, conflict reduces the efficiency of the public health resources that are allocated. Again in the words of Ghobarah, Huth and Russett (2003, 193), "Wartime destruction and disruption of the transportation infrastructure (roads, bridges, railroad systems; communications and electricity) weakens the ability to distribute clean water, food, medicine, and relief supplies, both to refugees and to others who stay in place." Medical personnel tend to leave conflict zones if they can, leaving the poorest and most immobile behind. Ghobarah et al. note that military forces often deliberately target health facilities and transportation infrastructure to weaken the opposition.

Fragility, defined as weakness in institutions, is obviously also associated with low efficiency in the use of public health expenditures.

To what extent can these mechanisms be traced empirically?

\subsection{Summary of results from our statistical analysis}

Table 8 lists the MDGs and the various indicators we analyze to gauge the causal effect of conflict on goal attainment. The detailed results are discussed in Section 4 and reported in Appendix A. Two columns in the table summarize the effect of conflict - as estimated in cross-sectional analyses (column 4) and in fixed-effects regression models (column 5). The two right-most columns (Effect of Fragility) report the same for the fragility variable.

Table 8: Summary of Regression Results, Millenium Development Goals

\begin{tabular}{|c|c|c|c|c|c|c|}
\hline \multirow[t]{2}{*}{$\mathrm{MDG}$} & \multirow[t]{2}{*}{ Label } & \multirow[t]{2}{*}{ Indicator } & \multicolumn{2}{|l|}{$\begin{array}{l}\text { Effect of } \\
\text { conflict }\end{array}$} & \multicolumn{2}{|l|}{$\begin{array}{l}\text { Effect of } \\
\text { fragility }\end{array}$} \\
\hline & & & Cross-section & Fixed-effects & Cross-section & Fixed-effects \\
\hline MDG 1 & Ending Poverty & Undernourishment & Detrimental & Detrimental & Detrimental & Unclear \\
\hline MDG 1 & and Hunger & Poverty Headcount & Detrimental & Detrimental & Detrimental & No effect \\
\hline MDG 1 & & Life expectancy & Detrimental & Detrimental & Detrimental & Detrimental \\
\hline MDG 1 & & GDP per capita & Detrimental & Detrimental & Detrimental & Detrimental* $^{*}$ \\
\hline MDG 2 & Universal & Prim. Sch. Enrollment & Detrimental & Detrimental & Detrimental & Beneficial? \\
\hline MDG 2 & Education & Sec. Sch. Attainment & Detrimental & Unclear & Detrimental & Unclear \\
\hline $\begin{array}{l}\text { MDG } 3 \\
\text { MDG } 3\end{array}$ & Gender Parity & Primary School ratio & Detrimental & Beneficial? & Detrimental & No effect \\
\hline $\begin{array}{l}\mathrm{MDG} 3 \\
\mathrm{MDG} 4\end{array}$ & Child Mortality & Lire expect. ratio & No effect & lear & No effect & effect \\
\hline MDG 4 & 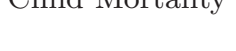 & Under-5 Mortality & Detrimental & Detrimental & $\begin{array}{l}\text { Detrimental } \\
\text { Detrimental }\end{array}$ & $\begin{array}{l}\text { Detrimental } \\
\text { Detrimental }\end{array}$ \\
\hline MDG 5 & Maternal Mort. & Birth Attendance & No effect & Unclear & Detrimental & Beneficial? \\
\hline MDG 6 & Combat AIDS & \% HIV positive & Beneficial? & Beneficial? & Beneficial? & No effect \\
\hline MDG 7 & Environmental & Access to Water & Detrimental & Detrimental & Detrimental & Detrimental \\
\hline MDG 7 & Sustainability & Access to Sanitation & No effect & Unclear & No effect & No effect \\
\hline
\end{tabular}

*:Estimated on growth in GDP per capita using OLS with panel-corrected standard errors. 
As the table indicates, we find clear detrimental effects of conflict on the reduction of poverty and hunger, on primary education, on the reduction of child mortality, and on access to water. In the cross-section analyses we also find a detrimental effect on secondary education and on gender parity measured in the female-to-male primary education attainment ratio.

We find clear detrimental effects of conflict on the reduction of poverty and hunger, on primary education, on the reduction of child mortality, and on access to water. In the cross-sectional analyses we also find a detrimental effect on secondary education and on gender parity measured in the female-to-male primary education attainment ratio. As we will discuss, these effects are quite strong. For example, five years of sustained conflict with only a moderate amount of direct fatalities, on average, push 3\%-4\% of the population into undernourishment. We also find that conflicts generate surplus infant mortality at the same level as the direct deaths - for every soldier killed in battle, one infant dies that would otherwise have survived the indirect effects of conflict.

We find very limited evidence that conflict affects gender parity, measured as the female-to-male life expectancy ratio. Internal conflicts seem to harm males and females in equal measures. We find no effect of conflict on access to sanitation facilities. Finally, our empirical analysis indicates, if anything, that conflicts tend to limit the spread of HIV/AIDS, adding to the inconclusiveness of other studies (for example, Spiegel et al. 2007). This is possibly because of the relative short time horizon in our study. In the short term, populations may be less mobile and interact less with each other, limiting contamination (and certainly diagnosis). We do not assess the long-term nor the spatial effects, however. The HIV virus has a long incubation period, and conflict may delay reporting or detection of HIV positive individuals. A recent study (Iqbal and Zorn 2010) finds clear detrimental effects of conflict on HIV/AIDS prevalence.

The effects of fragility are somewhat less clear. The cross-sectional analyses indicate a detrimental effect on most of the MDG indicators, except for female-to-male life expectancy ratio, HIV/AIDS prevalence, and access to sanitation. In the more conservative fixed-effects models, however, fragility has a clear detrimental effect only on life expectancy, growth, infant and underfive mortalities, and access to safe water. We have also estimated the relationship between the CPIA score and the development outcomes in a set of fixed-effects models. These analyses yield 
clear results only for one indicator - good governance, as measured by the World Bank, increases life expectancy. For other indicators, results are inconclusive. The inconclusiveness of the CPIA component of the fragile-state indicator suggests that the conflict component of the fragility indicator is more important than the governance component.

Section 4 also presents a number of trend graphs, some of which indicate beneficial effects of conflict. This probably reflects conflict countries and fragile states being among the most underdeveloped in 1990. Together with others of the poorest countries, they have partly closed the gap to the more developed countries. The cross-sectional analyses show, however, that conflict countries improve at a slower pace than other countries that started at the same level in 1990.

Because of having fairly short time series and available data only for every five years, we have not been able to assess the extent to which the detrimental effects linger on after the conflict or fragility period. This has been possible for GDP per capita, however, and given the strong correlation between economic production and most of the MDG outcomes, this should indicate the extent to which the effect of conflict becomes permanent.

Figure 5: Simulated change in GDP per capita 1970-2000, for conflict and non-conflict country, long war (1974-86) and short war (1974-78)
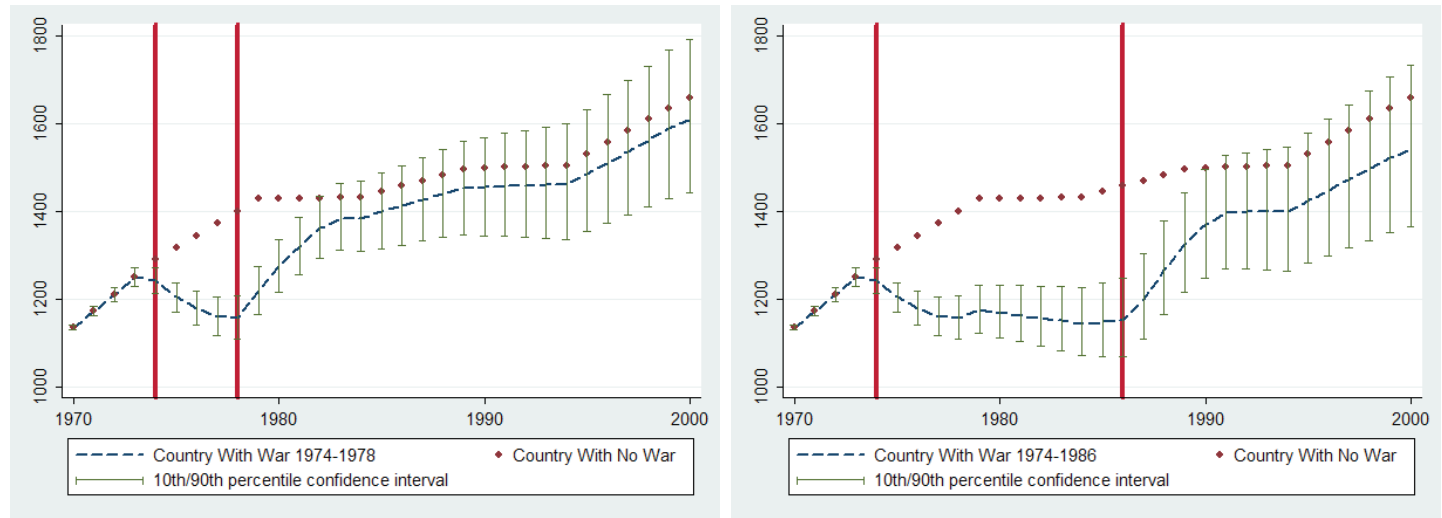

Figure 5 shows simulated GDP per capita for the 1970-2000 period for a country that started out at 1,100 dollars per capita, about the level of Algeria in 1970. The dotted lines in the two sub-figures show the average growth trajectory for non-conflict developing countries. By regression models we have estimated the difference in growth rates from this average for countries that were at conflict at $t, t-1, t-2$, and so on. The results from the regression model are given in Table A-31. 
The dashed lines indicate the growth trajectory for the same countries if they experience conflict.

The left panel shows expected GDP per capita for a country with war (more than 1,000 battle deaths per year) that broke out in 1974 and lasted for five years until 1978, with peace thereafter. This figure shows that the growth loss over the first five years of the conflict is very large - about $20 \%$ relative to the non-conflict country. The estimates indicate that countries see an immediate pick-up in growth after conflicts of this duration. The right panel simulates a country that had an outbreak of war in 1974 that lasted for 13 years up to 1986. After 10 years of conflict, there are some signs of conflict countries recovering parts of the war losses, and this continues in the first five years of the post-conflict period. Five years after the conflict ended, we cannot discern further pick-up growth in either of the scenarios. The aggregate pick-up growth up to then is, on average, not sufficient to close the gap caused by the conflict. The median-conflict country is almost $10 \%$ under the trajectory it would have followed without the conflict. There are some uncertainties in these estimates - the probability that the conflict country closes the gap to the non-conflict country is larger than $10 \%$. But the probability that the aggregate growth loss is as large as $20 \%$ is also larger than $10 \%$.

In a series of analyses not shown here, we have attempted to estimate the time it takes for countries to recover from the effects of civil war or fragility. Figure 5 shows results for GDP per capita, an indicator for which we have annual data and long time series. Our analysis shows that, on average, countries recover partly over a five-year period, but we are not able to find evidence for much recovery beyond this point. ${ }^{8}$ For other indicators we have not been able to estimate recovery in a similar fashion, partly because we only have data for five-year periods, and, for most indicators, data for shorter periods. This problem is compounded by the fact that variables such as education enrollment and infant mortality rates take longer to respond to changed environments than GDP per capita.

\footnotetext{
${ }^{8}$ This is partly because of the methodological problems involved in tracing effects over long time spans with data for only four decades, with most post-conflict periods occurring in the last 15 years.
} 


\subsection{Conflict and the attainment of the Millennium Development Goals}

It is evident from this analysis that internal armed conflict and state fragility hamper development. Nourishment, infant and maternal mortality, education attainment, and other goals improve at a considerably higher rate in countries that avoid conflict. Unfortunately, conflict is most frequent in poor, underdeveloped countries - this is the conflict trap (Collier et al. 2003) in which conflict creates underdevelopment that in turn, engenders conflict. If the conflict trap cannot be broken, the world will continue to diverge between successful developers and 'the bottom billion' (Collier 2007).

We then turn to a more detailed discussion of the impact of conflict on the individual millenium development goals.

\section{Analysis of Individual Indicators}

\subsection{MDG 1: Ending Poverty and Hunger}

\subsubsection{Global Trends}

Figure 6 shows the trends in prevalence of undernourishment during the years 1990-2008 for the three conflict categories and the two state-fragility categories. The countries that had no conflicts (non-conflict: the dashed line) in the period 1980-2008 have a slowly decreasing undernourishment rate. The countries that had conflict after 1990 (conflict: the solid line) start with a much higher rate of undernourishment in 1990 (at about $28 \%$ as compared to $12 \%$ ) but decrease steadily. The countries that had conflict during the 1980s but not after (post-conflict: -the dotted line) had undernourishment rates at close to $20 \%$, but this rate rapidly decreases toward the non-conflict countries over the next 18 years.

Figure 7 shows the distribution in 2005 for the countries in each category. In addition to showing that most non-fragile states are better nourished than the fragile ones, this shows that the fragile group is more homogenous than the non-fragile group - a handful of states that are not coded as fragile have about $40 \%$ of the population without proper nourishment. The difference between the median non-fragile state and the median fragile state is considerably larger than the 
Figure 6: Trends in percentage of population that is undernourished, by conflict type and fragility
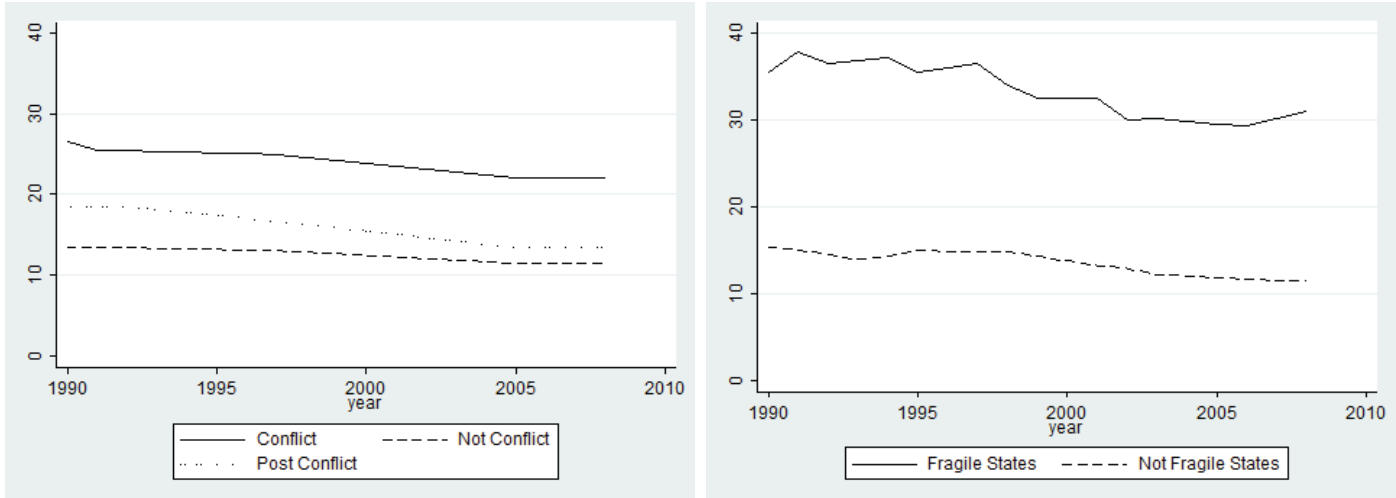

difference between the means shown in Figure 6. This is also seen to a lesser degree in the sub-figure comparing conflict, post-conflict and non-conflict countries.

Figure 7: The Percentage of Population Suffering from Undernourishment, By Conflict Status and State Fragility in 2005
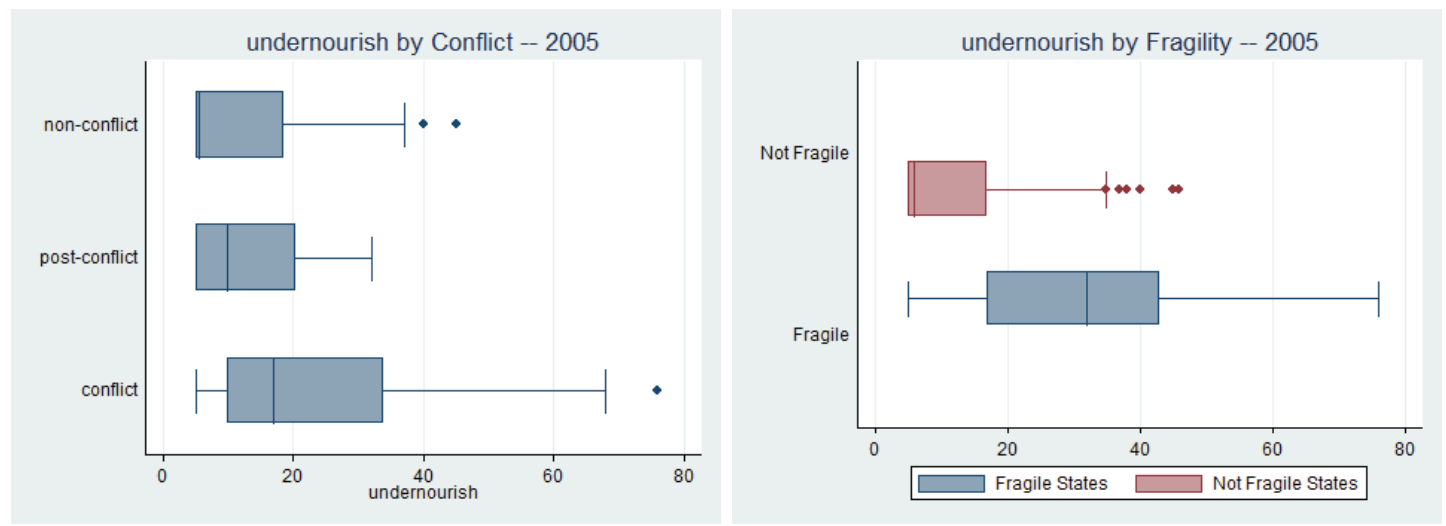

\subsubsection{Literature on Effects of Conflict on Poverty and Hunger}

Systematic studies of the effect of conflict on poverty and hunger are scarce, mostly consisting of NGO reports. Several studies confirm the popular perception that conflicts exacerbate poverty and hunger. Messer and Cohen $(2004,3)$ argue that "conflict causes food insecurity" and that civil conflicts in Africa from the mid-1960s until 2000 cost the region more than " $\$ 120$ billion worth of agricultural production". Country studies carried out in post-conflict countries also find a marked increase in poverty and hunger during war. For Angola, Sapir and Gomez $(2006,13)$ find that 
malnutrition rates were severely affected by conflict, but that "one year after the cease-fire, Angola had been able to leave behind the high rates of crude mortality and malnutrition that field surveys had recorded during conflict". For Mozambique, Brück $(2006,33)$ finds a more lasting effect of conflict. In 1997, five years after the civil war ended, he reported that in the northern part of the country "39 percent of all children under 3 years of age [were] moderately or severely underweight". Mozambique had a prevalence of undernourishment among the population of $52 \%$ in 1997 . For comparison, in Burkina Faso, which has similar GDP per capita but has largely avoided conflict, undernourishment affected only $12 \%$ of the population. ${ }^{9}$ According to the World Bank (2007, 17), Sub-Saharan Africa (SSA) "alone remains seriously off-track to achieve the poverty reduction MDG". SSA is also the region with the most civil conflict in the world.

We are not aware of any cross-national studies of conflict's effect on undernourishment beyond those reported here, nor of any systematic cross-national studies of the relationship between conflict and the poverty-headcount variables referred to in Table 8. Poverty and undernourishment, however, are to a large extent determined by economic development broadly defined and captured by the GDP (gross domestic product) measure (Collier and Dollar 2002). Several studies show that civil conflicts wreak havoc on the economies of the countries they take place in. According to Collier (1999) this happens through five processes: destruction of resources, disruption of social order, diversion of public expenditure, dissaving, and the shifting of assets out of the country. In Breaking the Conflict Trap, Collier et al. (2003) consequently describe civil war as development in reverse: "After a typical civil war of seven years duration, incomes would be about 15 percent lower than had the war not happened". There is substantial literature on the effect of conflict on economic factors, both directly on issues such as GDP growth, but also on the composition of a country's economy and on the effect on spending (for example, military expenditure). ${ }^{10}$ Here, we focus on recent articles that deal directly with the impact of civil conflict on the economy. ${ }^{11}$

Collier (1999) argues that civil wars are "liable to be more damaging than international wars" and finds that during "civil war the annual [GDP] growth rate is reduced by $2.2 \%$ ". These results

\footnotetext{
${ }^{9}$ Data from the World Development Indicators

${ }^{10}$ See Collier et al. (2003), Koubi (2005), and Chen, Loayza and Reynal-Querol (2008) for reviews.

${ }^{11}$ Refer to these studies for additional reviews.
} 
are very close to the results we present in Figure 5 (Table A-31). Collier finds a difference between long and short wars. While short wars "cause continued post-war [GDP] decline, [...] sufficiently long wars give rise to a phase of rapid growth" (Collier 1999, p. 175-176) - a "Phoenix effect" (Organski and Kugler 1980). Collier attributes the continued decline in GDP after short wars to post-war environments being less capital-friendly than pre-war capital environments. ${ }^{12}$

Koubi (2005) studies the effect of both inter- and intranational wars on average growth in per capita real output. She finds that a war's severity, measured in number of battle deaths, has a significant negative impact on growth. When she repeats the analysis for only interstate wars, the statistical significance disappears, indicating that the "association between war and economic growth is due to civil wars" (Koubi 2005, 76-77).

Koubi $(2005,78)$ also finds, in accordance with Collier (1999), that "the more severe or longer the war, the higher the subsequent, medium-term economic growth". Similarly, Chen, Loayza and Reynal-Querol (2008, p. 71) find that the "average level of per capita GDP is significantly lower after the war than before it", and they argue that this is "undoubtedly a direct reflection of the cost of war". They, too, find that after "the destruction from war, recovery is achieved through above-average growth" but this growth follows the pattern of "an inverted U, with the strongest results achieved in the fourth or fifth year after the onset of peace". (Chen, Loayza and ReynalQuerol 2008, p. 72, 79). Likewise, Blomberg, Hess and Thacker (2000) find a strong negative effect of both external and internal conflict on growth.

In addition to the impact on the domestic economy, the effects of civil wars tend to spill over into neighboring countries (Buhaug and Gleditsch 2008; Gleditsch and Ward 2000; Salehyan and Gleditsch 2006). This spill-over takes the form of increased risk of civil war for countries with neighbors in a state a civil war, but the influence can also be substantial for the neighbors' economic growth. Murdoch and Sandler (2002, p. 96) argue that a neighboring civil war may affect a country's GDP through collateral damage where battles close to the border may destroy infrastructure and capital, and by increasing "perceived risk to would-be investors and divert[ing] foreign direct investment away from neighbors at peace". Investigating this argument, they find

\footnotetext{
${ }^{12}$ See Davies (2008) for a detailed study of post-conflict capital flight.
} 
that a civil war creates "significant negative influence on short-run growth within the country and its neighbors" (Murdoch and Sandler 2002, p. 106-07). Murdoch and Sandler (2004) extend the time frame and approach of their earlier paper. They argue that the spill-over effects may go beyond a country's immediate neighbors, "owing to regional economic integration and regional multiplier effects". In contrast to the relatively modest effects they found for immediate neighbors in the earlier paper, they find that, for neighbors within a radius of 800 kilometers "a civil war at home is associated with a decline in economic growth of 0.1648 , while an additional civil war in a neighbor is associated with a decline of approximately 0.05 or about $30 \%$ of the home-country effect" (Murdoch and Sandler 2004, 145). This implies that "a country in a region with three or more civil wars may be equally impacted as a country experiencing a civil war" (Murdoch and Sandler 2004, 150).

\subsubsection{Empirical Analysis}

The gap table (Table 1) and Figures 6 and 7 show that conflict countries and fragile states are, on average, more undernourished and poorer, and have shorter life expectancy and lower GDP per capita than countries that are neither in conflict nor fragile. To what extent is this situation caused by the conflicts and fragility themselves, rather than by factors that explain conflict, fragility, and poor development outcomes? To answer this, we look at the cross-sectional and fixed-effects analyses (see sections 2.4.1 and 2.4.2). The regression tables are reported in Appendix A.3.1.

Undernourishment The cross-sectional analysis (Table A-3) shows how conflict has affected the reduction in undernourishment from 1990 to 2004. Undernourishment is measured as a percentage of the total population. ${ }^{13}$ The combination of the exposure and '(firstnm undernourish)' variables indicates that the average improvement has been about $10 \%$ over the period for a country with an initial proportion undernourished at about $30 \%$. This analysis shows that countries that have had a large number of battle deaths in internal conflicts have reduced undernourishment to a much smaller degree. The conflict variables are statistically significant and strong both in log-transformed

\footnotetext{
${ }^{13}$ Variable name in WDI: sn_itk_defc_zs. Improvement in this variable means a reduction in undernourishment, so coefficients for variables that hamper improvement will have a positive sign in Table A-3.
} 
and non-transformed versions. A country that has gone through a war with 10,000 battle deaths has reduced undernourishment by 3.5 percentage points less than an otherwise similar non-conflict country, according to these estimates. This means that, in a country with 10 million inhabitants, the war has prevented 350,000 people from moving out of the undernourished category. ${ }^{14}$ The estimates with the non-transformed battle-deaths variable indicate an even stronger effect, but this may be driven by a few extremely lethal and detrimental cases. The left-most column indicates that undernourishment rates that are increased proportionally to the number of years with conflict reduce the improvement, but the estimates shows lots of variance around the general trend. It is the severity of the conflict that matters, not the duration.

Column 4 shows that fragile states reduce undernourishment at a much slower pace than nonfragile states. The '(sum) fsida' variable is the count of years coded as fragile over the 19902004 period. Each year of fragility is associated with an increase in undernourishment in 0.5 percentage points relative to the baseline. The relative increase allows accounting for the general decrease in global undernourishment levels shown in Figure 6 - a fragile state is estimated to reduce undernourishment by 2 percentage points over a ten-year period when a non-fragile country with similar initial conditions decreases it by 7 percentage points.

The right-most column estimates the relationship between improvement in nourishment and the average value for the CPIA index over the period. This estimate is not significant - controlling for initial undernourishment rates, the CPIA index explains little change in this variable. This indicates that the PKO component of the fragility index is more important than the CPIA component, and further underscores the detrimental effect of conflict.

Table A-7 shows the results from estimating a set of fixed-effects models for this dependent variable. To account for global changes in the average levels for the indicators, we include dummy variables for each five-year period. In Model 1, we estimate the effect of the conflict variable. Conflicts clearly lead to undernourishment in the following five-year period. The estimate for the conflict variable is 0.78 , implying that a single year of minor conflict increases the proportion of

\footnotetext{
${ }^{14}$ Obviously, the dichotomous classification between undernourished and not undernourished is crude. Moving out of undernourishment does not mean an extreme improvement in a population's diet. In countries where a large proportion of the population has a marginal income, it may not take much to fall into the undernourished category.
} 
the population that is undernourished by $0.8 \%$. Five years of major conflict is estimated to lead to an $8 \%$ increase in this proportion.

We have tested whether the effect of conflict is contingent on the size of the country - in a large country, a conflict may be extremely detrimental to the region experiencing warfare, but have little impact on the country as an entity. We do not find signs of such an interactive term, however. For this outcome, the effect of conflict seems to be country-wide. The fixed-effects analysis indicates that the cross-sectional analysis underestimates the effect of conflict in this case. It implies that for a country of median size of about 10 million inhabitants, a single year of conflict (with up to 1,000 battle deaths) moves a total of 80,000 people into the undernourishment category. Five years of major conflict affects about 800,000 persons.

In Models 2 and 3, the conflict measure is the count of battle-related deaths due to fighting in the five years preceding the observation period. Also, this indicator indicates a strong, detrimental effect of conflict. The estimate of 0.416 implies that a conflict of median severity $(2,500$ deaths over 5 years) increases the undernourished proportion of the population by about $3.3 \%$ percentage points. ${ }^{15}$ This corresponds to about 300,000 persons in the median country. Again, this estimate is stronger than the corresponding estimate in the cross-sectional analysis.

Figure 8 shows that the fixed-effects model estimates are clearly defined. The line shows how the undernourishment rate changes over each five-year period as conflict intensity increases. ${ }^{16}$ The vertical lines represent the $95 \%$ confidence interval around this line.

In Model 4, we estimate the effect of state fragility on undernourishment. Fragile states also have higher proportions of undernourished populations. Controlling for unobserved country-level factors and time trends, fragile states on average have $2.4 \%$ higher proportion of undernourishment than non-fragile states.

Figure 9 illustrates the estimated effect of conflict on undernourishment for a hypothetical country, with a population of about 15 million in 1970, increasing to 35 million in $2005{ }^{17}$ The initial undernourishment proportion for this country was about $20 \%$ in 1970 . The dotted line in

\footnotetext{
${ }^{15}$ The logarithm of 2,500 is 7.82 , which multiplied by the parameter estimates 0.494 is $3.3 \%$.

${ }^{16}$ The figure is produced using Clarify (King, Tomz and Wittenberg 2000).

${ }^{17}$ This is close to the size of Tanzania.
} 
Figure 8: Estimated average rate of undernourishment, by $\ln$ (battle deaths)

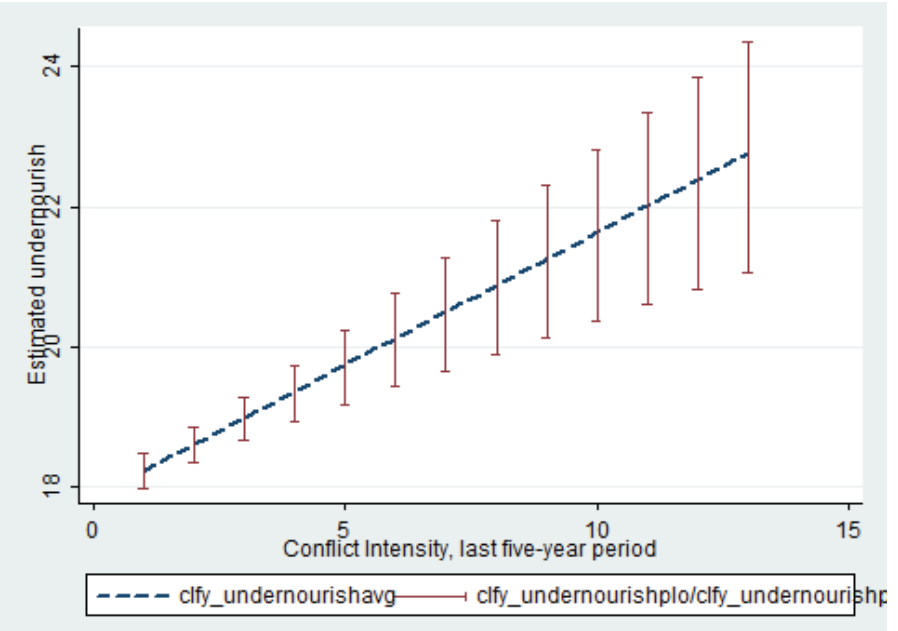

the figure represents the baseline scenario without any conflicts. The estimates of Model 1 in Table A-7 imply that the poverty rate for the hypothetical country is constant from 1970 to 1995 , and thereafter slowly decreases. ${ }^{18}$

Figure 9: Simulated effect of conflict on undernourishment.

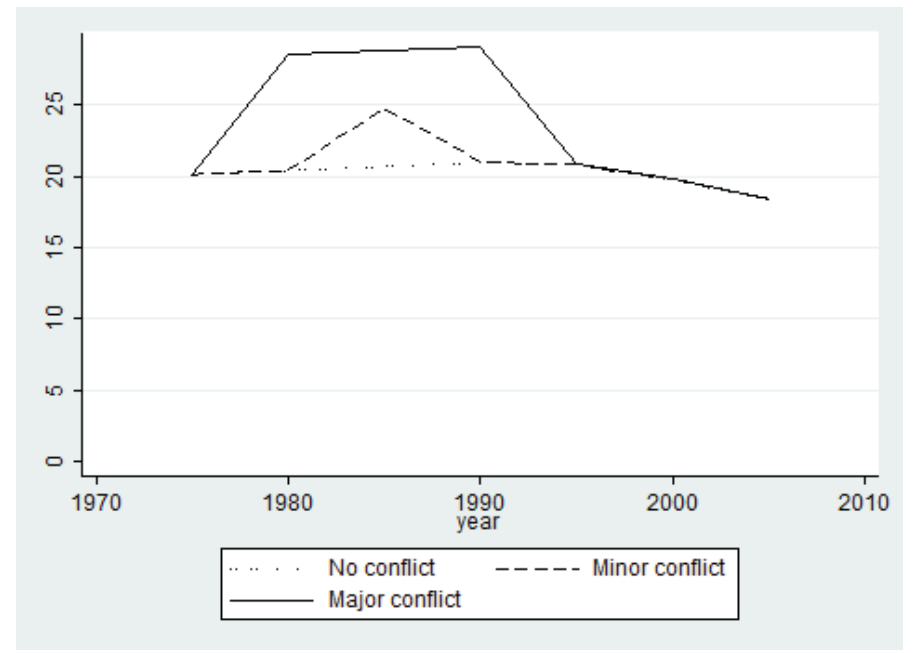

The dashed line shows estimated poverty rates if this country had five years of minor conflict starting in 1980: The prevalence of undernourishment then increases to about $25 \%$ during those

\footnotetext{
${ }^{18}$ The specification of the model underlying Figure 9 does not allow for only a partial recovery as evident for GDP per capita in Figure 5. For most of the indicators we use, we have data only for every five-year period. This precludes estimating the same type of model as the one shown in Table A-31.
} 
five years. The solid line shows estimated poverty rates if the country had fifteen years of major conflict, starting in 1975: Undernourishment then increases to $28 \%$ for the entire 15 -year period.

Poverty We now turn to the effect of conflict on poverty - the percentage of a country's population that live on less than USD1.25 per day. ${ }^{19}$ Figure 10 shows the distribution for the poverty headcount indicator for the year 2000. Just as shown in the gap table, non-conflict and non-fragile states have much less poverty than conflict and fragile states.

Figure 10: The Percentage of Population Suffering from Poverty, By Conflict Status and State Fragility in 2005

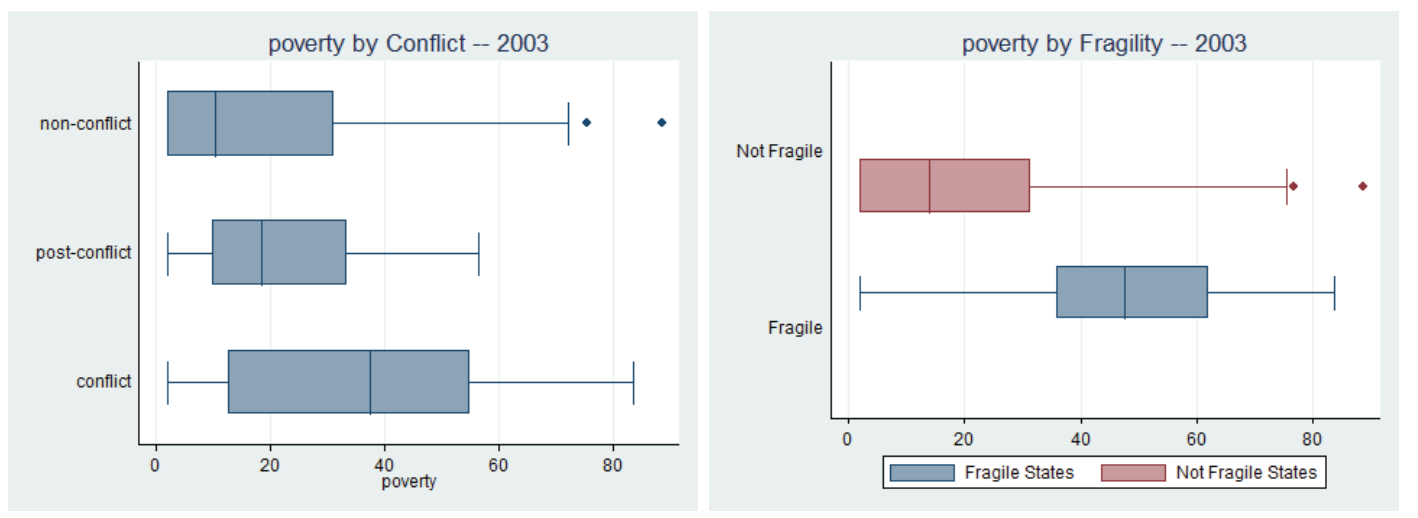

Results from the cross-sectional analysis are reported in Table A-4. Improvement is measured from 1991 to 2003. Average improvements for this indicator are very similar to those for undernourishment. Here, too, the count of conflict-years variable is positive but not statistically significant. The estimate for log battle deaths is significant, though, indicating that a typical country with a conflict causing 10,000 battle deaths reduces poverty rates $5 \%$ less over the 12 years than a comparable country without conflict.

Fragile states also reduce poverty at a slower pace than non-fragile states - each year of fragility is associated with a relative increase in poverty of about 1.3 percentage points. This is partly due to poor governance - improvement is estimated to be about 0.18 percentage points larger for each additional point-year on the CPIA scale. In other words, over the 13-year period from 1991 to 2003, a country would have reduced poverty by 2.4 percentage points more if it had a CPIA score

\footnotetext{
${ }^{19}$ Variable name in WDI: si_pov_dday.
} 
that was one unit higher.

The results for the fixed-effects analysis of the relationship between conflict, fragility, and poverty are presented in Table A-8. In contrast to the cross-sectional analysis, we find little trace of a direct effect of conflict on poverty. Estimates are largely in the expected direction, but not statistically significant. This is partly due to data sparseness - we have three consecutive observations for only just above 50 countries and never more than 89 countries for a given year. Data also tend to be most sparse in conflict countries - for example, we lack data for Afghanistan, DRC, Algeria and Sudan for the year 2000.

Life expectancy Figures 11 and 12 show the distribution and trends for life expectancy. The box plots show that fragile and conflict countries have lower average life expectancy than other countries. The trend figures show the same differences in average life expectancies, but indicate that conflict countries gradually catch up with non-conflict countries. This is likely because the potential for improvement is much higher in countries with low initial life expectancies.

Figure 11: Distribution of life expectancy in 2005 by conflict and state fragility status
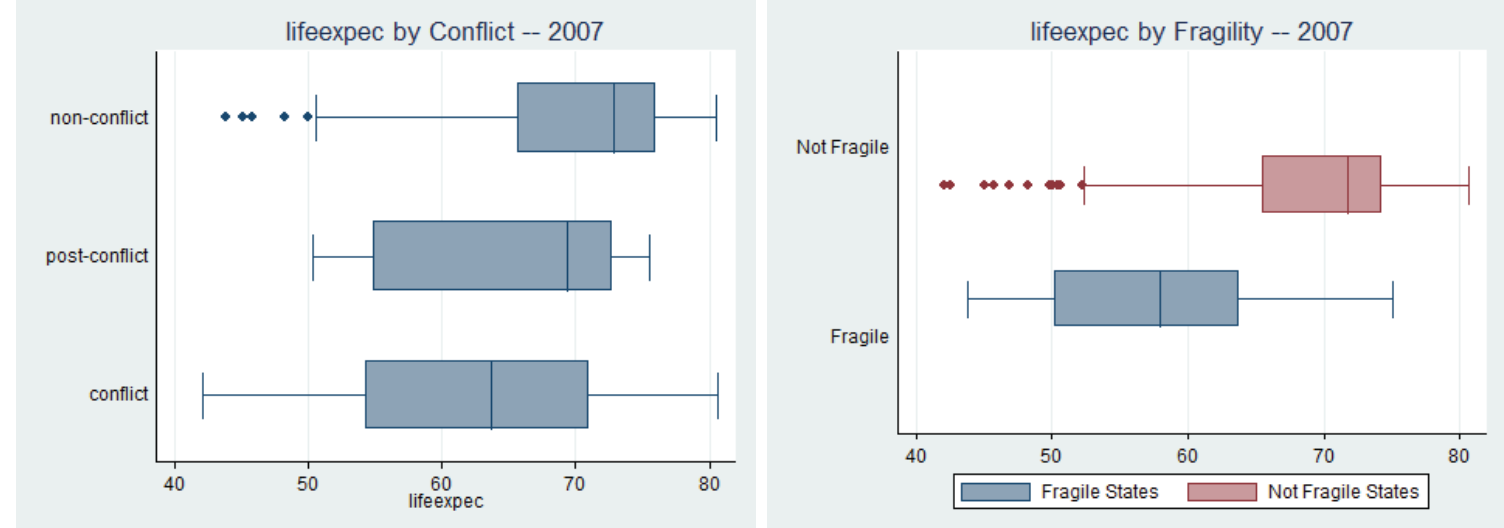

As for undernourishment, Figure 11 shows that a few non-conflict and non-fragile states have low life expectancies in 2005. Conflict and fragile states, on the other hand, have consistently lower values for this indicator.

Life expectancy is a useful measure since it is a function of a wide range of health and mortality factors, many of which are likely to be affected by conflict. The disadvantage of this variable is 
Figure 12: Mean life expectancy over time by conflict and state fragility status
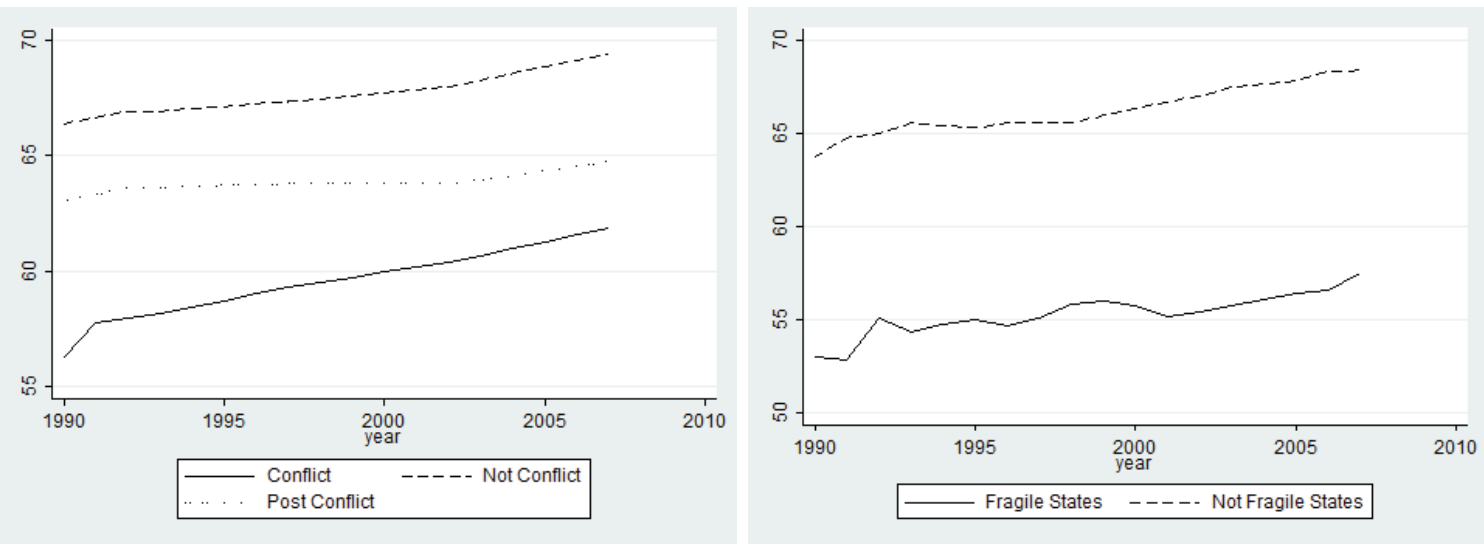

that it is estimated on the basis of demographic data and responds slowly, even to serious shocks to the health of a population. This may make it difficult to locate a causal effect from fragility and conflict to changes in the variable.

Table A-5 shows the results from estimating the cross-sectional models with life expectancy as the MDG1 indicator. For this indicator, we use data from 1967 to 2007 . We account for the fact that countries with low initial life expectancy improve more quickly by adding the initial value as a control variable. Given this, it is clear that countries with conflict improve much more slowly than non-conflict countries - ten years of war or a total of 10,000 battle deaths is associated with a reduction in life expectancy of more than two years relative to the non-conflict counterfactual. For a median-sized country with 10 million inhabitants, the estimates indicate a loss of about 20 million life years. Only about 500,000 of these life years can be attributed to direct battle-related deaths. $^{20}$

Fragile states also have less improvement in life expectancy than non-fragile states - each year of fragility is associated with a reduction in life expectancy of about 0.2 years. The CPIA indicator is also significant and has the expected sign. Over the 30 years with CPIA data, a country with CPIA scores systematically one unit higher than the average developing country, which is estimated to increase life expectancy by 0.6 years. Table A-5 shows that conflict and fragility variables also appear as reducing life expectancy in the conservative fixed-effects models. The estimates are

\footnotetext{
${ }^{20}$ If the average age of soldiers killed is 20 years and we expect them to live to age $70,10,000$ deaths amounts to 500,000 life years. This estimate is probably too high.
} 
negative and significant in all the models we report. The magnitude of these estimates is quite similar to those in the cross-sectional analysis.

Growth Undernourishment, poverty headcount, and life expectancy are closely related to the economic production of a country - low-income countries are poor, and studies such as Collier and Dollar (2002) show that economic growth on average also reduces poverty. It is therefore useful to study how conflict and fragility affect economic growth.

Figure 13: Mean GDP per capita over time by conflict and state fragility status
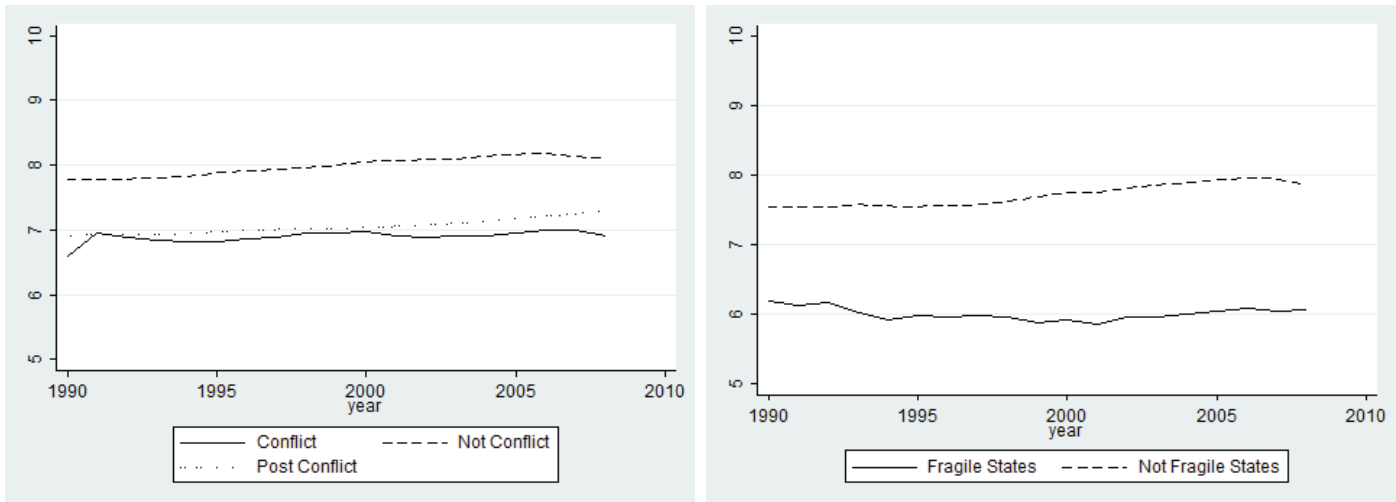

Figure 13 shows the trends in average GDP per capita for countries separately for the three conflict categories as well as for the two state-fragility categories. The figure shows clearly that nonconflict and non-failed countries are much richer than the conflict- and failure-affected countries. Moreover, the non-conflict and non-failed countries have seen substantial economic growth over the period, whereas the other groups have stagnated.

Figure 14 shows the distribution in GDP per capita for the year 2005 for the various categories. There are a few high-income conflict countries, but no high-income fragile states. Table A-6 gives evidence that conflict and fragility hamper growth. Measured as log battle deaths, a country with a conflict with 10,000 fatalities is estimated to lose 0.45 of log GDP per capita after the war relative to a non-conflict country. In other words, if initial conditions were the same and the conflict country ended up at a GDP per capita of USD1,000 after the war, the non-conflict country is likely to have grown to about USD1,500.

Table A-10 shows the estimates from a fixed-effects model estimation of the relationship between 
Figure 14: Distribution of GDP per capita in 2000 by conflict and state fragility status
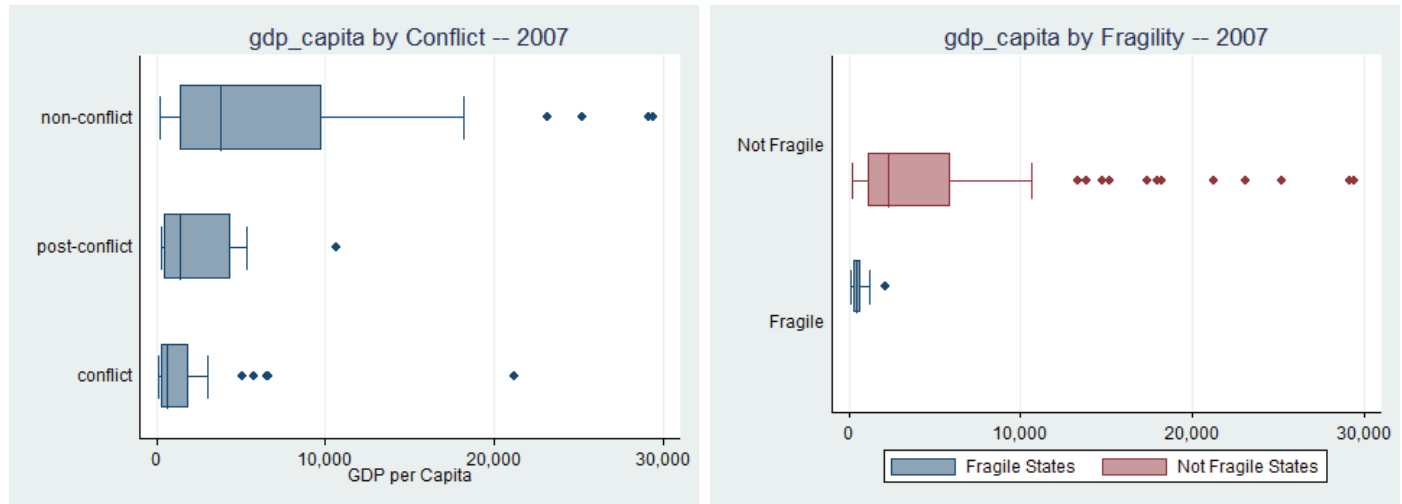

conflict and economic growth measured as the annual increase in log GDP per capita. Using a dataset with annual observations, we estimate an OLS model with panel-corrected standard errors, correcting for autocorrelation. ${ }^{21}$ Conflict clearly affects economic growth in our estimations, corroborating the studies reviewed above. One year of minor conflict is estimated to reduce annual growth by $1 \%$ to $2 \%$, major conflicts are assumed to have twice as high an effect. The analyses using battle deaths as conflict variables indicate effects of the same magnitude - minor conflicts with 25 battle-related deaths per year lead to an annual $1 \%$ growth shortfall, whereas the most lethal conflicts with more than 100,000 deaths per five-year period cause a growth reduction of about $4 \%$ per year.

\subsection{MDG 2: Universal Education}

\subsubsection{Global Trends}

As for the other indicators we analyze, global average education enrollment and attainment levels have seen a steady improvement from the 1960s to today at the global level. On average, countries have improved attainment percentages by about $2 \%$ in every five-year period. Figure 15 shows trends in secondary education levels. The Y axis shows the proportion of the population in the relevant age group that completes secondary education.

The group of conflict countries has attainment rates about $15 \%$ lower than the non-conflict

\footnotetext{
${ }^{21}$ We assume that the autocorrelation is similar for all panels. Estimated autocorrelation is relatively weak, at about $\hat{\rho}=0.35$.
} 
Figure 15: Trends in secondary education attainment rates 1990-2008, by conflict and fragility
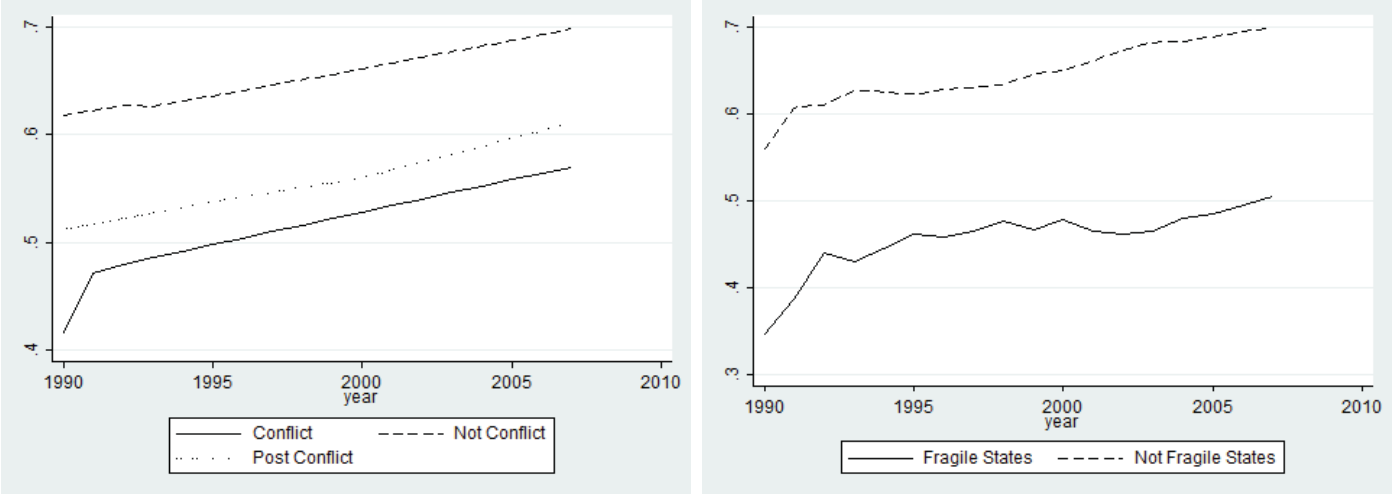

group and shows no signs of closing the gap. The group of fragile states lags behind the non-fragile states to a similar extent, and this gap seems to widen rather than to narrow. Figure 16 shows the distribution in attainment rates within the various groups we analyze.

Figure 16: Distribution of secondary education attainment rates in 2000, by conflict and fragility
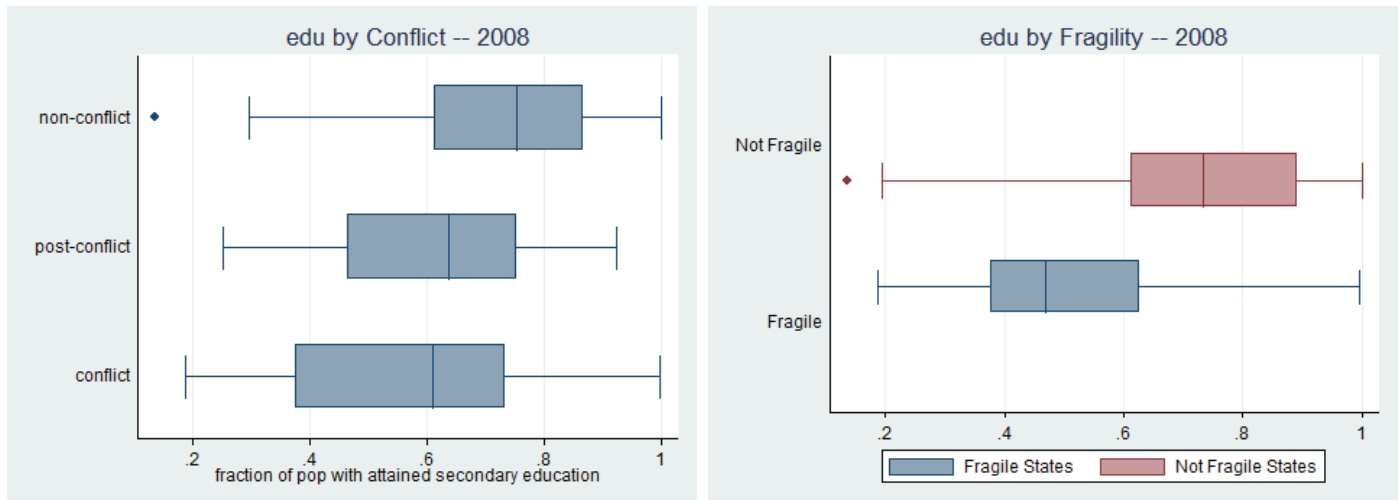

A similar pattern can be seen from figures depicting the trends and distribution in primary education attainment rates. ${ }^{22}$

\subsubsection{Literature on Effects of Conflict on Education}

The effect of conflict on education is especially interesting given education's importance for development in general. In the 1990 edition of the World Development Report (World Bank 1990), education is seen as one of four key components for combating, for example, poverty, and education

\footnotetext{
${ }^{22}$ The initial gap is wider between conflict and non-conflict countries, but may be narrowing. The initial gap between fragile and non-fragile states is also wider, but this gap increases from 1990 to 2008 .
} 
coupled with economic growth is often seen as the way out of a conflict trap (Collier et al. 2003). The effect of conflict on education has received more systematic attention from researchers than poverty and hunger. Several African country studies exist, all reporting significant negative effects of conflict. In a study on the educational cost of World War II, Ichino and Winter-Ebmer (2004) find that children of school age during that war received less education than children in neutral countries, and these individuals experienced a significant earnings gap 40 years later. World War II is unique in terms of size and severity, but researchers find similar results for civil conflicts too. On the aggregate level, Lai and Thyne (2007) find that during civil war a state "reduces its educational expenditures by $3.1 \%$ to $3.6 \%$ each year". Perhaps more significant, the authors find that this reduction in spending is not due to a "guns for butter" tradeoff but that civil wars disrupt a state's "general ability to provide social services like education to its citizenry". Lai \& Thyne find a similar effect of conflict on education enrollment. This is perhaps more disturbing because such an effect is likely to linger on long after the conflict has ended. In a report on Afghanistan, Human Rights Watch $(2007,74)$ document several direct attacks on schools, and argue that schools might become the target of attacks because they are seen as "symbols of the government or the work of foreigners". However, such an argument has not, to the best of our knowledge, been made for other conflicts.

\subsubsection{Empirical Analysis}

Table A-11 shows the results from estimating a cross-sectional model of improvements in primaryschool education attainment. Countries that have had conflict have increased school attainment more slowly than similar countries that have avoided war. Our standard example, a war with 10,000 battle deaths, is associated with a relative decrease in attainment of about 7.5 percentage points. Fragile states also improve education levels considerably more slowly than non-fragile states. Over a ten-year period, the estimates indicate that a non-fragile state improves education attainment by 8.7 percentage points more than an initially similar fragile state. Table A-16 indicates that similar patterns hold for secondary education.

Table A-13 shows the results from estimating fixed-effects regression models of the effect of 

conflict on primary education enrollment as a percentage of the relevant age group. ${ }^{23}$ The first columns present results for models with our various conflict variables. The estimates indicate that conflicts adversely affect enrollment rates, but are not statistically significant. Figure 17 shows how estimated primary school enrollment rates change with conflict in the country. Enrollment rates decrease with conflict, but the wide confidence band shows that the result is not unclear statistically.

Figure 17: Estimated average enrollment in primary education, by $\ln$ (battle deaths)

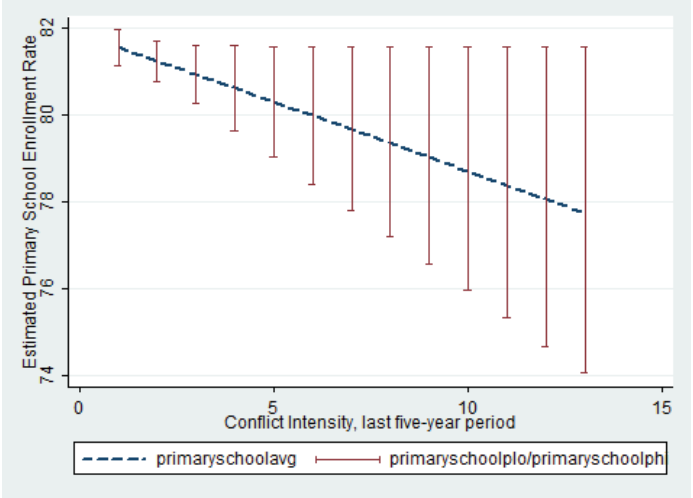

The state fragility index seems to be associated with primary-school enrollment rates, but in the opposite direction of what one would expect. The CPIA index is not significant.

Table A-14 shows the same set of models for male secondary-school attainment rates, measured as the percentage of the relevant age group. Again, there is no discernible effect of conflict on education levels in the country - none of the estimates are statistically significant.

Conflicts in the neighborhood do seem to hurt secondary education. Countries that have a neighbor that had five years of minor conflict in the preceding period experience an average reduction in education attainment of $1.3 \%$. This roughly corresponds to losing 3 to 4 years of development relative to similar countries located in peaceful neighborhoods.

\footnotetext{
${ }^{23}$ Variable name in WB dataset: se_prm_nenr. Source: WDI.
} 


\subsection{MDG 3: Gender Parity}

\subsubsection{Global Trends}

Figure 18 shows trends in the ratio of female to male primary school enrollment levels from 1990 to 2007. The group of conflict countries started as considerably less favorable to female education than non-conflict countries, but the gap in terms of percentage points difference between girls and boys is decreasing. This probably overestimates the extent to which this gap is closing, however: $100 \%$ is full gender parity, so it takes more for a group to increase this measure by one percentage point the closer it comes toward this limit. The trends for fragile versus non-fragile states show a similar gap, with no evidence that it is closing.

Figure 18: Trends in female-to-male primary education enrollment ratio 1990-2008, by conflict and fragility
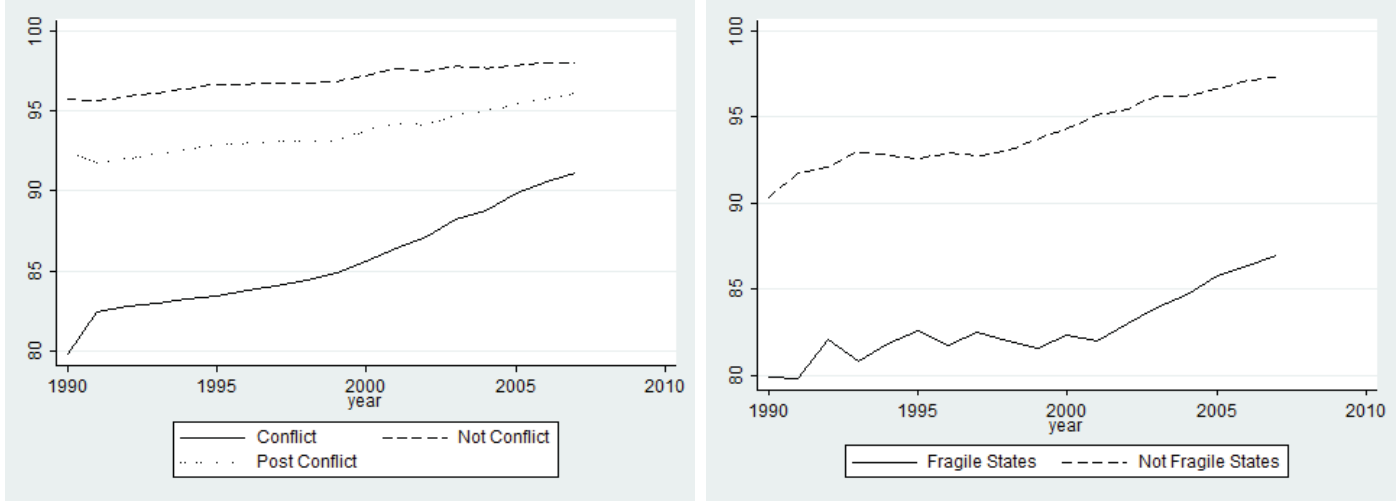

Figure 19 shows the distribution for this variable in 2000 for the various groups.

Figure 20 shows trends in the ratio of female to male life expectancy. The global average ratio in 2000 was about 1.06 (see Figure 21) - women live longer than men for physiological reasons. The conflict group has a slightly higher ratio than the non-conflict group, whereas the fragile state group has a lower ratio than the non-fragile states. This may be because fragility is a more important determinant of this measure - recall that non-conflict fragile states are coded as not in conflict in all the figures of this type. ${ }^{24}$ Moreover, it is likely that conflicts are also detrimental to male life expectancy - after all, most soldiers are male, and this is probably also the case for conflict-related

\footnotetext{
${ }^{24}$ The categorization is different from that in Table 1.
} 
Figure 19: Distribution of female-to-male primary education enrollment ratio in 2000, by conflict and fragility
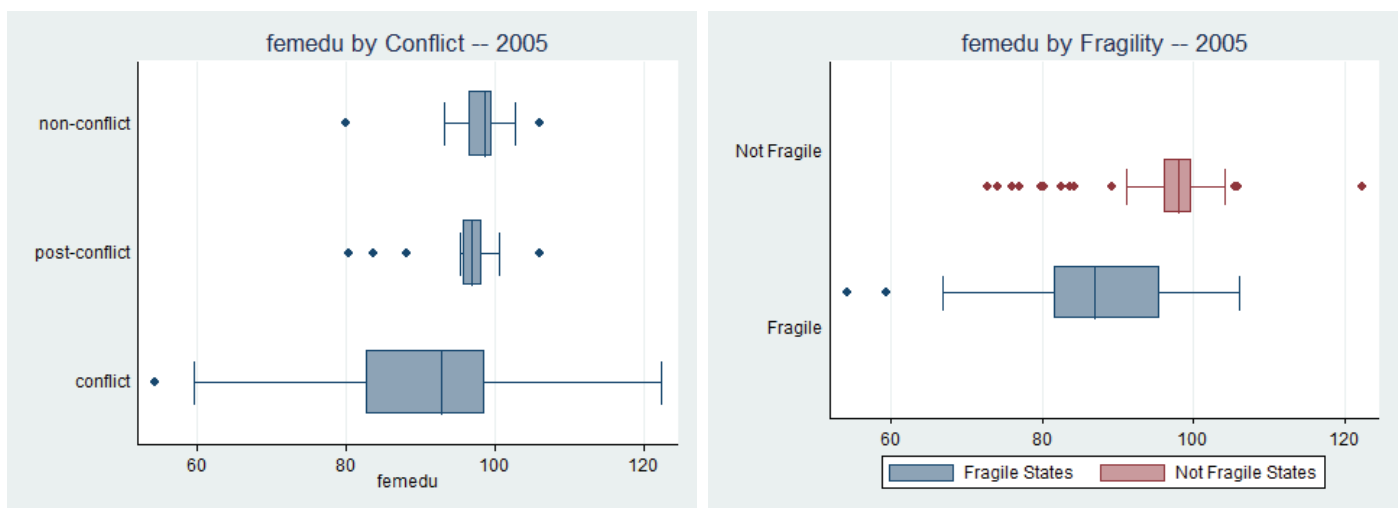

homicides.

Figure 20: Trends in female-to-male life expectancy ratio 1990-2007, by conflict and fragility
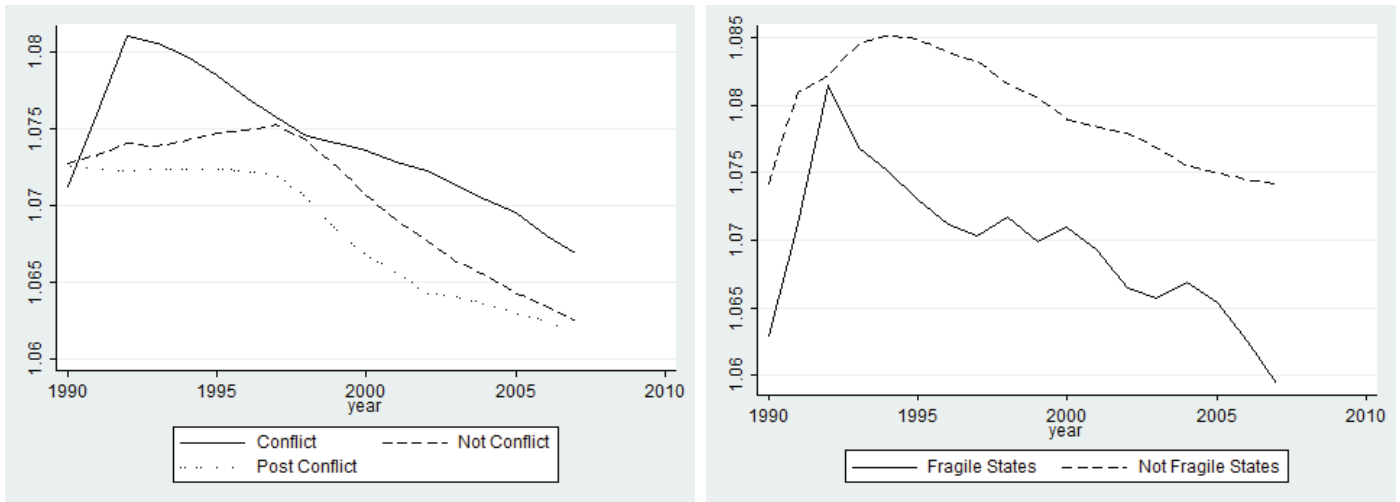

Figure 21 shows the distribution for this indicator for the year 2000.

\subsubsection{Literature on Effects of Conflict on Gender Equality}

With the adoption by the United Nations Security Council of Resolution 1325 "Women, Peace and Security" there has been a growing interest in gender and war. There is a burgeoning literature on gender and conflict, but mainly with conflict as the dependent variable. Caprioli (2000) and Caprioli and Boyer (2001) study various forms of interstate crisis and find that having more gender equality at the domestic level leads to states behaving more peacefully in international relations. Similarly, Melander $(2005 a, b)$ finds gender equality to be negatively correlated with human rights 
Figure 21: Distribution of female-to-male life expectancy ratio in 2000, by conflict and fragility

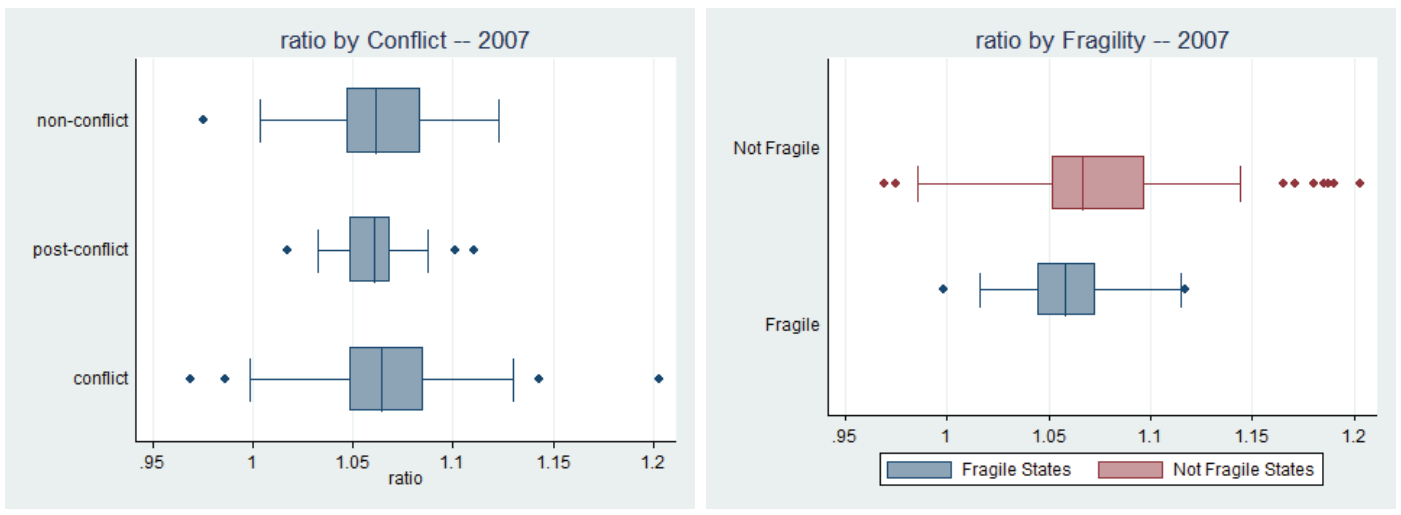

abuses as well as intrastate conflict.

Some studies find that conflicts harm women more than men, although most soldiers are men. The International Committee of the Red Cross (2001, p. 28) argues that "women are particularly susceptible to marginalization, poverty and the suffering engendered by armed conflict, especially when they are already victims of discrimination in peacetime". The United Nations Development Fund for Women (Rehn and Sirleaf 2002, p. 6) states, "The magnitude of violence suffered by women before, during and after conflict is overwhelming". The most systematic study of the impact of armed conflict on gender differences in conflict effects has been carried out by Neumayer and Plumper (2006). They find a significant and largely robust negative effect of conflict on female life expectancy, and conclude that "a civil war reduces [the female to male life expectancy ratio] by 0.34 percentage points" and that this shows that "the direct and indirect consequences of wars combined either kill more women than men or that the killed women are younger on average than the killed men" (Neumayer and Plumper 2006, 744, 747).

\subsubsection{Empirical Analysis}

Table A-16 presents the results from estimating a cross-sectional regression of improvement in the female-to-male primary-education ratio. The positive sign for the coefficient for the exposure variable (number of years between the first and last observations) reflects the general trend toward increased parity, and the variable labeled '(firstnm) femedu' (initial value for the education gender ratio variable) that this trend is stronger the more disadvantaged females are at the initial year of 
the cross-section. Controlling for these factors, all our conflict and fragility indicators (except the CPIA score) indicate a reduction in this improvement. The association is strong - 10 years of war means a relative decrease in parity of about $3.8 \%$, and 10 years of fragility, a relative decrease of $3.4 \%$.

Table A-17 shows the standard set of models run with the ratio of female to male primary school enrollment (measured as a percentage). ${ }^{25}$ The results of this analysis are contra-intuitive. In contrast to the clear negative relationship between conflict and gender parity seen in Figures 18 and 19 and in the cross-sectional analysis, this analysis indicates a positive relationship. This is puzzling, but may possibly be because our standard model specification is ill suited in this particular case. Gender parity is difficult to analyze, because the trend within each country shows a very predictable movement towards gender parity. Some countries move towards parity faster than other countries, and this unobserved quantity is apparently highly correlated with population size. When we add country fixed effects, the global time fixed effects are less efficient than population, which end up being strongly positive. Compare this with the AR(1) model, where the temporal fixed effects are strong but where population is not. Similarly, the post-conflict indicators are also more likely to show up late in the dataset, and might therefore pick up this trend. In the fixed-effects models, conflict appears to level out gender differences, whereas there seems to be no effect in the AR(1) model. Neither of these models appears very trustworthy. Observing that the lagged dependent variable accounts for $91 \%$ of the variance in gender parity, we use this variable and population to create a set of matched observations, and based on these matches, we find a statistically significant effect of -3.10 from the presence of any conflict in the preceding ten years on gender parity. This latter result throws further doubt on the positive effect from the fixed-effects models.

\footnotetext{
${ }^{25}$ Source: United Nations Educational, Scientific, and Cultural Organization (UNESCO) Institute for Statistics. Note: the break in the series between 1997 and 1998 because of the change from International Standard Classification of Education 76 (ISCED76) to ISCED97. Recent data are provisional.
} 


\subsection{MDG 4: Infant Mortality Rates}

\subsubsection{Global Trends}

Figure 22 shows the trends in infant mortality rates for non-conflict, post-conflict, and conflict countries as well as for fragile and non-fragile states. ${ }^{26}$ Globally, infant mortality rates have decreased considerably over the past decades. This is the case for all of groups in the figure - the group of conflict countries has in fact decreased infant mortality rates by a larger degree than the group of non-conflict countries. The gap between fragile and non-fragile states, on the other hand, has been widening over the 18 years for which we have data.

Figure 22: Trends in average infant mortality rates 1990-2008, by conflict and fragility
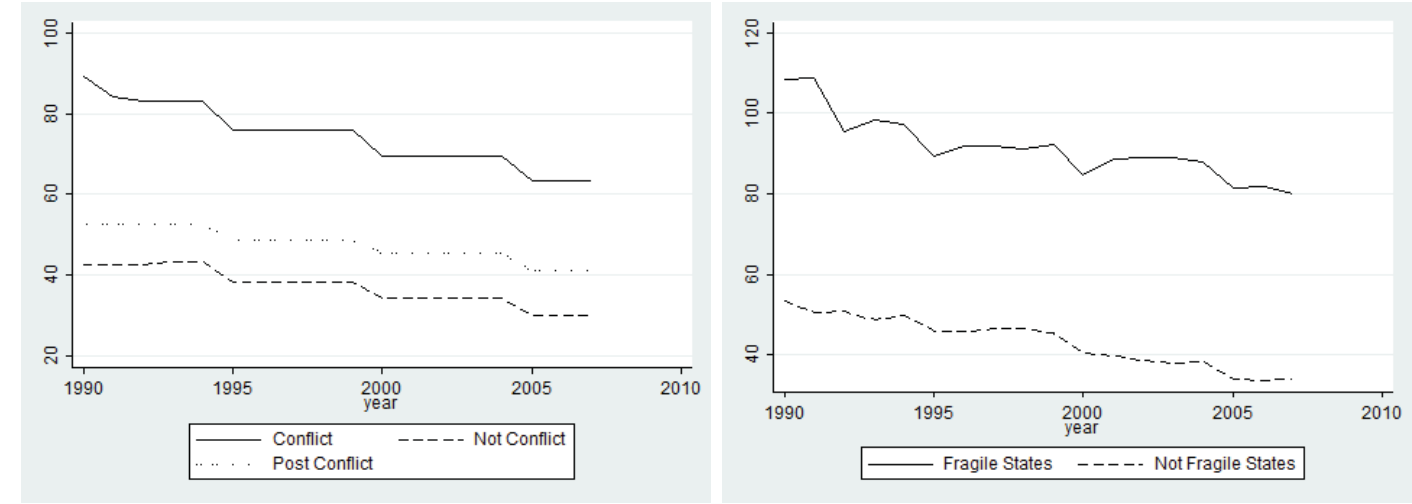

Figure 23 shows the distribution of infant mortality rates across our groups.

Figure 23: Distribution of average infant mortality rates in 2000, by conflict and fragility
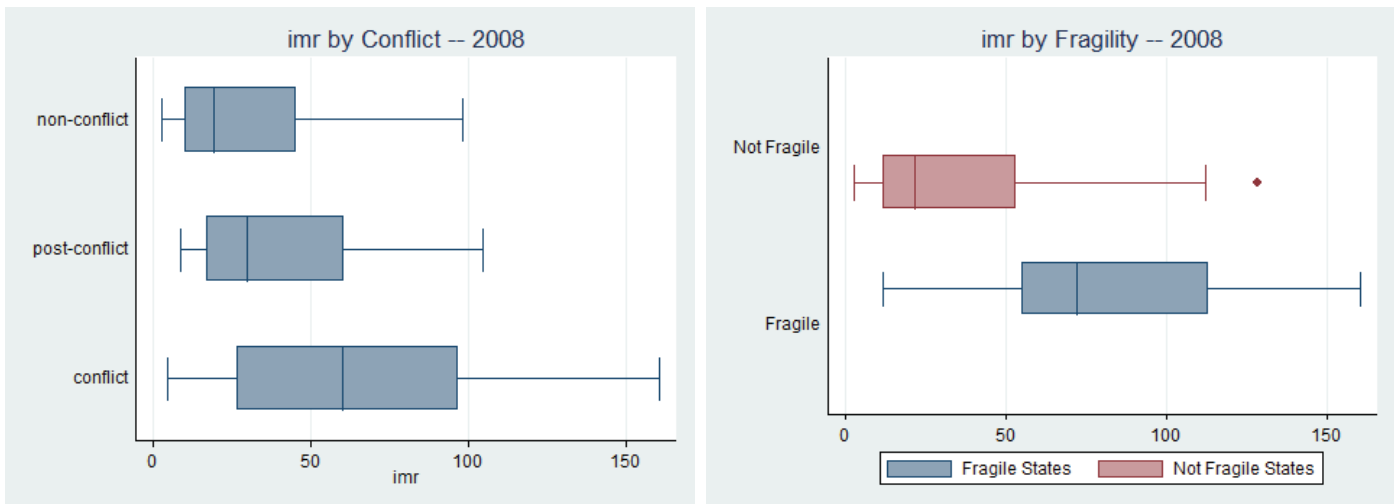

${ }^{26}$ Variable name in WDI dataset: ssp_dyn_imrt_in. 


\subsubsection{Literature on Effects of Conflict on Infant Mortality}

Infant mortality is highly correlated with other indicators of socio-economic development such as GDP per capita. Effects of conflict on infant mortality are likely to be similar to those for GDP per capita. Infant mortality rates (IMR) are often employed as a proxy for a state's general socioeconomic development as an independent variable (Abouharb and Kimball 2007) because the data coverage for infant mortality is good in every region of the world.

Davis and Kuritsky (2002); Ammons (1996); Stewart, Humphreys and Lea (1997) all find that conflict increases infant mortality. For Sub-Saharan Africa, (Davis and Kuritsky 2002, 9) find that countries that experienced conflict had average infant mortality rates $10 \%$ higher than those without conflict experience. ${ }^{27}$ In contrast to the fixed-effects analysis we present below, Davis and Kuritsky $(2002,8)$ conduct a cross-national time-series regression.

The most recent and comprehensive study on the effect of conflict on infant mortality is Iqbal (2010). Employing econometric models similar to ours, she finds that infant mortality is increased by conflict. Her finding, however, is not very robust or highly significant, which she attributes to "the possibility that during protracted conflicts, populations adjust to societal conditions and appropriately guard against infant mortality. Consequently, as the conflict perpetuates, the increase in infant mortality caused by major conflict during the first year is addressed by societies through capacity building and resource allocation" (Iqbal 2010, p. 88).

\subsubsection{Empirical Analysis}

Table A-19 presents the results from the cross-sectional regression analyses. The dependent variable is the improvement from 1969 to 2006 in log infant mortality rates. Annual improvement has on average been about -0.034 , which corresponds to $3.5 \%$ annual reduction in (non-logged) infant mortality. The estimate for the '(sum) war' variable is 0.02 - every year of war implies about $2 \%$ smaller reduction in infant mortality rates than non-war countries. Minor conflicts are not clearly associated with different trends in infant mortality rates. The estimates for the battle deaths variables indicate the same relationship: For example, the log battle deaths coefficient means that

\footnotetext{
${ }^{27}$ Davis and Kuritsky (2002) use conflict data from R. Sivard's World Military and Social Expenditures.
} 
countries that have had wars leading to 10,000 battle deaths on average have lost a infant mortality rate reduction of about $25 \%$.

State fragility also hampers infant mortality rate reduction - on average, the annual reduction is $2 \%$ lower in fragile states than in non-fragile states. Table A-20 shows similar results for under-five mortality rates.

Table A-21 shows results from estimating a set of fixed-effects models with log infant mortality rates as dependent variable and various operationalizations of conflict as main independent variables. The analysis indicates that conflicts have a clear detrimental effect on infant mortality rates. We do not find the effect to be clearly contingent on the size of the country.

The results in Model 1 indicate that one year of minor conflict increases log infant mortality rates by 0.0111 , or approximately $1.11 \%$. For a country with infant mortality rates at 75 per 1,000 live births (typical of SSA in 2005), this translates into an increase to 75.9 per 1,000. The estimates imply that a 5-year major conflict increases mortality rates to 84-a considerable change. In the average conflict country, more than 1 million children are born every year. ${ }^{28}$ Increasing infant mortality rates from 75 to 75.9 means a surplus mortality of 900 children per year; increasing to 84 , a surplus infant mortality of 9,000 per year. These estimates imply that surplus infant mortality rates exceed the number of direct battle deaths in the conflict. In Africa South of Sahara, average infant mortality rates were reduced from about 94 in 1985 to 75 in 2005 . The effect of five years of civil war, then, typically sets a country back 10 years relative to African countries that avoided conflict.

Model 3 estimates the relationship between infant mortality rates and the battle deaths measure. Indeed, figure 24 shows that infant mortality increases strongly in conflict. The relationship is statistically significant as reflected in the narrow confidence bands for the estimates. Table A-22 shows very similar results from a fixed-effects analysis of under-five mortality rates and conflict.

Model 4 estimates the relationship between fragile state status and infant mortality. The relationship is very clear and of the same magnitude as a major conflict. Fragile states have infant mortality rates roughly $10 \%$ higher than comparable countries according to these estimates.

\footnotetext{
${ }^{28}$ The 23 conflict countries listed in A-1 have an average population of 57 million in 2008, and an average population in the 0-4 years age group of about 6 million, according to United Nations (2007).
} 
Figure 24: Estimated average infant mortality rates, by $\ln$ (battle deaths)

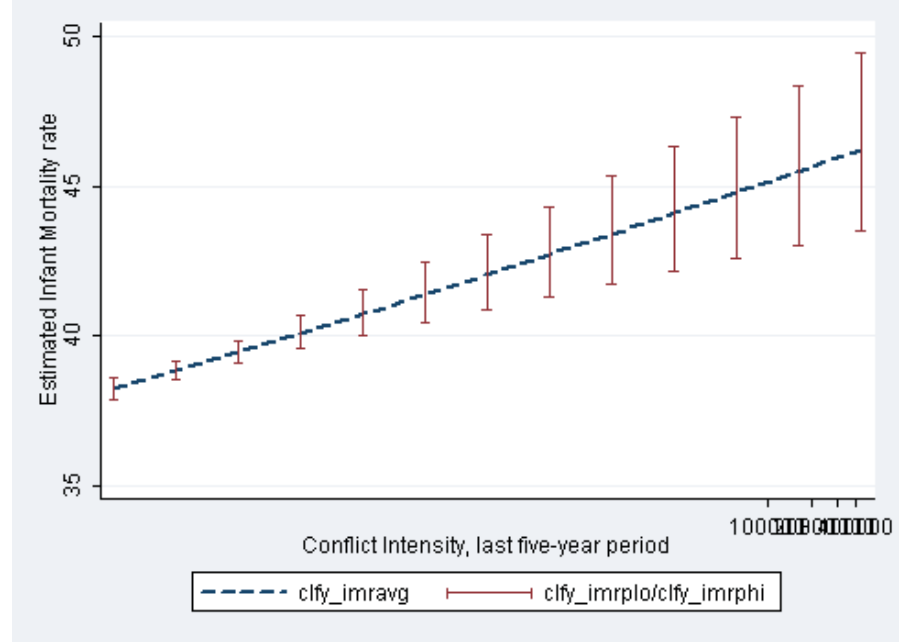

In contrast to Iqbal (2010), we find the effect of conflict on IMR to be strong and robust. The finding holds for different specifications of conflict, and the corresponding results for under-5 child mortality rates are almost similar (Table A-22).

\subsection{MDG 5: Maternal Mortality/Birth Attendance}

\subsubsection{Global Trends}

Data for maternal mortality are too sparse to allow the type of statistical study we use here, so we have to resort to a proxy. Other studies show that maternal mortality can be effectively reduced when births take place in the presence of skilled medical personnel. Figure 25 shows the trends in the percentage of births attended by skilled medical personnel for each of our groups. ${ }^{29}$ As for many other indicators analyzed in this paper, improvement in the conflict group is larger than in the non-conflict group, the post-conflict group improves more strongly than any other groups, and the fragile states group performs worst of all groups. The gap between the conflict and non-conflict group is still very large - about $60 \%$ compared to about $90 \%$ in 2008 .

Figure 26 shows the distribution of birth attendance rates across our groups.

\footnotetext{
${ }^{29}$ Variable name in WDI dataset: This variable is from the WHO not the WDI dataset!!!.
} 
Figure 25: Trends in average percentage of births attended by skilled medical personnel 1990-2008, by conflict and fragility
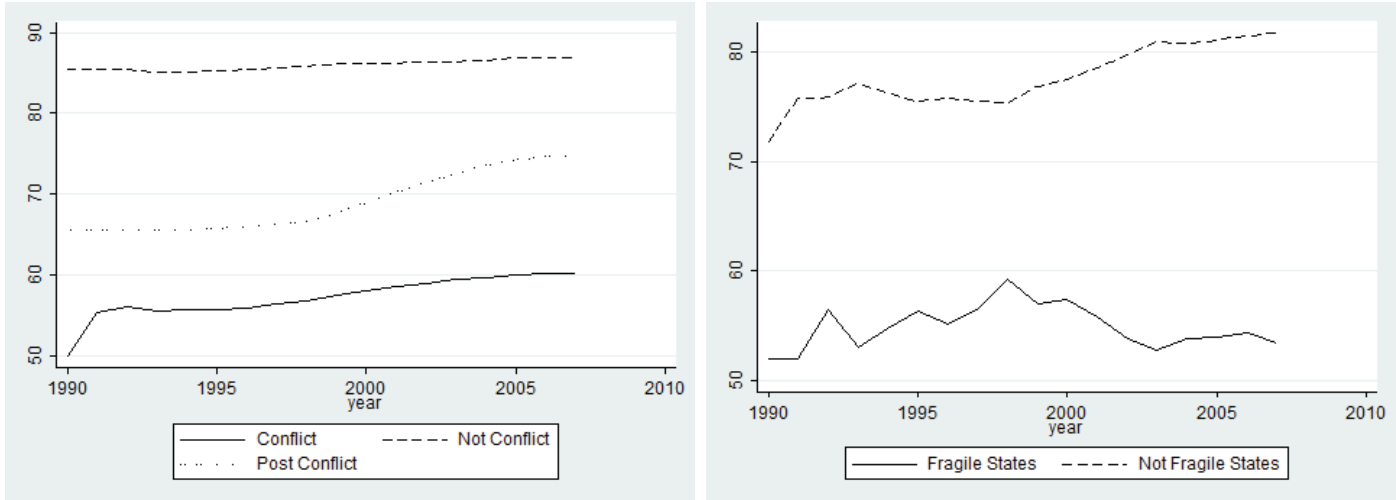

Figure 26: Distribution of average percentage of births attended by skilled medical personnel in 2000 , by conflict and fragility
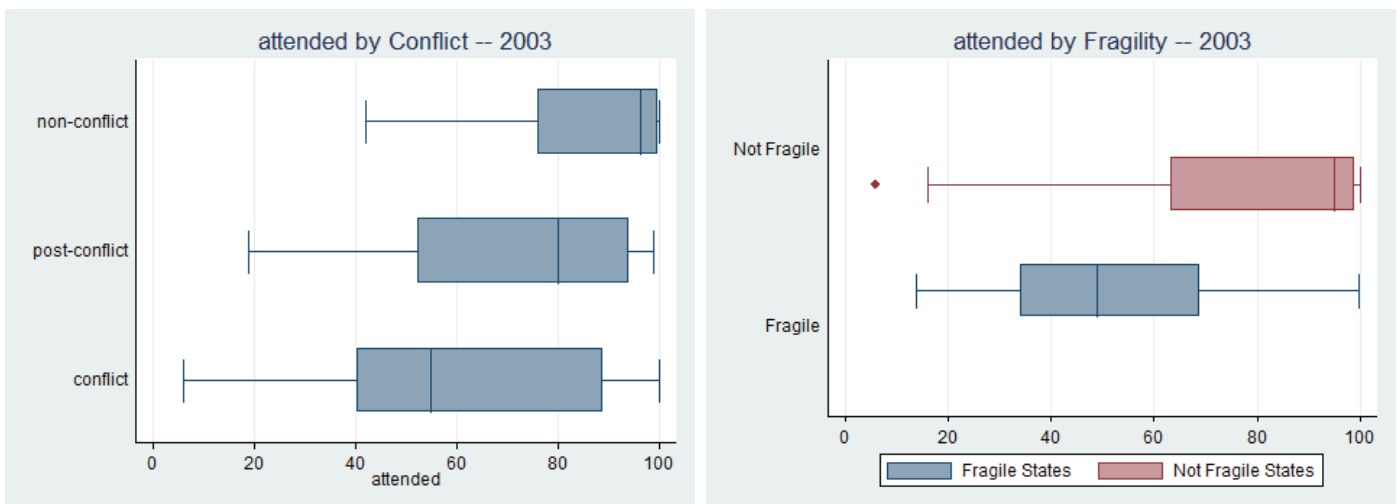

\subsubsection{Literature on Effects of Conflict on Maternal Mortality}

The literature on the effect of conflict on maternal mortality is scarce, and firm conclusions can not be drawn from it. Maternal mortality rates, however, are highly correlated with other health indicators such as infant mortality rates, and a number of studies do find that conflict adversely affects maternal mortality rates. O'Hare and Southall $(2007,564)$ find in a cross-sectional analysis of Sub-Saharan African countries that "the median adjusted maternal mortality in countries with recent conflict was 1,000/100,000 births versus 690/100,000 births in countries without recent conflict". ${ }^{30}$ Hill et al. (2007) do not study the effect of conflict in particular, but they find that $50 \%$ of all global maternal deaths occurred in Sub-Saharan Africa, a region with relatively high

\footnotetext{
${ }^{30}$ O'Hare and Southall (2007) use conflict data from the Institute of Development Studies.
} 
prevalence of conflict. As do most of the articles reviewed in this paper, the study may suffer from omitted variable bias. And other studies report divergent findings. In a case study of the city, Beira, in Mozambique, Cutts et al. (1996) do not find a strong connection between conflict and maternal mortality. Murray et al. (2002, 347) do not look explicitly at maternal mortality, but do find that war increases mortality in general. They argue, however, that "considerably more research is needed on this question before the global results on the indirect effects of conflict on mortality can be assessed".

Ormhaug and Rustad (2010) uses DHS data for 21 sub-Saharan African countries to show that fewer women received an adequate number (four or more) of antenatal visits and delivery by skilled health personnel in post-conflict countries than in non-conflict countries. The difference was discernible up to 18 years after civil war.

\subsubsection{Empirical Analysis}

Table shows results from a cross-sectional regression analysis of conflict and birth attendance. The analysis suggests that conflict hinders skilled medical personnel from attending births, but the results are statistically weak. This may be because of sparse data - we have data for a proper set of countries for only seven years, from 1997 to 2004. On the other hand, the analysis of the fragile state indicator variable shows a strong relationship despite the sparse data, as one would expect from Figure 25. On average, state fragility reduces improvement on this indicator by about $0.5 \%$ annually - given an average estimated annual improvement of $0.6 \%$, this means they hardly improve at all.

Table A-24 shows the results from a set of fixed-effects models to estimate the relationship between civil conflict and the proportion of births attended by skilled medical personnel. The data are very sparse, covering only about half of low-income countries in 2000, and considerably fewer countries in 2005 and 1995. Data before 1995 are not available. Given data sparsity, the fixed-effects models indicate no relationship between conflict and birth attendance. 


\subsection{MDG 6: Combat HIV/AIDS}

\subsubsection{Global Trends}

Figure 27 shows the trends in prevalence of HIV/AIDS 1990-2008. Prevalence is measured as the percentage of the population in the $15-49$ age group that are HIV positive. ${ }^{31}$

Figure 27: Trends in average prevalence of HIV/AIDS 1990-2008, by conflict and fragility
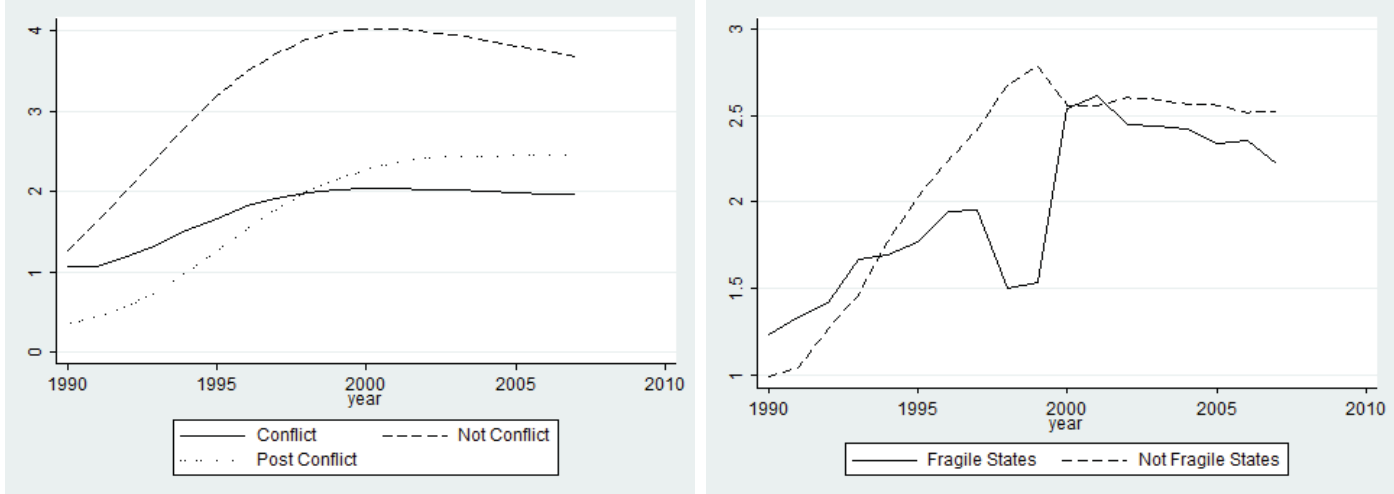

Figure 28 shows the distribution. Note the large number of extreme observations in all categories. Neither of these figures indicate a clear relationship between conflict and HIV prevalence. If anything, conflict countries have a lower prevalence of HIV/AIDS than non-conflict countries.

Figure 28: Distribution of prevalence of HIV/AIDS in 2000, by conflict and fragility
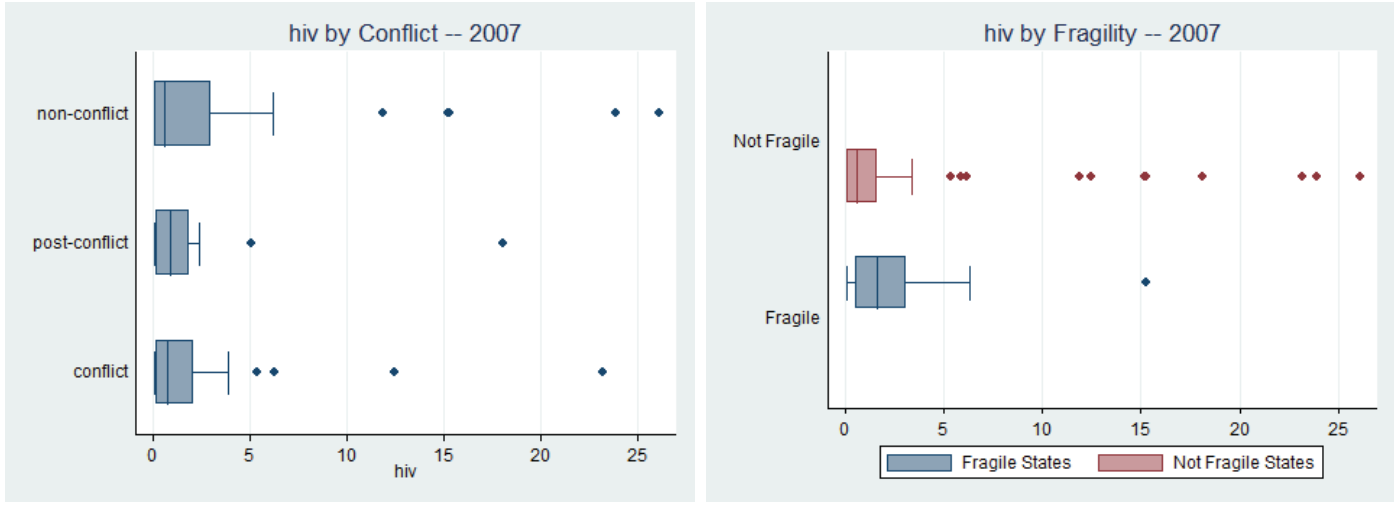

\footnotetext{
${ }^{31}$ Variable name in WDI dataset: sh_dyn_aids_zs.
} 


\subsubsection{Literature on Effects of Conflict}

Conflict and HIV/AIDS prevalence relate to each other in a complicated fashion. In contrast to the other MDG goals, some of the otherwise detrimental effects of conflict may possibly prevent the spread of this disease, which is the counter-intuitive finding of several medical studies. Using UCDP/PRIO Conflict data to create a count of the number of years a country is in conflict, Strand et al. (2007) find a marked negative effect of conflict on HIV/AIDS that they attribute to "constraints in population mobility and normal civil interactions" and possibly also to the "disruption of medical services (for example, vaccination campaigns), where contaminated needles have been reported to account for an important part of HIV transmission during peace time" (Strand et al. 2007, 470). Similarly, in a study of seven Sub-Saharan African countries, Spiegel et al. (2007) do not find any evidence for the claim that conflict increases HIV prevalence. On the other hand, violence often causes large-scale migration (Moore and Shellman 2004; Davenport, Moore and Poe 2003), and refugees and refugee camps can greatly facilitate the transmission of HIV/AIDS, as well as other infectious diseases. War can also facilitate the spread of HIV/AIDS through an increase in sexual violence often seen during conflicts. Elbe (2002) investigates how HIV/AIDS has changed the way wars are fought, and argues that the epidemic has had an impact on the "nature and conduct of armed conflict in Africa"; HIV/AIDS has influenced three components of armed conflicts in Africa: their combatants, "by diminishing the operational efficiency of many of Africa's armed forces" (163); how the conflicts are conducted, by providing armed forces with "a novel psychological and biological weapon of war" (167); and their social significance, "by significantly increasing the number of eventual war-related casualties" (171). Iqbal and Zorn (2010, 149) study violent conflict and the spread of HIV/AIDS in Africa. In contrast to the weak and often

contradictory findings in earlier studies, they conclude that there is "a clear positive relationship between both international and domestic conflict and climbing HIV/AIDS prevalence".

\subsubsection{Empirical Analysis}

Our cross-sectional analyses (Table A-25) indicate conclusions in the same direction as Figure 27 - the estimates for all our conflict and fragility measures are negative and statistically significant. 
The fixed-effects regression analysis is less clear (Table A-26). Model 1 implies that small countries with conflict have a somewhat higher HIV prevalence than small non-conflict countries. In large countries, however, the estimates indicate that conflicts reduce HIV prevalence. Conflict in neighboring countries, moreover, seems to reduce HIV prevalence.

\subsection{MDG 7: Environmental Sustainability}

\subsubsection{Global Trends}

We study two proxies for the goal of environmental sustainability. The first is the percentage of the population that has access to adequate sanitation. ${ }^{32}$ The second is the percentage of the population with access to water. ${ }^{33}$

Figure 29: Trends in the percentage of population with at least adequate access to excreta disposal facilities, 1990-2006, by conflict and fragility
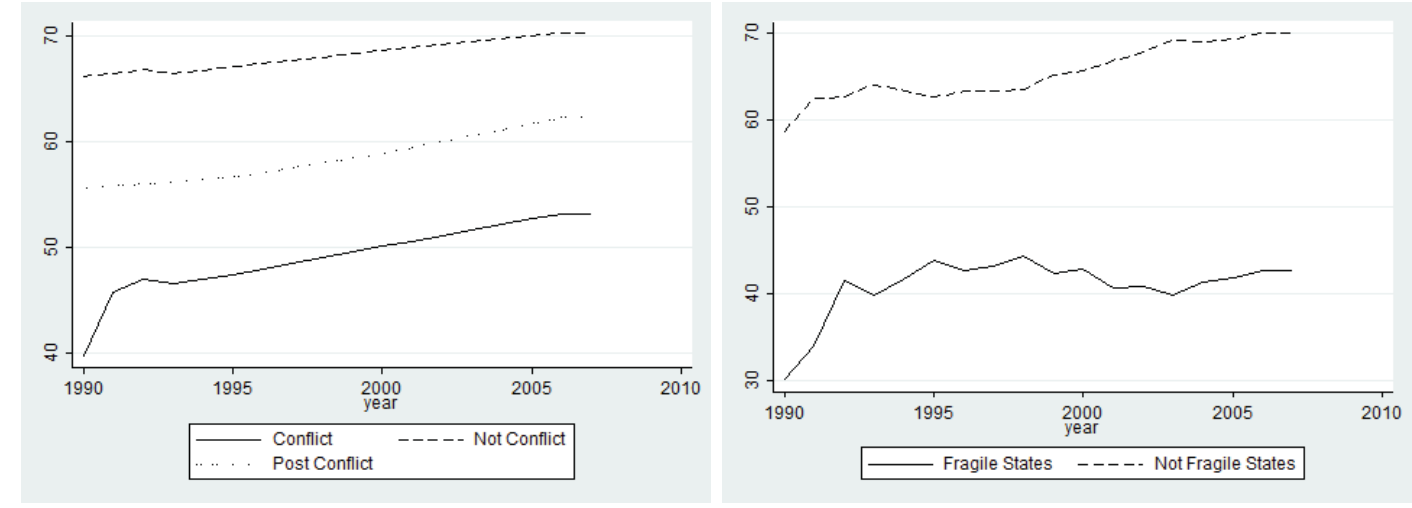

Figure 29 shows the trends in the percentage of the population with access to sanitation for each of our groups. The patterns for this outcome variable resemble most other indicators - there is a large gap at about 20 percentage points between conflict countries and fragile states on the one hand and non-conflict and non-fragile countries on the other. The gap seems to narrow slightly between conflict and non-conflict countries, but widens between fragile and non-fragile states. Figure 30 shows the distribution in the percentage of the population with access to sanitation.

\footnotetext{
${ }^{32}$ More precisely, the percentage of the population with at least adequate access to excreta disposal facilities. Improved facilities range from simple pit latrines to flush toilets. The variable is labeled sh_sta_acs in the WDI.

${ }^{33}$ The percentage of population with access to an improved water source such as household connection, public standpipe, borehole, protected well, or rainwater collection. A person must have access to at least 20 liters a day within one kilometer. The variable is labeled sh_h2o_safe_zs in the WDI.
} 
Figure 30: Distribution of the percentage of population with at least adequate access to excreta disposal facilities, in 2000, by conflict and fragility

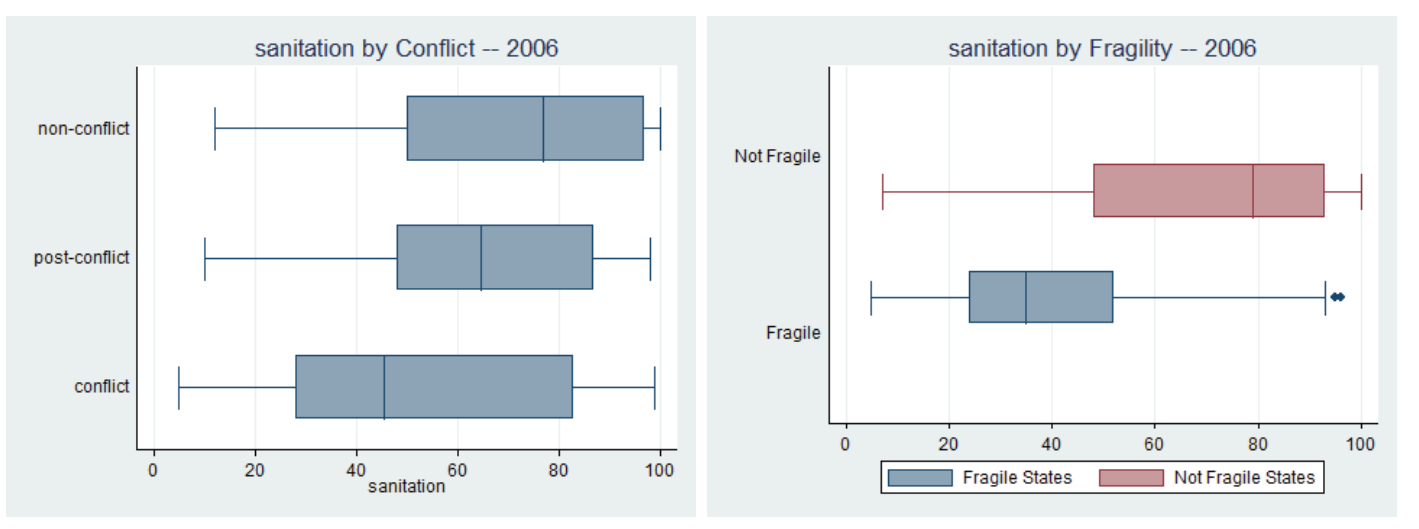

Figure 31 shows the trends in the percentage of the population with access to water. Access to water may decline during conflict because military fighting makes it inaccessible, (for example, when the conflict prevents people from traveling safely to water sources). This problem may end the day a cease-fire is called, but water may continue to be inaccessible because of land-mines and unexploded ordinance, which can take huge death tolls after the fighting has stopped. A decrease in water accessibility can also occur through the destruction of infrastructure, especially pipes and pumping stations. This source of inaccessibility may be easier to remove after conflicts, particularly when countries receive ample post-conflict official development assistance.

Access to water is also closely related to the two previous mortality measures we analyzed. As noted above diarrhea is one of the biggest killers in the wake of conflict. The spread of this disease is closely related to the availability of adequate drinking water.

Figure 32 shows the distribution of the population with access to water. A handful of nonconflict and some non-fragile states have very poor access to water in 2000 (for example, Ethiopia, Chad, Equatorial Guinea, and Madagascar). Indeed, this outcome variable may be more dependent on the physical environment than many other variables. Still, it is clear that most conflict countries and fragile states have poorer access to water than non-conflict countries. Note the improvement over time of the post-conflict states. 
Figure 31: Trends in the percentage of population with access to an improved water source, 19902006, by conflict and fragility
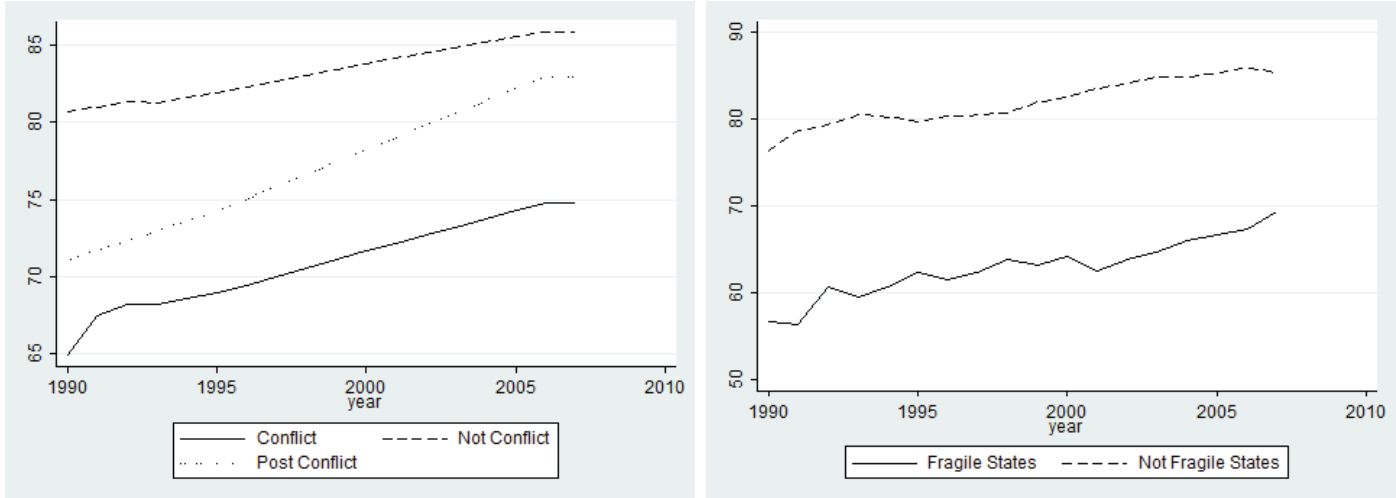

Figure 32: Distribution of the percentage of population with access to an improved water source, in 2000 , by conflict and fragility

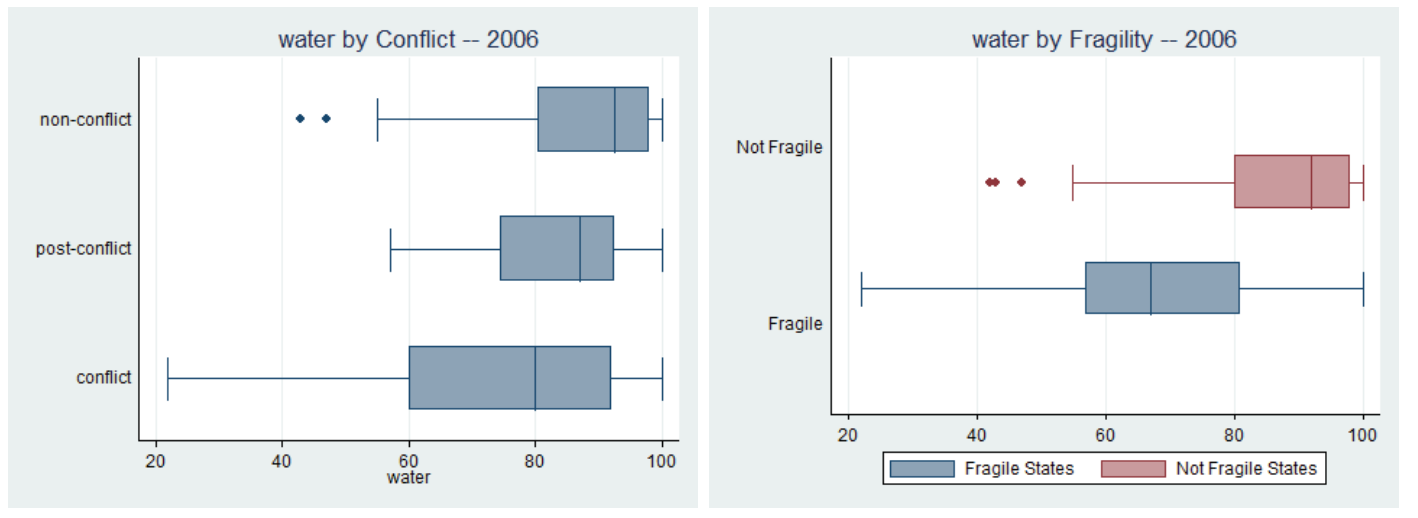

\subsubsection{Literature on Effects of Conflict}

The literature on the effect of conflict on access to adequate water and sanitation facilities is scarce. Although there has been much interest in water as an independent variable when explaining conflict (Klare 2001; Homer-Dixon 1999), almost no attention has been given to the consequences of conflict on access to water supplies. The percentage of the population that lacks access to adequate water and sanitation facilities has declined in every region of the world, but the shortfall between the MDG target and what has actually been achieved is greatest in the region with the most conflict, Sub-Saharan Africa (World Bank 2007). According to the same report, less than $20 \%$ of lessdeveloped countries are on track to reach the goal for access to water, and less than $35 \%$, the goal in access to sanitation. Similar findings are reported by the United Nations (2009, 45-46). 


\subsubsection{Empirical Analysis}

Our cross-sectional analysis on the relationship between civil conflict and our environmental variables is reported in Tables A-27 and A-28. The analysis shows that conflict clearly affects water accessibility - on average, one year of war is estimated to remove safe access from $0.5 \%$ of the population, compared to the baseline. In contrast to many other indicators, the detrimental effect of conflict is stronger than the global average annual improvement in access to water. The crosssectional analysis of conflict and access to sanitation indicates no clear relationship between the two variables.

Results from fixed-effects models are shown in Tables A-29 and A-30. These indicate no clear relationship between conflict and the environmental variables. 


\section{References}

Abadie, Alberto and Guido W. Imbens. 2006. "Large Sample Properties of Matching Estimators for Average Treatment Effects." Econometrica 74:235-267.

Abouharb, M. Rodwan and Anessa L Kimball. 2007. "A New Dataset on Infant Mortality Rates, 1816-2002." Journal of Peace Research 44(6):743-754.

Ammons, Lila. 1996. "Consequences of War on African Countries' Social and Economic Decelopment." African Studies Review 1:67-82.

Blackwell, Matthew, Stefano Iacus, Gary King and Giuseppe Porro. 2009. "cem: Coarsened exact matching in Stata." The Stata Journal 4:524-546.

Blomberg, S. Brock, Gregory D. Hess and Sidharth Thacker. 2000. Is There Evidence of a Poverty-Conflict Trap? In World Bank (DECRG) - Center of International Studies Workshop on 'The Economics of Civil Wars'. Princeton, NJ: .

Brück, Tilman. 2006. "War and Reconstruction in Northern Mozambique." Economics of Peace and Security Journal 1(1):29-36.

Buhaug, Halvard and Jan K. Rød. 2006. "Local Determinants of African Civil Wars, 1970-2001." Political Geography 25(3):315-335.

Buhaug, Halvard and Kristian Skrede Gleditsch. 2008. "Contagion or Confusion? Why Conflicts Cluster in Space." International Studies Quarterly 52:215-233.

Buhaug, Halvard and Scott Gates. 2002. "The Geography of Civil War." Journal of Peace Research $39(4): 417-433$.

Caprioli, Mary. 2000. "Gendered Conflict." Journal of Peace Research 37:51-68.

Caprioli, Mary and Mark A Boyer. 2001. "Gender, Violence, and International Crisis." Journal of Conflict Resolution 45:503 - 518 .

Chen, Siyan, Norman V. Loayza and Marta Reynal-Querol. 2008. "The Aftermath of Civil War." The World Bank Economic Review 22(1):63-85.

Collier, Paul. 1999. "On the Economic Consequences of Civil War." Oxford Economic Papers-New Series 51(1):168-183.

Collier, Paul. 2007. The Bottom Billion. Why the Poorest Countries are Failing and What Can Be Done About It. Oxford: Oxford University Press.

Collier, Paul and David Dollar. 2002. Globalization, Growth, and Poverty. Oxford: Oxford University Press.

Collier, Paul, Lani Elliot, Håvard Hegre, Anke Hoeffler, Marta Reynal-Querol and Nicholas Sambanis. 2003. Breaking the Conflict Trap. Civil War and Development Policy. Oxford: Oxford University Press.

Cutts, F. T., C. Dos Santos, A. Novoa, P. David, G. Macassa and A. C. Soares. 1996. "Child and Maternal Mortality during a Period of Conflict in Beira City, Mozambique." International Journal of Epidemiology $25: 349-356$.

Davenport, Christian, Will H Moore and Steven Poe. 2003. "Sometimes You Just Have to Leave: Domestic Threats and Forced Migration, 1964 - 1989." International Interactions 29:27 - 55.

Davies, Victor A. B. 2008. "Postwar capital flight and inflation." Journal of Peace Research 45(4):519-537. 
Davis, David R. and Joel N. Kuritsky. 2002. Violent Conflict and Its Impact on Health Indicators in SubSaharan Africa, 1980 to 1997. In Paper presented to the Annual Meeting of the International Studies Association, New Orleans, LA, March.

Degomme, Olivier and Debarati Guha-Sapir. 2010. "Patterns of Mortality rates in Darfur Conflict." The Lancet 375:294-300.

Elbe, Stefan. 2002. "HIV/AIDS and the Changing Landscape of War in Africa." International Security $27: 159-177$.

Fearon, James D. 2003. Presentation. In Workshop on Conflict Data. Oslo: .

Ghobarah, Hazem Adam, Paul K. Huth and Bruce M. Russett. 2003. "Civil Wars Kill and Maim People-Long after the Shooting Stops." American Political Science Review 97(2):189-202.

Gleditsch, Kristian S. and Michael D. Ward. 2000. "War and Peace in Space and Time: The Role of Democratization." International Studies Quarterly 44(1):1-29.

Gleditsch, Kristian Skrede. 1996. Aspects of Democratization: Economic Development, Spatial Autocorrelation, and Persistence in Time. In Norwegian National Political Science Conference. Geilo: January $8-9$.

Gleditsch, Nils Petter, Peter Wallensteen, Mikael Eriksson, Margareta Sollenberg and Håvard Strand. 2002. "Armed Conflict 1946-2001: A New Dataset." Journal of Peace Research 39(5):615-637.

Harbom, Lotta and Peter Wallensteen. 2009. "Armed Conflicts, 1946-2008." Journal of Peace Research $46(4): 577-587$.

Hegre, Håvard and Nicholas Sambanis. 2006. "Sensitivity Analysis of Empirical Results on Civil War Onset." Journal of Conflict Resolution 50(4):508-535.

Hegre, Håvard, Tanja Ellingsen, Scott Gates and Nils Petter Gleditsch. 2001. "Toward a Democratic Civil Peace? Democracy, Political Change, and Civil War, 1816-1992." American Political Science Review 95(1):33-48.

Hibbs, Douglas A. 1973. Mass Political Violence. A Cross-National Causal Analysis. New York: Wiley.

Hill, Jennifer. 2008. "Discussion of research using propensity-score matching: 'Comments on A critical appraisal of propensity-score matching in the medical literature between 1996 and 2003 by Peter Austin', Statistics in Medicine." Statistics in Medicine 27:2055-2061.

Hill, Kenneth, Kevin Thomas, Carla AbouZahr, Neff Walker, Lale Say, Mie Inoue and Emi Suzuki. 2007. "Estimates of maternal mortality worldwide between 1990 and 2005: an assessment of available data." The Lancet 370:1311 - 1319 .

Ho, Daniel, Kosuke Imai, Gary King and Elizabeth Stuart. 2007. "Matching as Nonparametric Preprocessing for Reducing Model Dependence in Parametric Causal Inference." Political Analysis 15:199-236.

Homer-Dixon, Thomas. 1999. Environment, Scarcity, and Violence. Princeton, NJ: Princeton University Press.

Human Rights Watch. 2007. "The Human Cost - The Consequences of Insurgent Attacks in Afghanistan." New York, report.

Iacus, Stefano M., Gary King and Giuseppe Porro. 2009. "cem: Software for Coarsened Exact Matching." Journal of Statistical Software 30. 
Ichino, Andrea and Rudolf Winter-Ebmer. 2004. "The Long?Run Educational Cost of World War II." Journal of Labor Economics 22:57 - 87.

International Committee of the Red Cross. 2001. "Women Facing War." Geneva: ICRC.

Iqbal, Zaryab. 2010. War and the Health of Nations. Stanford, CA: Stanford University Press.

Iqbal, Zaryab and Christopher Zorn. 2010. "Violent Conflict and the Spread of HIV/AIDS." Journal of Politics 72:149-162.

King, Gary, Michael Tomz and Jason Wittenberg. 2000. "Making the Most of Statistical Analyses: Improving Interpretation and Presentation." American Journal of Political Science 44(2):347-361.

Klare, Michael T. 2001. "The New Geography of Conflict." Foreign Affairs 80(3):49-61.

Knight, M, Norman Loayza and F. Villanueva. 1996. "The Peace Dividend: Military Spending Cuts and Economic Growth." IMF Staff Papers 43:1-37.

Koubi, Vally. 2005. "War and Economic Performance." Journal of Peace Research 42:67-82.

Lai, Brian and Clayton Thyne. 2007. "The Effect of Civil War on Education." Journal of Peace Research 44:277 - 292.

Melander, Erik. 2005a. "Gender Equality and Intrastate Armed Conflict." International Studies Quarterly 49(4):593-743.

Melander, Erik. 2005b. "Political Gender Equality and State Human Rights Abuse." Journal of Peace Research 42(2):149-166.

Messer, Ellen and Mark J Cohen. 2004. "Breaking the Links Between Conflict and Hunger in Africa.". URL: http://www.ifpri.org/sites/default/files/publications/ib26.pdf

Moore, Will H and Stephan M Shellman. 2004. "Fear of Persecution - Forces Migration, 1952 - 1995." Journal of Conflict Resolution 40(5):723 - 745 .

Murdoch, James C. and Todd Sandler. 2002. "Economic Growth, Civil Wars and Spatial Spillovers." Journal of Conflict Resolution 46:91-110.

Murdoch, James C. and Todd Sandler. 2004. "Civil Wars and Economic Growth: Spatial Dispersion." American Journal of Political Science 48(1):138-151.

Murray, Christopher, Gary King, A. D. Lopez, N. Tomijima and E.G. Krug. 2002. "Armed Conflict as a Public Health Problem." British Medical Journal 324:346-349.

Neumayer, Eric and Thomas Plumper. 2006. "The Unequal Burden of War: The Effect of Armed Conflict on the Gender Gap in Life Expectancy." International Organization 60(00):723-754.

O'Hare, Bernadette A. M. and David P. Southall. 2007. "First Do No Harm: the Impact of Recent Armed Conflict on Maternal and Child Health in Sub-Saharan Africa." Journal of the Royal Society of Medicine 100:564 - 570 .

Organski, A.F.K. and Jacek Kugler. 1980. The War Ledger. Chicago: University of Chicago Press.

Ormhaug, Christin M. and Siri Aas Rustad. 2010. "Impact of Civil Conflict on Maternal Health Care in Sub-Saharan Africa." Typescript, NorAgric. 
Raleigh, Clionadh, Håvard Hegre, Joakim Karlsen and Andrew Linke. 2010. "Introducing ACLED: An Armed Conflict Location and Event Dataset." Journal of Peace Research 47:In press.

Rehn, Elisabeth and Ellen Johnson Sirleaf. 2002. "Women, War, Peace." Report of the United Nations Development Fund for Women.

Ringdal, Gerd Inger, Kristen Ringdal and Albert Simkus. 2008. "War-Related Distress Among Kosovar Albanians." Journal of Loss and Trauma 13:59-71.

Salehyan, Idean and Kristian S. Gleditsch. 2006. "Refugees and the Spread of Civil War." International Organization 60(2):335-366.

Sapir, Debarati Guha and Vicente Teran Gomez. 2006. "Angola: The Human Impact of War - A data review of field surveys between 1999-2005." Report of the Centre for Research on the Epidemiology of Disasters (CRED), Brussels.

Spiegel, Paul B, Anne R Bennedsen, Johanna Claass, Laurie Bruns, Njogu Patterson, Dieudonne Yiweza and Marian Schilperoord. 2007. "Prevalence of HIV Infection in Conflict-Affected and Displaced People in Seven Sub-Saharan African Countries: A Systematic Review." The Lancet 369:2187-2195.

Stewart, Frances, Frank P. Humphreys and Nick Lea. 1997. "Civil Conflict in Developing Countries over the Last Quarter of a Century: An Empirical Overview of Economic and Social Consequences." Oxford Development Studies 25:11-41.

Strabac, Zan and Kristen Ringdal. 2008. "Individual and Contextual Influences of War on Ethnic Prejudice in Croatia." The Sociological Quarterly 49:769-796.

Strand, Roland T., L. Fernandes Dias, S. Bergström and S. Andersson. 2007. "Unexpected Low Prevalence of HIV Among Fertile Women in Luanda, Angola. Does War Prevent the Spread of HIV?" International Journal of STD \& AIDS 18:467-471.

Tukey, J. W. 1977. Exploratory Data Analysis. Reading, MA: Addison-Wesley.

United Nations. 2007. World Population Prospects. The 2006 Revision. Number 202.

United Nations. 2009. The Millennium Development Goals Report. New York: United Nations.

World Bank. 1978. World Development Report. Washington, DC: The International Bank for Reconstruction and Development.

World Bank. 1990. World Development Report 1990: Poverty. Washington, DC: The International Bank for Reconstruction and Development.

World Bank. 2007. Global Monitoring Report 200\%. Washington, DC: The International Bank for Reconstruction and Development. 


\section{A Appendix}

\section{A.1 List of countries}

Table A-1: Countries included in analysis, classified by category, 2008

\begin{tabular}{|c|c|c|}
\hline Conflict & Fragile & Post-conflict or post-fragile \\
\hline Afghanistan & Angola & Azerbaijan \\
\hline Algeria & Bosnia and Herzegovina & Cambodia \\
\hline Burundi & Cameroon & Equatorial Guinea \\
\hline Chad & Central African Republic & Ethiopia \\
\hline Colombia & Comoros & Korea, Dem. Rep. \\
\hline Congo, Dem. Rep. & Congo, Rep. & Lao PDR \\
\hline Iraq & Cote d'Ivoire & Macedonia, FYR \\
\hline Israel & Djibouti & Moldova \\
\hline Liberia & Eritrea & Mozambique \\
\hline Nepal & Gambia, The & Nicaragua \\
\hline Pakistan & Guinea & Niger \\
\hline Philippines & Guinea-Bissau & Nigeria \\
\hline Russian Federation & Haiti & Peru \\
\hline Somalia & Myanmar & Rwanda \\
\hline Sri Lanka & Papua New Guinea & Senegal \\
\hline Sudan & Sierra Leone & Serbia \\
\hline Thailand & Solomon Islands & Uzbekistan \\
\hline Turkey & Tajikistan & \\
\hline Uganda & Timor-Leste & \\
\hline & Togo & \\
\hline & Yemen, Rep. & \\
\hline \multicolumn{3}{|c|}{ Neither conflict nor fragile } \\
\hline Albania & Fiji & Namibia \\
\hline Argentina & Gabon & \\
\hline Armenia & Ghana & Oman \\
\hline Bahamas, The & Guatemala & Panama \\
\hline Bahrain & Guyana & Paraguay \\
\hline Bangladesh & Honduras & Poland \\
\hline Barbados & Hungary & Qatar \\
\hline Belarus & Jamaica & Romania \\
\hline Belize & Jordan & Saudi Arabia \\
\hline Benin & Kazakhstan & Singapore \\
\hline Bhutan & Kenya & Slovak Republic \\
\hline Bolivia & Korea, Rep. & Slovenia \\
\hline Botswana & Kuwait & South Africa \\
\hline Brazil & Kyrgyz Republic & Suriname \\
\hline Brunei Darussalam & Latvia & Swaziland \\
\hline Bulgaria & Lebanon & Syrian Arab Republic \\
\hline & Lesotho & \\
\hline Burkina Faso & Libya & Taiwan, China \\
\hline Cape Verde & Lithuania & Tanzania \\
\hline Chile & Madagascar & Trinidad and Tobago \\
\hline Costa Rica & Malawi & Tunisia \\
\hline Croatia & Malaysia & Turkmenistan \\
\hline Cuba & Maldives & Ukraine \\
\hline Cyprus & Malta & United Arab Emirates \\
\hline Czech Republic & Mauritania & Uruguay \\
\hline Dominican Republic & Mauritius & Venezuela, RB \\
\hline Ecuador & Mexico & Vietnam \\
\hline Egypt & Mongolia & Zambia \\
\hline El Salvador & Montenegro & \\
\hline Estonia & Morocco & \\
\hline \multicolumn{3}{|l|}{ India/China } \\
\hline India & China & \\
\hline
\end{tabular}




\section{A.2 List of conflict country matches}

Table A-2: Conflict country matches

\begin{tabular}{|l|l|l|}
\hline Year & Name of conflict country & Name of matching country \\
\hline 1971 & Cameroon & Madagascar (Malagasy) \\
1973 & Syria & Zimbabwe (Rhodesia) \\
1978 & El Salvador & Nicaragua \\
1979 & Tunisia & Syria \\
1980 & Cote d'Ivoire & Tunisia \\
1981 & Chile & Malaysia \\
1989 & Burkina Faso (Upper Volta) & Chad \\
1990 & Burkina Faso (Upper Volta) & Mali \\
1990 & Gabon & Trinidad and Tobago \\
1990 & Niger & Mali \\
1991 & Burkina Faso (Upper Volta) & Burundi \\
1991 & Malawi & Burundi \\
1994 & Malawi & Burundi \\
1994 & Rwanda & Burundi \\
1996 & Togo & Central African Republic \\
1998 & France & United Kingdom \\
1998 & Gambia & Lesotho \\
1998 & Mauritania & Lesotho \\
2007 & Burkina Faso (Upper Volta) & Mali \\
2008 & Armenia & Georgia \\
2008 & Egypt & Iran (Persia) \\
\hline
\end{tabular}




\section{A.3 Regression Results}

\section{A.3.1 MDG 1: Ending Poverty and Hunger}

\section{Cross-sectional analyses}

Table A-3: Improvement in nourishment, Cross-section 1990-2004

\begin{tabular}{|c|c|c|c|c|c|}
\hline & $\begin{array}{c}\text { (1) } \\
\text { improvement }\end{array}$ & $\begin{array}{c}(2) \\
\text { improvement }\end{array}$ & $\begin{array}{c}\text { (3) } \\
\text { improvement }\end{array}$ & $\begin{array}{c}\text { (4) } \\
\text { improvement }\end{array}$ & $\begin{array}{c}(5) \\
\text { improvement }\end{array}$ \\
\hline exposure & $\begin{array}{l}-0.493 \\
(0.510)\end{array}$ & $\begin{array}{l}-0.608 \\
(0.475)\end{array}$ & $\begin{array}{l}-0.519 \\
(0.499)\end{array}$ & $\begin{array}{l}-0.564 \\
(0.487)\end{array}$ & $\begin{array}{l}-0.376 \\
(0.504)\end{array}$ \\
\hline (firstnm) undernourish & $\begin{array}{c}-0.379 * * * \\
(0.0520)\end{array}$ & $\begin{array}{c}-0.397^{* * *} * \\
(0.0471)\end{array}$ & $\begin{array}{c}-0.409 * * * \\
(0.0524)\end{array}$ & $\begin{array}{c}-0.461 * * * \\
(0.0551)\end{array}$ & $\begin{array}{c}-0.379 * * * \\
(0.0495)\end{array}$ \\
\hline logged total population & $\begin{array}{l}0.0602 \\
(0.453)\end{array}$ & $\begin{array}{l}-0.354 \\
(0.414)\end{array}$ & $\begin{array}{l}-0.126 \\
(0.438)\end{array}$ & $\begin{array}{c}0.301 \\
(0.410)\end{array}$ & $\begin{array}{c}0.343 \\
(0.436)\end{array}$ \\
\hline $\begin{array}{l}\text { (sum) minor } \\
\text { (sum) war }\end{array}$ & $\begin{array}{c}0.0644 \\
(0.233) \\
0.140 \\
(0.349)\end{array}$ & & & & \\
\hline $\mathrm{bd} 1 \mathrm{k}$ & & $\begin{array}{c}0.151^{* * * *} \\
(0.0354)\end{array}$ & & & \\
\hline $\operatorname{lnbd}$ & & & $\begin{array}{c}0.385^{* *} \\
(0.188)\end{array}$ & & \\
\hline (sum) fsida & & & & $\begin{array}{c}0.498 * * * \\
(0.152)\end{array}$ & \\
\hline$($ sum) cpia & & & & & $\begin{array}{c}-0.0579 \\
(0.0350)\end{array}$ \\
\hline Constant & $\begin{array}{c}8.682 \\
(9.200)\end{array}$ & $\begin{array}{c}13.78 \\
(8.557)\end{array}$ & $\begin{array}{c}9.953 \\
(8.936)\end{array}$ & $\begin{array}{c}8.253 \\
(8.658)\end{array}$ & $\begin{array}{c}6.188 \\
(8.962)\end{array}$ \\
\hline $\mathrm{N}$ & 141 & 141 & 141 & 141 & 141 \\
\hline Start & 1990.4 & 1990.4 & 1990.4 & 1990.4 & 1990.4 \\
\hline End & 2004.9 & 2004.9 & 2004.9 & 2004.9 & 2004.9 \\
\hline $\mathrm{r} 2$ & 0.324 & 0.405 & 0.343 & 0.374 & 0.336 \\
\hline
\end{tabular}

Standard errors in parentheses
$* p<0.10,{ }^{* *} p<0.05,{ }^{* * *} p<0.01$

Table A-4: Improvement in poverty headcount, Cross-section 1991-2003

\begin{tabular}{|c|c|c|c|c|c|}
\hline & $\begin{array}{c}(1) \\
\text { improvement }\end{array}$ & $\begin{array}{c}(2) \\
\text { improvement }\end{array}$ & $\begin{array}{c}(3) \\
\text { improvement }\end{array}$ & $\begin{array}{c}(4) \\
\text { improvement }\end{array}$ & $\begin{array}{c}(5) \\
\text { improvement }\end{array}$ \\
\hline exposure & $\begin{array}{c}-0.511^{* * *} \\
(0.167)\end{array}$ & $\begin{array}{c}-0.486^{* * *} * \\
(0.162)\end{array}$ & $\begin{array}{c}-0.555^{* * *} * \\
(0.162)\end{array}$ & $\begin{array}{c}-0.575^{* * *} * \\
(0.151)\end{array}$ & $\begin{array}{c}0.214 \\
(0.405)\end{array}$ \\
\hline (firstnm) poverty & $\begin{array}{c}-0.398 * * * \\
(0.0565)\end{array}$ & $\begin{array}{c}-0.405 * * * \\
(0.0549)\end{array}$ & $\begin{array}{c}-0.408 * * * \\
(0.0537)\end{array}$ & $\begin{array}{c}-0.451^{* * *} \\
(0.0519)\end{array}$ & $\begin{array}{c}-0.414^{* * *} * \\
(0.0540)\end{array}$ \\
\hline logged total population & $\begin{array}{c}-0.0905 \\
(0.851)\end{array}$ & $\begin{array}{l}0.0906 \\
(0.856)\end{array}$ & $\begin{array}{l}-0.186 \\
(0.829)\end{array}$ & $\begin{array}{c}0.581 \\
(0.774)\end{array}$ & $\begin{array}{c}-0.00175 \\
(0.817)\end{array}$ \\
\hline (sum) minor & $\begin{array}{l}0.0327 \\
(0.375)\end{array}$ & & & & \\
\hline (sum) war & $\begin{array}{c}0.548 \\
(0.592)\end{array}$ & & & & \\
\hline $\mathrm{bd} 1 \mathrm{k}$ & & $\begin{array}{c}0.0174 \\
(0.0591)\end{array}$ & & & \\
\hline $\operatorname{lnbd}$ & & & $\begin{array}{c}0.558^{* *} \\
(0.279)\end{array}$ & & \\
\hline (sum) fsida & & & & $\begin{array}{c}1.272^{* * * *} \\
(0.313)\end{array}$ & \\
\hline (sum) cpia & & & & & $\begin{array}{l}-0.183^{*} \\
(0.0985)\end{array}$ \\
\hline Constant & $\begin{array}{c}11.75 \\
(7.949) \\
\end{array}$ & $\begin{array}{c}10.06 \\
(8.010)\end{array}$ & $\begin{array}{c}10.66 \\
(7.591) \\
\end{array}$ & $\begin{array}{c}5.452 \\
(7.224) \\
\end{array}$ & $\begin{array}{r}9.113 \\
(7.588) \\
\end{array}$ \\
\hline $\mathrm{N}$ & 114 & 114 & 114 & 114 & 114 \\
\hline Start & 1991.7 & 1991.7 & 1991.7 & 1991.7 & 1991.7 \\
\hline End & 2003.3 & 2003.3 & 2003.3 & 2003.3 & 2003.3 \\
\hline r2 & 0.506 & 0.499 & 0.518 & 0.568 & 0.515 \\
\hline
\end{tabular}

Standard errors in parentheses

$* p<0.10, * * p<0.05, * * * x<0.01$ 
Table A-5: Improvement in life expectancy, 1967-2007

\begin{tabular}{|c|c|c|c|c|c|}
\hline & $\begin{array}{c}(1) \\
\text { improvement }\end{array}$ & $\begin{array}{c}(2) \\
\text { improvement }\end{array}$ & $\begin{array}{c}\text { (3) } \\
\text { improvement }\end{array}$ & $\begin{array}{c}(4) \\
\text { improvement }\end{array}$ & $\begin{array}{c}(5) \\
\text { improvement }\end{array}$ \\
\hline exposure & $\begin{array}{c}0.222^{* * *} \\
(0.0513)\end{array}$ & $\begin{array}{c}0.223^{* * *} \\
(0.0493)\end{array}$ & $\begin{array}{c}0.225^{* * *} \\
(0.0513)\end{array}$ & $\begin{array}{c}0.204^{* * *} \\
(0.0497)\end{array}$ & $\begin{array}{l}0.209^{* * *} \\
(0.0523)\end{array}$ \\
\hline (firstnm) lifeexpec & $\begin{array}{c}-0.606 * * * \\
(0.0604)\end{array}$ & $\begin{array}{c}-0.621^{* * *} * \\
(0.0583)\end{array}$ & $\begin{array}{c}-0.617^{* * *} \\
(0.0616)\end{array}$ & $\begin{array}{c}-0.681 * * * \\
(0.0626)\end{array}$ & $\begin{array}{c}-0.574^{* * *} \\
(0.0608)\end{array}$ \\
\hline logged total population & $\begin{array}{l}-0.168 \\
(0.299)\end{array}$ & $\begin{array}{l}-0.112 \\
(0.270)\end{array}$ & $\begin{array}{l}-0.0536 \\
(0.301)\end{array}$ & $\begin{array}{l}-0.498^{*} \\
(0.269)\end{array}$ & $\begin{array}{l}-0.415 \\
(0.281)\end{array}$ \\
\hline $\begin{array}{l}(\text { sum }) \text { minor } \\
(\text { sum) war }\end{array}$ & $\begin{array}{c}0.0128 \\
(0.0571) \\
-0.221^{* * *} \\
(0.0827)\end{array}$ & & & & \\
\hline bd1k & & $\begin{array}{c}-0.0228 * * * \\
(0.00540)\end{array}$ & & & \\
\hline $\operatorname{lnbd}$ & & & $\begin{array}{c}-0.249^{* *} \\
(0.107)\end{array}$ & & \\
\hline (sum) fsida & & & & $\begin{array}{c}-0.197^{* * *} \\
(0.0487)\end{array}$ & \\
\hline (sum) cpia & & & & & $\begin{array}{l}0.0207^{*} \\
(0.0114)\end{array}$ \\
\hline Constant & $\begin{array}{c}43.60 * * * \\
(5.253)\end{array}$ & $\begin{array}{c}44.42 * * * \\
(5.018)\end{array}$ & $\begin{array}{c}44.36 * * * \\
(5.237)\end{array}$ & $\begin{array}{c}50.90 * * * \\
(5.368)\end{array}$ & $\begin{array}{c}43.11^{* * *} \\
(5.260)\end{array}$ \\
\hline $\mathrm{N}$ & 153 & 153 & 153 & 153 & 153 \\
\hline Start & 1967.6 & 1967.6 & 1967.6 & 1967.6 & 1967.6 \\
\hline End & 2007.2 & 2007.2 & 2007.2 & 2007.2 & 2007.2 \\
\hline $\mathrm{r} 2$ & 0.733 & 0.750 & 0.729 & 0.748 & 0.725 \\
\hline
\end{tabular}

${ }^{*} p<0.10,{ }^{* *} p<0.05,{ }^{* * *} p<0.01$

Table A-6: Improvement in log GDP per capita, 1972-2007

\begin{tabular}{|c|c|c|c|c|c|}
\hline & $\begin{array}{c}\text { (1) } \\
\text { improvement }\end{array}$ & $\begin{array}{c}(2) \\
\text { improvement }\end{array}$ & $\begin{array}{c}(3) \\
\text { improvement }\end{array}$ & $\begin{array}{c}(4) \\
\text { improvement }\end{array}$ & $\begin{array}{c}(5) \\
\text { improvement }\end{array}$ \\
\hline exposure & $\begin{array}{l}0.0138^{* *} \\
(0.00640)\end{array}$ & $\begin{array}{l}0.0127 * * \\
(0.00619)\end{array}$ & $\begin{array}{c}0.0171 * * * \\
(0.00623)\end{array}$ & $\begin{array}{c}0.0123^{* *} \\
(0.00553)\end{array}$ & $\begin{array}{c}0.0107 \\
(0.00663)\end{array}$ \\
\hline (firstnm) gdp_capita & $\begin{array}{c}-0.429 * * * \\
(0.0653)\end{array}$ & $\begin{array}{c}-0.430 * * * \\
(0.0652)\end{array}$ & $\begin{array}{c}-0.446 * * * \\
(0.0634)\end{array}$ & $\begin{array}{c}-0.501 * * * \\
(0.0594)\end{array}$ & $\begin{array}{c}-0.412^{* * *} \\
(0.0696)\end{array}$ \\
\hline logged total population & $\begin{array}{l}-0.0943^{*} \\
(0.0498)\end{array}$ & $\begin{array}{c}-0.0986 * * \\
(0.0494)\end{array}$ & $\begin{array}{l}-0.0512 \\
(0.0481)\end{array}$ & $\begin{array}{c}-0.133^{* * *} * \\
(0.0407)\end{array}$ & $\begin{array}{c}-0.110^{* *} \\
(0.0455)\end{array}$ \\
\hline (sum) minor & $\begin{array}{l}-0.00727 \\
(0.00996)\end{array}$ & & & & \\
\hline (sum) war & $\begin{array}{c}0.000855 \\
(0.0188)\end{array}$ & & & & \\
\hline $\mathrm{bd} 1 \mathrm{k}$ & & $\begin{array}{r}-0.000713 \\
(0.00201)\end{array}$ & & & \\
\hline $\operatorname{lnbd}$ & & & $\begin{array}{c}-0.0505^{* * *} \\
(0.0181)\end{array}$ & & \\
\hline (sum) fsida & & & & $\begin{array}{c}-0.0481 * * * \\
(0.00830)\end{array}$ & \\
\hline (sum) cpia & & & & & $\begin{array}{c}0.00177 \\
(0.00232)\end{array}$ \\
\hline Constant & $\begin{array}{c}4.311 * * * \\
(0.799)\end{array}$ & $\begin{array}{c}4.353^{* * * *} \\
(0.796)\end{array}$ & $\begin{array}{c}4.200 * * * \\
(0.753)\end{array}$ & $\begin{array}{c}5.253 * * * \\
(0.705)\end{array}$ & $\begin{array}{c}4.299 * * * \\
(0.786)\end{array}$ \\
\hline $\mathrm{N}$ & 148 & 148 & 148 & 148 & 148 \\
\hline Start & 1972.1 & 1972.1 & 1972.1 & 1972.1 & 1972.1 \\
\hline End & 2007.7 & 2007.7 & 2007.7 & 2007.7 & 2007.7 \\
\hline $\mathrm{r} 2$ & 0.363 & 0.361 & 0.394 & 0.486 & 0.363 \\
\hline
\end{tabular}

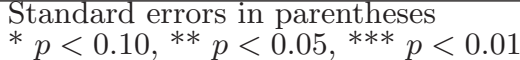




\section{Fixed-effects models}

Table A-7: Fixed-Effects Analysis, Undernourishment, 1992-2005

\begin{tabular}{|c|c|c|c|c|c|c|}
\hline & Conflict & Battle Deaths & BD*Pop. & Fragility & CPIA & $\mathrm{PCSE}, \operatorname{AR}(1)$ \\
\hline $1975-79$ & $\begin{array}{c}0 \\
(0)\end{array}$ & $\begin{array}{c}0 \\
(0)\end{array}$ & $\begin{array}{c}0 \\
(0)\end{array}$ & $\begin{array}{c}0 \\
(0)\end{array}$ & $\begin{array}{c}0 \\
(0)\end{array}$ & $\begin{array}{c}0 \\
(0)\end{array}$ \\
\hline $1980-84$ & 0 & 0 & 0 & 0 & 0 & 0 \\
\hline & $(0)$ & $(0)$ & $(0)$ & $(0)$ & $(0)$ & $(0)$ \\
\hline $1985-89$ & $\begin{array}{c}0 \\
(0)\end{array}$ & $\begin{array}{c}0 \\
(0)\end{array}$ & $\begin{array}{c}0 \\
(0)\end{array}$ & $\begin{array}{c}0 \\
(0)\end{array}$ & $\begin{array}{c}0 \\
(0)\end{array}$ & $\begin{array}{c}0 \\
(0)\end{array}$ \\
\hline 1990-94 & $\begin{array}{c}0 \\
(0)\end{array}$ & $\begin{array}{c}0 \\
(0)\end{array}$ & $\begin{array}{c}0 \\
(0)\end{array}$ & $\begin{array}{c}0 \\
(0)\end{array}$ & $\begin{array}{c}0 \\
(0)\end{array}$ & $\begin{array}{c}0 \\
(0)\end{array}$ \\
\hline 1995-99 & $\begin{array}{c}0 \\
(0)\end{array}$ & $\begin{array}{l}0 \\
(0)\end{array}$ & $\begin{array}{c}0 \\
(0)\end{array}$ & $\begin{array}{c}0 \\
(0)\end{array}$ & $\begin{array}{c}0 \\
(0)\end{array}$ & $\begin{array}{c}15.63^{* * *} \\
(2.624)\end{array}$ \\
\hline $2000-04$ & $\begin{array}{l}-0.894 \\
(0.578)\end{array}$ & $\begin{array}{l}-0.830 \\
(0.580)\end{array}$ & $\begin{array}{l}-0.788 \\
(0.581)\end{array}$ & $\begin{array}{c}-1.078^{*} \\
(0.508)\end{array}$ & $\begin{array}{l}-0.993 \\
(0.617)\end{array}$ & $\begin{array}{c}14.60^{* * * *} \\
(2.524)\end{array}$ \\
\hline $2005-08$ & $\begin{array}{c}-2.324^{* *} \\
(0.834)\end{array}$ & $\begin{array}{c}-2.209^{* *} \\
(0.838)\end{array}$ & $\begin{array}{c}-2.158^{*} \\
(0.839)\end{array}$ & $\begin{array}{c}-2.520^{* * *} \\
(0.681)\end{array}$ & $\begin{array}{c}-2.713^{* * *} \\
(0.803)\end{array}$ & $\begin{array}{c}13.54^{* * *} * \\
(2.533)\end{array}$ \\
\hline Log of Population & $\begin{array}{c}-2.299 \\
(3.750)\end{array}$ & $\begin{array}{l}-3.036 \\
(3.749)\end{array}$ & $\begin{array}{l}-3.579 \\
(3.788)\end{array}$ & $\begin{array}{l}-2.269 \\
(3.371)\end{array}$ & $\begin{array}{l}-2.971 \\
(4.019)\end{array}$ & $\begin{array}{l}0.0581 \\
(0.323)\end{array}$ \\
\hline Conflict_t-1 & $\begin{array}{c}0.697^{* * *} \\
(0.167)\end{array}$ & & & & & $\begin{array}{l}1.114^{* *} \\
(0.385)\end{array}$ \\
\hline Conflict in Neighbourhood & $\begin{array}{c}-0.0923 \\
(0.111)\end{array}$ & $\begin{array}{l}-0.128 \\
(0.111)\end{array}$ & $\begin{array}{l}-0.121 \\
(0.111)\end{array}$ & & & $\begin{array}{c}0.257 \\
(0.215)\end{array}$ \\
\hline Log of Battle Deaths _t-1 & & $\begin{array}{c}0.416^{* * *} \\
(0.106)\end{array}$ & $\begin{array}{c}0.365^{* *} \\
(0.117)\end{array}$ & & & \\
\hline Log of Battle Deaths _t-1 X Log of Population & & & $\begin{array}{c}0.0822 \\
(0.0816)\end{array}$ & & & \\
\hline Fragility & & & & $\begin{array}{c}0.608 \\
(1.237)\end{array}$ & & \\
\hline Cumulative CPIA Score & & & & & $\begin{array}{c}0.566 \\
(0.605)\end{array}$ & \\
\hline Constant & $\begin{array}{l}39.50 \\
(33.41)\end{array}$ & $\begin{array}{c}46.26 \\
(33.38)\end{array}$ & $\begin{array}{c}51.00 \\
(33.71)\end{array}$ & $\begin{array}{c}39.21 \\
(30.08)\end{array}$ & $\begin{array}{c}46.15 \\
(36.82)\end{array}$ & $\begin{array}{c}0 \\
(0)\end{array}$ \\
\hline Observations & 395 & 395 & 395 & 414 & 343 & 395 \\
\hline $\begin{array}{l}\text { Log likelihood } \\
\chi^{2}\end{array}$ & -939.5 & -941.0 & -940.2 & -1016.5 & -857.4 & 3242.8 \\
\hline
\end{tabular}

${ }^{*} p<0.05,{ }^{* *} p<0.01,{ }^{* * *} p<0.001$

Table A-8: Fixed-Effects Analysis, Poverty Rates, 1980-2005

\begin{tabular}{|c|c|c|c|c|c|c|}
\hline & Conflict & Battle Deaths & BD*Pop. & Fragility & CPIA & PCSE, $\operatorname{AR}(1)$ \\
\hline $1975-79$ & $\begin{array}{c}0 \\
(0)\end{array}$ & $\begin{array}{c}0 \\
(0)\end{array}$ & $\begin{array}{c}0 \\
(0)\end{array}$ & $\begin{array}{c}0 \\
(0)\end{array}$ & $\begin{array}{c}0 \\
(0)\end{array}$ & $\begin{array}{c}0 \\
(0)\end{array}$ \\
\hline $1980-84$ & 0 & 0 & 0 & -0.0156 & -0.984 & 0 \\
\hline $1985-89$ & $\begin{array}{c}(0) \\
-0.0476\end{array}$ & $\begin{array}{c}(0) \\
-0.801 \\
(4-156)\end{array}$ & $\begin{array}{c}(0) \\
-1.548\end{array}$ & $\begin{array}{c}(4.098) \\
0\end{array}$ & $\begin{array}{c}(4.197) \\
0\end{array}$ & $\begin{array}{c}(0) \\
-9.473 \\
(5-011)\end{array}$ \\
\hline $1990-94$ & $\begin{array}{l}(4.184) \\
-0.815 \\
(4.348)\end{array}$ & $\begin{array}{c}(4.156) \\
-1.725 \\
(4.273)\end{array}$ & $\begin{array}{l}(4.154) \\
-2.332 \\
(4.263)\end{array}$ & $\begin{array}{c}(0) \\
-0.633 \\
(1.855)\end{array}$ & $\begin{array}{c}(0) \\
-0.829 \\
(2.032)\end{array}$ & $\begin{array}{c}(5.911) \\
-11.58 \\
(7.312)\end{array}$ \\
\hline 1995-99 & $\begin{array}{l}-2.363 \\
(4.511)\end{array}$ & $\begin{array}{l}-3.425 \\
(4.422)\end{array}$ & $\begin{array}{l}-4.143 \\
(4.415)\end{array}$ & $\begin{array}{l}-2.167 \\
(1.979)\end{array}$ & $\begin{array}{l}-1.931 \\
(2.404)\end{array}$ & $\begin{array}{l}-11.87 \\
(6.868)\end{array}$ \\
\hline 2000-04 & $\begin{array}{c}-3.019 \\
(4.802)\end{array}$ & $\begin{array}{l}-4.201 \\
(4.697)\end{array}$ & $\begin{array}{l}-4.899 \\
(4.688)\end{array}$ & $\begin{array}{c}-2.773 \\
(2.240)\end{array}$ & $\begin{array}{l}-2.199 \\
(2.869)\end{array}$ & $\begin{array}{l}-13.20 \\
(6.900)\end{array}$ \\
\hline $2005-08$ & $\begin{array}{l}-6.063 \\
(5.050)\end{array}$ & $\begin{array}{l}-7.168 \\
(4.920)\end{array}$ & $\begin{array}{l}-7.978 \\
(4.914)\end{array}$ & $\begin{array}{l}-6.122^{*} \\
(2.605)\end{array}$ & $\begin{array}{l}-5.486 \\
(3.394)\end{array}$ & $\begin{array}{l}-17.59^{*} \\
(7.506)\end{array}$ \\
\hline Log of Population & $\begin{array}{c}-10.60 \\
(5.893)\end{array}$ & $\begin{array}{l}-8.822 \\
(5.754)\end{array}$ & $\begin{array}{l}-8.278 \\
(5.730)\end{array}$ & $\begin{array}{l}-10.49 \\
(5.378)\end{array}$ & $\begin{array}{c}-15.16^{*} \\
(7.519)\end{array}$ & $\begin{array}{c}0.259 \\
(1.408)\end{array}$ \\
\hline Conflict _t-1 & $\begin{array}{l}-0.156 \\
(0.271)\end{array}$ & & & & & $\begin{array}{l}0.691^{*} \\
(0.294)\end{array}$ \\
\hline Conflict in Neighbourhood & $\begin{array}{l}0.205 \\
(0.184)\end{array}$ & $\begin{array}{c}0.221 \\
(0.184)\end{array}$ & $\begin{array}{c}0.250 \\
(0.184)\end{array}$ & & & $\begin{array}{c}0.649 \\
(0.363)\end{array}$ \\
\hline Log of Battle Deaths _t-1 & & $\begin{array}{c}0.0982 \\
(0.191)\end{array}$ & $\begin{array}{l}-0.129 \\
(0.231)\end{array}$ & & & \\
\hline Log of Battle Deaths _t-1 X Log of Population & & & $\begin{array}{c}0.198 \\
(0.114)\end{array}$ & & & \\
\hline Fragility & & & & $\begin{array}{l}0.987 \\
(2.234)\end{array}$ & & \\
\hline Cumulative CPIA Score & & & & & $\begin{array}{c}0.257 \\
(0.854)\end{array}$ & \\
\hline Constant & $\begin{array}{l}130.8^{*} \\
(55.07)\end{array}$ & $\begin{array}{l}114.1^{*} \\
(53.87)\end{array}$ & $\begin{array}{l}109.1^{*} \\
(53.63)\end{array}$ & $\begin{array}{l}129.4^{*} \\
(50.82)\end{array}$ & $\begin{array}{l}174.0^{*} \\
(70.74)\end{array}$ & $\begin{array}{l}32.71^{*} \\
(14.62)\end{array}$ \\
\hline Observations & 278 & 278 & 278 & 290 & 278 & 278 \\
\hline $\begin{array}{l}\text { Log likelihood } \\
\chi^{2}\end{array}$ & -827.9 & -827.9 & -825.5 & -864.0 & -828.5 & 11.99 \\
\hline
\end{tabular}

${ }^{*} p<0.05,{ }^{* *} p<0.01,{ }^{* * *} p<0.001$ 
Table A-9: Fixed-Effects Analysis, Life Expectancy, 1970-2005

\begin{tabular}{|c|c|c|c|c|c|c|}
\hline & Conflict & Battle Deaths & BD*Pop. & Fragility & CPIA & PCSE, $\operatorname{AR}(1)$ \\
\hline $1975-79$ & $\begin{array}{c}1.654^{* * *} \\
(0.395)\end{array}$ & $\begin{array}{c}1.714^{* * *} \\
(0.393)\end{array}$ & $\begin{array}{c}1.713^{* * *} \\
(0.392)\end{array}$ & $\begin{array}{c}1.854^{* * * *} \\
(0.379)\end{array}$ & $\begin{array}{c}0 \\
(0)\end{array}$ & $\begin{array}{c}2.149^{* * *} \\
(0.0901)\end{array}$ \\
\hline $1980-84$ & $\begin{array}{c}3.106^{* * *} \\
(0.415)\end{array}$ & $\begin{array}{c}3.171^{* * * *} \\
(0.413)\end{array}$ & $\begin{array}{c}3.113^{* * *} \\
(0.413)\end{array}$ & $\begin{array}{c}3.398^{* * * *} \\
(0.397)\end{array}$ & $\begin{array}{c}-3.194^{* * *} \\
(0.540)\end{array}$ & $\begin{array}{c}4.370^{* * *} \\
(0.132)\end{array}$ \\
\hline $1985-89$ & $\begin{array}{c}4.388^{* * *} \\
(0.463)\end{array}$ & $\begin{array}{c}4.447^{* * *} \\
(0.460)\end{array}$ & $\begin{array}{c}4.362^{* * *} \\
(0.460)\end{array}$ & $\begin{array}{c}4.643^{* * *} \\
(0.434)\end{array}$ & $\begin{array}{c}-1.236^{* *} \\
(0.433)\end{array}$ & $\begin{array}{c}6.427^{* * * *} \\
(0.190)\end{array}$ \\
\hline $1990-94$ & $\begin{array}{c}5.143^{* * *} \\
(0.517)\end{array}$ & $\begin{array}{c}5.202^{* * * *} \\
(0.512)\end{array}$ & $\begin{array}{c}5.114^{* * *} \\
(0.512)\end{array}$ & $\begin{array}{c}5.412^{* * * *} \\
(0.478)\end{array}$ & $\begin{array}{c}0 \\
(0)\end{array}$ & $\begin{array}{c}7.908^{* * *} \\
(0.218)\end{array}$ \\
\hline $1995-99$ & $\begin{array}{c}5.646^{* * *} \\
(0.570)\end{array}$ & $\begin{array}{c}5.734^{* * *} \\
(0.566)\end{array}$ & $\begin{array}{c}5.635^{* * *} \\
(0.566)\end{array}$ & $\begin{array}{c}5.681^{* * *} \\
(0.521)\end{array}$ & $\begin{array}{l}0.905^{*} \\
(0.421)\end{array}$ & $\begin{array}{c}8.954^{* * *} \\
(0.256)\end{array}$ \\
\hline $2000-04$ & $\begin{array}{c}5.885^{* * *} \\
(0.621)\end{array}$ & $\begin{array}{c}5.977^{* * *} \\
(0.617)\end{array}$ & $\begin{array}{c}5.856^{* * *} \\
(0.617)\end{array}$ & $\begin{array}{c}6.125^{* * *} \\
(0.565)\end{array}$ & $\begin{array}{c}1.982^{* * *} \\
(0.491)\end{array}$ & $\begin{array}{c}9.809^{* * *} \\
(0.237)\end{array}$ \\
\hline $2005-08$ & $\begin{array}{c}6.584^{* * *} \\
(0.662)\end{array}$ & $\begin{array}{c}6.658^{* * *} * \\
(0.657)\end{array}$ & $\begin{array}{c}6.500^{* * *} \\
(0.659)\end{array}$ & $\begin{array}{c}6.848^{* * *} \\
(0.607)\end{array}$ & $\begin{array}{c}2.897^{* * *} \\
(0.565)\end{array}$ & $\begin{array}{c}10.86^{* * *} \\
(0.266)\end{array}$ \\
\hline Log of Population & $\begin{array}{c}5.435^{* * *} \\
(0.732)\end{array}$ & $\begin{array}{c}5.292^{* * *} \\
(0.729)\end{array}$ & $\begin{array}{c}5.377^{* * *} \\
(0.728)\end{array}$ & $\begin{array}{c}5.355^{* * *} \\
(0.671)\end{array}$ & $\begin{array}{c}0.00203 \\
(1.462)\end{array}$ & $\begin{array}{c}-0.197 \\
(0.229)\end{array}$ \\
\hline Conflict _t-1 & $\begin{array}{c}-0.107 \\
(0.0559)\end{array}$ & & & & & $\begin{array}{c}-0.154^{* *} \\
(0.0522)\end{array}$ \\
\hline Conflict in Neighbourhood & $\begin{array}{c}0.0179 \\
(0.0420)\end{array}$ & $\begin{array}{c}0.0229 \\
(0.0418)\end{array}$ & $\begin{array}{c}0.0263 \\
(0.0417)\end{array}$ & & & $\begin{array}{l}-0.0203 \\
(0.0418)\end{array}$ \\
\hline Log of Battle Deaths _t- 1 & & $\begin{array}{c}-0.124^{* * *} \\
(0.0359)\end{array}$ & $\begin{array}{c}-0.165^{* * *} \\
(0.0399)\end{array}$ & & & \\
\hline Log of Battle Deaths _t-1 X Log of Population & & & $\begin{array}{l}0.0576^{*} \\
(0.0243)\end{array}$ & & & \\
\hline Fragility & & & & $\begin{array}{c}-1.405^{* * *} \\
(0.329)\end{array}$ & & \\
\hline Cumulative CPIA Score & & & & & $\begin{array}{c}0.610^{* *} \\
(0.195)\end{array}$ & \\
\hline Constant & $\begin{array}{c}9.024 \\
(6.158)\end{array}$ & $\begin{array}{c}10.34 \\
(6.136)\end{array}$ & $\begin{array}{c}9.620 \\
(6.127)\end{array}$ & $\begin{array}{c}10.14 \\
(5.614)\end{array}$ & $\begin{array}{c}58.19^{* * *} \\
(13.00)\end{array}$ & $\begin{array}{c}56.82^{* * *} \\
(2.114)\end{array}$ \\
\hline Observations & 1029 & 1029 & 1029 & 1068 & 651 & 1029 \\
\hline $\begin{array}{l}\text { Log likelihood } \\
\chi^{2}\end{array}$ & -2436.1 & -2431.3 & -2428.0 & -2515.0 & -1502.7 & 2930.1 \\
\hline
\end{tabular}

Standard errors in parentheses

${ }^{*} p<0.05,{ }^{* *} p<0.01,{ }^{* * *} p<0.001$ 
Table A-10: Effect of Conflict on Annual Growth in GDP per Capita (PPP, logged), 1960-2005, OLS with Panel-Corrected Standard Errors

\begin{tabular}{|c|c|c|c|c|c|c|}
\hline & $\begin{array}{l}(1) \\
\mathrm{C}\end{array}$ & $\begin{array}{c}(2) \\
\text { C with lags }\end{array}$ & $\begin{array}{c}\text { (3) } \\
\text { C, lags, FE }\end{array}$ & $\begin{array}{l}(4) \\
\mathrm{BD}\end{array}$ & $\begin{array}{c}(5) \\
\text { BD with lags }\end{array}$ & $\begin{array}{l}(6) \\
\text { est6 }\end{array}$ \\
\hline conflict & $\begin{array}{c}-0.0160^{* * *} \\
(0.00303)\end{array}$ & $\begin{array}{c}-0.0178^{* * *} \\
(0.00423)\end{array}$ & & $\begin{array}{c}-0.0168^{* * *} \\
(0.00419)\end{array}$ & & \\
\hline $\operatorname{td} 65$ & $\begin{array}{c}0.0361^{* *} \\
(0.0126)\end{array}$ & $\begin{array}{c}0.0560^{* *} \\
(0.0181)\end{array}$ & $\begin{array}{c}0.0549^{* *} \\
(0.0180)\end{array}$ & $\begin{array}{c}0.0466^{* *} \\
(0.0166)\end{array}$ & $\begin{array}{c}0.0358 * * \\
(0.0126)\end{array}$ & \\
\hline $\mathrm{td} 70$ & $\begin{array}{c}0.0187 \\
(0.0132)\end{array}$ & $\begin{array}{c}0.0211 \\
(0.0175)\end{array}$ & $\begin{array}{c}0.0204 \\
(0.0174)\end{array}$ & $\begin{array}{c}0.0163 \\
(0.0159)\end{array}$ & $\begin{array}{c}0.0186 \\
(0.0132)\end{array}$ & \\
\hline $\operatorname{td} 75$ & $\begin{array}{l}0.00353 \\
(0.0131)\end{array}$ & $\begin{array}{l}0.00517 \\
(0.0172)\end{array}$ & $\begin{array}{l}0.00379 \\
(0.0171)\end{array}$ & $\begin{array}{l}0.00236 \\
(0.0157)\end{array}$ & $\begin{array}{l}0.00290 \\
(0.0132)\end{array}$ & \\
\hline $\operatorname{td} 80$ & $\begin{array}{l}-0.0101 \\
(0.0128)\end{array}$ & $\begin{array}{c}-0.00662 \\
(0.0169)\end{array}$ & $\begin{array}{c}-0.00800 \\
(0.0168)\end{array}$ & $\begin{array}{l}-0.0119 \\
(0.0156)\end{array}$ & $\begin{array}{l}-0.0113 \\
(0.0128)\end{array}$ & \\
\hline $\operatorname{td} 85$ & $\begin{array}{r}-0.00727 \\
(0.0125)\end{array}$ & $\begin{array}{r}-0.00553 \\
(0.0166)\end{array}$ & $\begin{array}{r}-0.00678 \\
(0.0165)\end{array}$ & $\begin{array}{r}-0.00981 \\
(0.0154)\end{array}$ & $\begin{array}{r}-0.00839 \\
(0.0126)\end{array}$ & \\
\hline td90 & $\begin{array}{l}-0.0206 \\
(0.0124)\end{array}$ & $\begin{array}{c}-0.00998 \\
(0.0165)\end{array}$ & $\begin{array}{l}-0.0111 \\
(0.0164)\end{array}$ & $\begin{array}{l}-0.0156 \\
(0.0155)\end{array}$ & $\begin{array}{l}-0.0221 \\
(0.0124)\end{array}$ & \\
\hline td95 & $\begin{array}{l}0.00807 \\
(0.0122)\end{array}$ & $\begin{array}{l}0.00834 \\
(0.0164)\end{array}$ & $\begin{array}{l}0.00738 \\
(0.0163)\end{array}$ & $\begin{array}{l}0.00237 \\
(0.0154)\end{array}$ & $\begin{array}{l}0.00695 \\
(0.0122)\end{array}$ & \\
\hline $\operatorname{td} 00$ & $\begin{array}{c}0.0132 \\
(0.0122)\end{array}$ & $\begin{array}{c}0.0152 \\
(0.0163)\end{array}$ & $\begin{array}{c}0.0147 \\
(0.0162)\end{array}$ & $\begin{array}{l}0.00538 \\
(0.0154)\end{array}$ & $\begin{array}{c}0.0127 \\
(0.0122)\end{array}$ & \\
\hline $\operatorname{td} 05$ & $\begin{array}{c}0.0181 \\
(0.0124)\end{array}$ & $\begin{array}{c}0.0193 \\
(0.0166)\end{array}$ & $\begin{array}{c}0.0197 \\
(0.0165)\end{array}$ & $\begin{array}{c}0.0105 \\
(0.0156)\end{array}$ & $\begin{array}{c}0.0186 \\
(0.0124)\end{array}$ & \\
\hline conflict_1 & & $\begin{array}{c}-0.00571 \\
(0.00459)\end{array}$ & $\begin{array}{l}-0.0103^{*} \\
(0.00440)\end{array}$ & $\begin{array}{l}-0.00473 \\
(0.00466)\end{array}$ & & \\
\hline conflict_2 & & $\begin{array}{c}0.00236 \\
(0.00469)\end{array}$ & $\begin{array}{c}-0.000982 \\
(0.00474)\end{array}$ & $\begin{array}{c}0.00300 \\
(0.00473)\end{array}$ & & \\
\hline conflict_3 & & $\begin{array}{c}-0.000136 \\
(0.00482)\end{array}$ & $\begin{array}{l}-0.00272 \\
(0.00487)\end{array}$ & $\begin{array}{c}-0.000121 \\
(0.00482)\end{array}$ & & \\
\hline conflict_4 & & $\begin{array}{c}0.00406 \\
(0.00477)\end{array}$ & $\begin{array}{c}0.00292 \\
(0.00486)\end{array}$ & $\begin{array}{c}0.00469 \\
(0.00477)\end{array}$ & & \\
\hline conflict_5 & & $\begin{array}{c}0.00358 \\
(0.00480)\end{array}$ & $\begin{array}{c}0.00287 \\
(0.00488)\end{array}$ & $\begin{array}{c}0.00435 \\
(0.00484)\end{array}$ & & \\
\hline conflict_6 & & $\begin{array}{c}0.00296 \\
(0.00480)\end{array}$ & $\begin{array}{c}0.00223 \\
(0.00486)\end{array}$ & $\begin{array}{c}0.00398 \\
(0.00483)\end{array}$ & & \\
\hline conflict_7 & & $\begin{array}{c}-0.00122 \\
(0.00483)\end{array}$ & $\begin{array}{l}-0.00160 \\
(0.00488)\end{array}$ & $\begin{array}{l}-0.00130 \\
(0.00486)\end{array}$ & & \\
\hline conflict_8 & & $\begin{array}{c}0.00528 \\
(0.00485)\end{array}$ & $\begin{array}{c}0.00431 \\
(0.00489)\end{array}$ & $\begin{array}{c}0.00483 \\
(0.00487)\end{array}$ & & \\
\hline conflict_9 & & $\begin{array}{c}-0.000564 \\
(0.00475)\end{array}$ & $\begin{array}{c}-0.0000236 \\
(0.00481)\end{array}$ & $\begin{array}{l}-0.000683 \\
(0.00480)\end{array}$ & & \\
\hline conflict_10 & & $\begin{array}{c}0.00236 \\
(0.00435)\end{array}$ & $\begin{array}{c}0.00235 \\
(0.00440)\end{array}$ & $\begin{array}{c}0.00193 \\
(0.00430)\end{array}$ & & \\
\hline $\mathrm{bd}$ & & & & & $\begin{array}{c}-0.00220^{* * *} \\
(0.000656)\end{array}$ & $\begin{array}{c}-0.00237^{*} \\
(0.00101)\end{array}$ \\
\hline bd_1 & & & & & & $\begin{array}{l}-0.00111 \\
(0.00108)\end{array}$ \\
\hline bd_2 & & & & & & $\begin{array}{l}0.00215^{*} \\
(0.00109)\end{array}$ \\
\hline bd_3 & & & & & & $\begin{array}{l}-0.00103 \\
(0.00109)\end{array}$ \\
\hline bd_4 & & & & & & $\begin{array}{r}-0.000803 \\
(0.00107)\end{array}$ \\
\hline bd_5 & & & & & & $\begin{array}{l}0.000377 \\
(0.00108)\end{array}$ \\
\hline bd_6 & & & & & & $\begin{array}{c}-0.0000260 \\
(0.00108)\end{array}$ \\
\hline bd_7 & & & & & & $\begin{array}{r}-0.000445 \\
(0.00109)\end{array}$ \\
\hline bd_8 & & & & & & $\begin{array}{c}0.00163 \\
(0.00110)\end{array}$ \\
\hline bd_9 & & & & & & $\begin{array}{c}0.00122 \\
(0.00107)\end{array}$ \\
\hline bd_10 & & & & & & $\begin{array}{c}-0.000501 \\
(0.00100)\end{array}$ \\
\hline Constant & $\begin{array}{c}0.0172 \\
(0.0106)\end{array}$ & $\begin{array}{c}0.0141 \\
(0.0152)\end{array}$ & $\begin{array}{c}0.0143 \\
(0.0151)\end{array}$ & $\begin{array}{c}0.0162 \\
(0.0135)\end{array}$ & $\begin{array}{c}0.0165 \\
(0.0106)\end{array}$ & $\begin{array}{c}0.0225^{* * *} \\
(0.00394)\end{array}$ \\
\hline $\begin{array}{l}\text { Observations } \\
\text { Log likelihood }\end{array}$ & 5956 & 5235 & 5235 & 5235 & 5960 & 5235 \\
\hline$\chi^{2}$ & 81.81 & 91.30 & 59.60 & 32611.0 & 61.81 & 21.05 \\
\hline
\end{tabular}

Standard errors in parentheses

${ }^{*} p<0.05,{ }^{* *} p<0.01,{ }^{* * *} p<0.001$

C: measure. BD: Battle Deaths measure 


\section{A.3.2 MDG 2: Universal Education}

\section{Cross-sectional analyses}

Table A-11: Improvement in primary school education attainment, Cross-section 1992-2005

\begin{tabular}{|c|c|c|c|c|c|}
\hline & $\begin{array}{c}(1) \\
\text { improvement }\end{array}$ & $\begin{array}{c}(2) \\
\text { improvement }\end{array}$ & $\begin{array}{c}\text { (3) } \\
\text { improvement }\end{array}$ & $\begin{array}{c}\text { (4) } \\
\text { improvement }\end{array}$ & $\begin{array}{c}(5) \\
\text { improvement }\end{array}$ \\
\hline exposure & $\begin{array}{c}1.000^{* * *} \\
(0.173)\end{array}$ & $\begin{array}{c}0.992^{* * *} \\
(0.164)\end{array}$ & $\begin{array}{c}1.018^{* * *} \\
(0.160)\end{array}$ & $\begin{array}{c}1.115^{* * *} \\
(0.157)\end{array}$ & $\begin{array}{c}0.836^{* * *} \\
(0.214)\end{array}$ \\
\hline (firstnm) primaryschool & $\begin{array}{c}-0.476 * * * \\
(0.0518)\end{array}$ & $\begin{array}{c}-0.474^{* * *} \\
(0.0498)\end{array}$ & $\begin{array}{c}-0.518^{* * *} \\
(0.0500)\end{array}$ & $\begin{array}{c}-0.539 * * * \\
(0.0488)\end{array}$ & $\begin{array}{c}-0.482^{* * *} \\
(0.0505)\end{array}$ \\
\hline logged total population & $\begin{array}{c}1.488^{* * * *} \\
(0.547)\end{array}$ & $\begin{array}{c}1.691^{* * * *} \\
(0.515)\end{array}$ & $\begin{array}{c}2.041^{* * * *} \\
(0.523)\end{array}$ & $\begin{array}{l}1.180^{* *} \\
(0.474)\end{array}$ & $\begin{array}{c}1.230 * * \\
(0.529)\end{array}$ \\
\hline $\begin{array}{l}\text { (sum) minor } \\
\text { (sum) war }\end{array}$ & $\begin{array}{c}0.0187 \\
(0.325) \\
-0.416 \\
(0.563)\end{array}$ & & & & \\
\hline $\mathrm{bd} 1 \mathrm{k}$ & & $\begin{array}{c}-0.153^{* *} \\
(0.0681)\end{array}$ & & & \\
\hline $\operatorname{lnbd}$ & & & $\begin{array}{c}-0.812^{* * *} \\
(0.239)\end{array}$ & & \\
\hline (sum) fsida & & & & $\begin{array}{c}-0.876^{* * *} \\
(0.187)\end{array}$ & \\
\hline$($ sum) cpia & & & & & $\begin{array}{c}0.0514 \\
(0.0456)\end{array}$ \\
\hline Constant & $\begin{array}{l}18.33^{* * *} \\
(7.313)\end{array}$ & $\begin{array}{l}17.51 * * \\
(7.101)\end{array}$ & $\begin{array}{c}18.57^{* * * *} \\
(6.909)\end{array}$ & $\begin{array}{c}24.74^{* * * *} \\
(6.785)\end{array}$ & $\begin{array}{c}22.07^{* * *} * \\
(7.621)\end{array}$ \\
\hline $\mathrm{N}$ & 147 & 147 & 147 & 147 & 147 \\
\hline Start & 1992.5 & 1992.5 & 1992.5 & 1992.5 & 1992.5 \\
\hline End & 2005.2 & 2005.2 & 2005.2 & 2005.2 & 2005.2 \\
\hline $\mathrm{r} 2$ & 0.553 & 0.567 & 0.586 & 0.613 & 0.555 \\
\hline
\end{tabular}

Standard errors in parentheses

${ }^{*} p<0.10,{ }^{* *} p<0.05,{ }^{* * *} p<0.01$

Table A-12: Improvement in secondary school education enrollment, Cross-section 1973-2008

\begin{tabular}{|c|c|c|c|c|c|}
\hline & $\begin{array}{c}(1) \\
\text { improvement }\end{array}$ & $\begin{array}{c}(2) \\
\text { improvement }\end{array}$ & $\begin{array}{c}(3) \\
\text { improvement }\end{array}$ & $\begin{array}{c}(4) \\
\text { improvement }\end{array}$ & $\begin{array}{c}(5) \\
\text { improvement }\end{array}$ \\
\hline exposure & $0.00472^{* *}$ & $0.00460^{* *}$ & $0.00468^{* *}$ & $0.00442^{* *}$ & $0.00407^{* *}$ \\
\hline & $(0.00187)$ & $(0.00186)$ & $(0.00190)$ & $(0.00186)$ & $(0.00190)$ \\
\hline$($ firstnm) edu & $\begin{array}{c}-0.317^{* * * *} \\
(0.0584)\end{array}$ & $\begin{array}{c}-0.328^{* * * *} \\
(0.0582)\end{array}$ & $\begin{array}{c}-0.320^{* * * *} \\
(0.0615)\end{array}$ & $\begin{array}{c}-0.361 * * * \\
(0.0608)\end{array}$ & $\begin{array}{c}-0.284^{* * * *} \\
(0.0585)\end{array}$ \\
\hline logged total population & $\begin{array}{c}0.00450 \\
(0.00688)\end{array}$ & $\begin{array}{c}0.00530 \\
(0.00634)\end{array}$ & $\begin{array}{c}0.00436 \\
(0.00707)\end{array}$ & $\begin{array}{l}0.000265 \\
(0.00618)\end{array}$ & $\begin{array}{l}-0.00153 \\
(0.00639)\end{array}$ \\
\hline (sum) minor & $\begin{array}{c}0.00125 \\
(0.00166)\end{array}$ & & & & \\
\hline (sum) war & $\begin{array}{c}-0.00592^{* *} \\
(0.00234)\end{array}$ & & & & \\
\hline $\mathrm{bd} 1 \mathrm{k}$ & & $\begin{array}{c}-0.000396 * * * \\
(0.000149)\end{array}$ & & & \\
\hline $\operatorname{lnbd}$ & & & $\begin{array}{l}-0.00240 \\
(0.00276)\end{array}$ & & \\
\hline (sum) fsida & & & & $\begin{array}{c}-0.00340 * * * \\
(0.00120)\end{array}$ & \\
\hline$($ sum) cpia & & & & & $\begin{array}{c}0.000636 * * \\
(0.000286)\end{array}$ \\
\hline Constant & $\begin{array}{l}0.239 * * \\
(0.0935)\end{array}$ & $\begin{array}{c}0.254 * * * \\
(0.0924)\end{array}$ & $\begin{array}{c}0.257^{* * * *} \\
(0.0944)\end{array}$ & $\begin{array}{c}0.308 * * * \\
(0.0938)\end{array}$ & $\begin{array}{c}0.270^{* * *} \\
(0.0933)\end{array}$ \\
\hline $\mathrm{N}$ & 153 & 153 & 153 & 153 & 153 \\
\hline Start & 1973.6 & 1973.6 & 1973.6 & 1973.6 & 1973.6 \\
\hline End & 2008.9 & 2008.9 & 2008.9 & 2008.9 & 2008.9 \\
\hline $\mathrm{r} 2$ & 0.488 & 0.490 & 0.467 & 0.493 & 0.483 \\
\hline
\end{tabular}

Standard errors in parentheses
${ }^{*} p<0.10,{ }^{* *} p<0.05,{ }^{* *} p<0.01$ 


\section{Fixed-effects models}

Table A-13: Fixed-Effects Analysis, Primary Education Attainment, 1995-2005

\begin{tabular}{|c|c|c|c|c|c|c|}
\hline & Conflict & Battle Deaths & BD*Pop. & Fragility & CPIA & PCSE, $\operatorname{AR}(1)$ \\
\hline $1975-79$ & $\begin{array}{c}0 \\
(0)\end{array}$ & $\begin{array}{c}0 \\
(0)\end{array}$ & $\begin{array}{c}0 \\
(0)\end{array}$ & $\begin{array}{c}0 \\
(0)\end{array}$ & $\begin{array}{c}0 \\
(0)\end{array}$ & $\begin{array}{c}0 \\
(0)\end{array}$ \\
\hline $1980-84$ & 0 & 0 & 0 & 0 & 0 & 0 \\
\hline & (0) & (0) & (0) & (0) & (0) & (0) \\
\hline $1985-89$ & 0 & 0 & 0 & 0 & 0 & 0 \\
\hline & $(0)$ & $(0)$ & $(0)$ & $(0)$ & (0) & $(0)$ \\
\hline $1990-94$ & 0 & 0 & 0 & 0 & 0 & 0 \\
\hline 1995-99 & $\begin{array}{c}(0) \\
0\end{array}$ & $\begin{array}{c}(0) \\
0\end{array}$ & $\begin{array}{c}(0) \\
0\end{array}$ & $\begin{array}{c}(0) \\
-0.857\end{array}$ & $\begin{array}{c}(0) \\
-0.566\end{array}$ & $\begin{array}{c}(0) \\
77.23\end{array}$ \\
\hline & $(0)$ & $(0)$ & $(0)$ & $(1.314)$ & $(1.585)$ & \\
\hline 2000-04 & $\begin{array}{l}-0.126 \\
(1.212)\end{array}$ & $\begin{array}{l}-0.193 \\
(1.212)\end{array}$ & $\begin{array}{l}-0.131 \\
(1.219)\end{array}$ & $\begin{array}{l}-0.750 \\
(0.869)\end{array}$ & $\begin{array}{l}-0.823 \\
(1.039)\end{array}$ & 80.85 \\
\hline 2005-08 & $\begin{array}{c}0.766 \\
(1.769)\end{array}$ & $\begin{array}{c}0.632 \\
(1.773)\end{array}$ & $\begin{array}{c}0.709 \\
(1.782)\end{array}$ & $\begin{array}{c}0 \\
(0)\end{array}$ & $\begin{array}{c}0 \\
(0)\end{array}$ & 83.50 \\
\hline Log of Population & $\begin{array}{c}35.48^{* * *} \\
(7.804)\end{array}$ & $\begin{array}{c}35.31^{* * * *} \\
(7.797)\end{array}$ & $\begin{array}{c}34.91^{* * *} \\
(7.845)\end{array}$ & $\begin{array}{c}32.63^{* * *} \\
(6.325)\end{array}$ & $\begin{array}{c}42.24^{* * *} \\
(7.733)\end{array}$ & 0.636 \\
\hline Conflict_t-1 & $\begin{array}{c}0.103 \\
(0.345)\end{array}$ & & & & & $\begin{array}{c}-1.033 \\
(0)\end{array}$ \\
\hline Conflict in Neighbourhood & $\begin{array}{c}0.240 \\
(0.217)\end{array}$ & $\begin{array}{c}0.215 \\
(0.217)\end{array}$ & $\begin{array}{c}0.225 \\
(0.218)\end{array}$ & & & $\begin{array}{c}-0.743 \\
(0)\end{array}$ \\
\hline Log of Battle Deaths _t-1 & & $\begin{array}{l}-0.137 \\
(0.226)\end{array}$ & $\begin{array}{l}-0.180 \\
(0.240)\end{array}$ & & & \\
\hline Log of Battle Deaths _t-1 X Log of Population & & & $\begin{array}{l}0.0904 \\
(0.168)\end{array}$ & & & \\
\hline Fragility & & & & $\begin{array}{c}6.620^{* *} \\
(2.170)\end{array}$ & & \\
\hline Cumulative CPIA Score & & & & & $\begin{array}{l}-0.800 \\
(1.212)\end{array}$ & \\
\hline Constant & $\begin{array}{c}-234.1^{* * *} \\
(68.04)\end{array}$ & $\begin{array}{c}-232.0 * * * \\
(67.97)\end{array}$ & $\begin{array}{c}-228.7^{* * *} \\
(68.36)\end{array}$ & $\begin{array}{c}-207.6^{* * *} \\
(56.42)\end{array}$ & $\begin{array}{c}-301.1^{* * *} \\
(70.82)\end{array}$ & $\begin{array}{c}0 \\
(0)\end{array}$ \\
\hline Observations & 348 & 348 & 348 & 361 & 291 & 348 \\
\hline $\begin{array}{l}\text { Log likelihood } \\
\chi^{2}\end{array}$ & -1019.4 & -1019.1 & -1018.9 & -1049.0 & -851.5 & . \\
\hline
\end{tabular}

Table A-14: Fixed-Effects Analysis, Secondary Education Attainment 1970-2005

\begin{tabular}{|c|c|c|c|c|c|c|}
\hline & Conflict & Battle Deaths & BD*Pop. & Fragility & CPIA & PCSE, AR(1) \\
\hline \multirow[t]{2}{*}{$1975-79$} & $0.0422^{* * *}$ & $0.0423^{* * *}$ & $0.0423^{* * *}$ & $0.0444^{* * *}$ & $\begin{array}{c}0 \\
(0)\end{array}$ & $0.0511^{* * *}$ \\
\hline & $(0.00808)$ & $(0.00809)$ & $(0.00809)$ & $(0.00783)$ & (0) & $(0.00564)$ \\
\hline \multirow[t]{2}{*}{$1980-84$} & $0.0800^{* * *}$ & $0.0801^{* * *}$ & $0.0796^{* * *}$ & $0.0766^{* * *}$ & 0 & $0.0970^{* * *}$ \\
\hline & $(0.00841)$ & $(0.00843)$ & $(0.00844)$ & $(0.00825)$ & (0) & $(0.00813)$ \\
\hline \multirow[t]{2}{*}{$1985-89$} & $0.121^{* * *}$ & $0.121^{* * *}$ & $0.120^{* * *}$ & $0.115^{* * *}$ & $0.0436^{* * *}$ & $0.149^{* * *}$ \\
\hline & $(0.00929)$ & $(0.00928)$ & $(0.00930)$ & $(0.00891)$ & $(0.00739)$ & $(0.0109)$ \\
\hline \multirow[t]{2}{*}{$1990-94$} & $0.150^{* * *}$ & $0.150^{* * *}$ & $0.149^{* * *}$ & $0.143^{* * *}$ & $0.0767^{* * *}$ & $0.189^{* * *}$ \\
\hline & $(0.0103)$ & $(0.0103)$ & $(0.0103)$ & $(0.00973)$ & $(0.00905)$ & $(0.0137)$ \\
\hline \multirow[t]{2}{*}{ 1995-99 } & $0.174^{* * *}$ & $0.174^{* * *}$ & $0.173^{* * *}$ & $0.167^{* * *}$ & $0.105^{* * *}$ & $0.223^{* * *}$ \\
\hline & $(0.0112)$ & $(0.0112)$ & $(0.0112)$ & $(0.0104)$ & $(0.0112)$ & $(0.0171)$ \\
\hline \multirow{2}{*}{$2000-04$} & $0.195^{* * *}$ & $0.195^{* * *}$ & $0.194^{* * *}$ & $0.186^{* * *}$ & $0.129^{* * *}$ & $0.255^{* * *}$ \\
\hline & $(0.0121)$ & $(0.0121)$ & $(0.0121)$ & $(0.0113)$ & $(0.0130)$ & $(0.0140)$ \\
\hline \multirow[t]{2}{*}{ 2005-08 } & $0.213^{* * *}$ & $0.213^{* * *}$ & $0.212^{* * *}$ & $0.208^{* * *}$ & $0.157^{* * *}$ & $0.279^{* * *}$ \\
\hline & $(0.0128)$ & $(0.0128)$ & $(0.0129)$ & $(0.0121)$ & $(0.0146)$ & $(0.0141)$ \\
\hline Log of Population & $\begin{array}{c}0.0645^{* * *} \\
(0.0140)\end{array}$ & $\begin{array}{c}0.0641^{* * *} \\
(0.0140)\end{array}$ & $\begin{array}{c}0.0648^{* * *} \\
(0.0140)\end{array}$ & $\begin{array}{c}0.0675^{* * *} \\
(0.0131)\end{array}$ & $\begin{array}{c}0.0477 \\
(0.0245)\end{array}$ & $\begin{array}{l}-0.00498 \\
(0.00560)\end{array}$ \\
\hline \multirow[t]{2}{*}{ Conflict _t-1 } & -0.0000687 & & & & & $-0.00235^{*}$ \\
\hline & $(0.00116)$ & & & & & $(0.00112)$ \\
\hline \multirow[t]{2}{*}{ Conflict in Neighbourhood } & $-0.00250^{* *}$ & $-0.00249^{* *}$ & $-0.00245^{* *}$ & & & -0.00184 \\
\hline & $(0.000866)$ & $(0.000867)$ & $(0.000867)$ & & & $(0.00132)$ \\
\hline Log of Battle Deaths _t-1 & & $\begin{array}{l}-0.000160 \\
(0.000747)\end{array}$ & $\begin{array}{l}-0.000599 \\
(0.000831)\end{array}$ & & & \\
\hline \multicolumn{2}{|l|}{ Log of Battle Deaths _t-1 X Log of Population } & & $\begin{array}{c}0.000608 \\
(0.000506)\end{array}$ & & & \\
\hline Fragility & & & & $\begin{array}{l}0.000516 \\
(0.00684)\end{array}$ & & \\
\hline Cumulative CPIA Score & & & & & $\begin{array}{l}-0.00121 \\
(0.00326)\end{array}$ & \\
\hline Constant & $\begin{array}{l}-0.168 \\
(0.118)\end{array}$ & $\begin{array}{l}-0.165 \\
(0.119)\end{array}$ & $\begin{array}{l}-0.170 \\
(0.119)\end{array}$ & $\begin{array}{l}-0.194 \\
(0.110)\end{array}$ & $\begin{array}{c}0.00257 \\
(0.212) \\
\end{array}$ & $\begin{array}{c}0.425^{* * *} \\
(0.0546)\end{array}$ \\
\hline Observations & 1035 & 1035 & 1035 & 1081 & 652 & 1035 \\
\hline Log likelihood & 1561.4 & 1561.4 & 1562.3 & 1624.1 & 1162.1 & \\
\hline$\chi^{2}$ & & & & & & 821.4 \\
\hline
\end{tabular}

Standard errors in parentheses

${ }^{*} p<0.05,{ }^{* *} p<0.01,{ }^{* * *} p<0.001$ 


\section{A.3.3 MDG 3: Gender Parity}

\section{Cross-sectional analyses}

Table A-15: Improvement in female-to-male primary school attainment ratio, cross-section 19752006

\begin{tabular}{|c|c|c|c|c|c|}
\hline & $\begin{array}{c}(1) \\
\text { improvement }\end{array}$ & $\begin{array}{c}(2) \\
\text { improvement }\end{array}$ & $\begin{array}{c}(3) \\
\text { improvement }\end{array}$ & $\begin{array}{c}(4) \\
\text { improvement }\end{array}$ & $\begin{array}{c}(5) \\
\text { improvement }\end{array}$ \\
\hline exposure & $0.246^{* * *}$ & $0.257^{* * *}$ & $0.260^{* * *}$ & $0.235^{* * *}$ & $0.192^{* *}$ \\
\hline (firstnm) femedu & $\begin{array}{c}-0.826 * * * \\
(0.0338)\end{array}$ & $\begin{array}{c}-0.846^{* * *} \\
(0.0329)\end{array}$ & $\begin{array}{c}-0.834^{* * *} \\
(0.0347)\end{array}$ & $\begin{array}{c}(0.0804) \\
-0.873^{* * *} \\
(0.0349)\end{array}$ & $\begin{array}{c}-0.825^{* * *} \\
(0.0341)\end{array}$ \\
\hline logged total population & $\begin{array}{c}-0.0180 \\
(0.403)\end{array}$ & $\begin{array}{c}0.122 \\
(0.356)\end{array}$ & $\begin{array}{c}0.146 \\
(0.410)\end{array}$ & $\begin{array}{l}-0.320 \\
(0.350)\end{array}$ & $\begin{array}{l}-0.357 \\
(0.382)\end{array}$ \\
\hline $\begin{array}{l}(\text { sum }) \text { minor } \\
(\text { sum }) \text { war }\end{array}$ & $\begin{array}{c}0.0768 \\
(0.109) \\
-0.369 * * \\
(0.156)\end{array}$ & & & & \\
\hline $\mathrm{bd} 1 \mathrm{k}$ & & $\begin{array}{c}-0.0384 * * * \\
(0.00935)\end{array}$ & & & \\
\hline $\operatorname{lnbd}$ & & & $\begin{array}{r}-0.293^{*} \\
(0.164)\end{array}$ & & \\
\hline (sum) fsida & & & & $\begin{array}{c}-0.336 * * * \\
(0.0838)\end{array}$ & \\
\hline$($ sum) cpia & & & & & $\begin{array}{c}0.0271 \\
(0.0184)\end{array}$ \\
\hline Constant & $\begin{array}{c}76.72^{* * *} \\
(5.166)\end{array}$ & $\begin{array}{c}77.55^{* * *} \\
(4.895)\end{array}$ & $\begin{array}{c}77.06^{* * *} \\
(5.135)\end{array}$ & $\begin{array}{c}83.08^{* * * *} \\
(5.088)\end{array}$ & $\begin{array}{c}80.03^{* * * *} \\
(5.384)\end{array}$ \\
\hline $\mathrm{N}$ & 151 & 151 & 151 & 151 & 151 \\
\hline Start & 1975.7 & 1975.7 & 1975.7 & 1975.7 & 1975.7 \\
\hline End & 2006.3 & 2006.3 & 2006.3 & 2006.3 & 2006.3 \\
\hline r2 & 0.889 & 0.897 & 0.887 & 0.896 & 0.886 \\
\hline
\end{tabular}

Standard errors in parentheses

* $p<0.10,{ }^{* *} p<0.05, * * * p<0.01$

Table A-16: Improvement in female-to-male life expectancy ratio, cross-section 1967-2007

\begin{tabular}{|c|c|c|c|c|c|}
\hline & $\begin{array}{c}\text { (1) } \\
\text { improvement }\end{array}$ & $\begin{array}{c}(2) \\
\text { improvement }\end{array}$ & $\begin{array}{c}\text { (3) } \\
\text { improvement }\end{array}$ & $\begin{array}{c}\text { (4) } \\
\text { improvement }\end{array}$ & $\begin{array}{c}\text { (5) } \\
\text { improvement }\end{array}$ \\
\hline exposure & $\begin{array}{l}-0.0146 \\
(0.0287)\end{array}$ & $\begin{array}{l}-0.0115 \\
(0.0288)\end{array}$ & $\begin{array}{c}-0.00935 \\
(0.0289)\end{array}$ & $\begin{array}{c}-0.00772 \\
(0.0286)\end{array}$ & $\begin{array}{l}-0.0134 \\
(0.0292)\end{array}$ \\
\hline (firstnm) ratio & $\begin{array}{c}-0.749^{* * *} \\
(0.0686)\end{array}$ & $\begin{array}{c}-0.746^{* * *} * \\
(0.0688)\end{array}$ & $\begin{array}{c}-0.742^{* * *} * \\
(0.0690)\end{array}$ & $\begin{array}{c}-0.731^{* * *} \\
(0.0688)\end{array}$ & $\begin{array}{c}-0.745^{* * *} \\
(0.0688)\end{array}$ \\
\hline logged total population & $\begin{array}{c}0.191 \\
(0.164)\end{array}$ & $\begin{array}{l}0.293^{*} \\
(0.155)\end{array}$ & $\begin{array}{c}0.342^{* *} \\
(0.169)\end{array}$ & $\begin{array}{l}0.288^{*} \\
(0.149)\end{array}$ & $\begin{array}{l}0.286^{*} \\
(0.153)\end{array}$ \\
\hline $\begin{array}{l}\text { (sum) minor } \\
\text { (sum) war }\end{array}$ & $\begin{array}{c}0.0319 \\
(0.0322) \\
0.0454 \\
(0.0465)\end{array}$ & & & & \\
\hline $\mathrm{bd} 1 \mathrm{k}$ & & $\begin{array}{l}0.000533 \\
(0.00315)\end{array}$ & & & \\
\hline $\operatorname{lnbd}$ & & & $\begin{array}{c}-0.0338 \\
(0.0596)\end{array}$ & & \\
\hline (sum) fsida & & & & $\begin{array}{l}-0.0420 \\
(0.0265)\end{array}$ & \\
\hline (sum) cpia & & & & & $\begin{array}{c}0.00281 \\
(0.00641)\end{array}$ \\
\hline Constant & $\begin{array}{c}78.22^{* * *} \\
(7.636)\end{array}$ & $\begin{array}{c}77.26^{* * *} \\
(7.652)\end{array}$ & $\begin{array}{c}76.59^{* * *} \\
(7.702)\end{array}$ & $\begin{array}{c}75.68^{* * * *} \\
(7.631)\end{array}$ & $\begin{array}{c}77.16^{* * *} \\
(7.634)\end{array}$ \\
\hline $\mathrm{N}$ & 153 & 153 & 153 & 153 & 153 \\
\hline Start & 1967.6 & 1967.6 & 1967.6 & 1967.6 & 1967.6 \\
\hline End & 2007.2 & 2007.2 & 2007.2 & 2007.2 & 2007.2 \\
\hline $\mathrm{r} 2$ & 0.600 & 0.593 & 0.593 & 0.600 & 0.593 \\
\hline
\end{tabular}

Standard errors in parentheses

${ }^{*} p<0.10,{ }^{* *} p<0.05,{ }^{* * *} p<0.01$ 


\section{Fixed-effects models}

Table A-17: Fixed-Effects Analysis, Female-to-Male Primary School Attainment Ratio 1975-2006

\begin{tabular}{|c|c|c|c|c|c|c|}
\hline & Conflict & Battle Deaths & BD*Pop. & Fragility & CPIA & PCSE, $\operatorname{AR}(1)$ \\
\hline $1975-79$ & $\begin{array}{l}-0.210 \\
(1.569)\end{array}$ & $\begin{array}{l}-0.0572 \\
(1.574)\end{array}$ & $\begin{array}{c}-0.0462 \\
(1.574)\end{array}$ & $\begin{array}{l}-1.285 \\
(1.511)\end{array}$ & $\begin{array}{c}0 \\
(0)\end{array}$ & $\begin{array}{c}2.125 \\
(1.287)\end{array}$ \\
\hline $1980-84$ & $\begin{array}{c}0.0263 \\
(1.632)\end{array}$ & $\begin{array}{c}0.304 \\
(1.634)\end{array}$ & 0.251 & 0.381 & 1.637 & $6.171^{* * *}$ \\
\hline $1985-89$ & $\begin{array}{c}(1.632) \\
-0.944 \\
(1.763)\end{array}$ & $\begin{array}{c}(1.634) \\
-0.512 \\
(1.761)\end{array}$ & $\begin{array}{c}(1.634) \\
-0.581 \\
(1.761)\end{array}$ & $\begin{array}{c}(1.574) \\
0.419 \\
(1.682)\end{array}$ & $\begin{array}{c}(1.177) \\
0.429 \\
(0.940)\end{array}$ & $\begin{array}{c}(1.451) \\
8.720^{* * *} \\
(1.583)\end{array}$ \\
\hline $1990-94$ & $\begin{array}{l}-1.314 \\
(1.907)\end{array}$ & $\begin{array}{l}-0.785 \\
(1.902)\end{array}$ & $\begin{array}{l}-0.837 \\
(1.902)\end{array}$ & $\begin{array}{c}0.566 \\
(1.809)\end{array}$ & $\begin{array}{l}0 \\
(0)\end{array}$ & $\begin{array}{c}11.16^{* * *} \\
(1.675)\end{array}$ \\
\hline 1995-99 & $\begin{array}{l}-2.386 \\
(2.051)\end{array}$ & $\begin{array}{l}-1.805 \\
(2.045)\end{array}$ & $\begin{array}{l}-1.862 \\
(2.044)\end{array}$ & $\begin{array}{l}0.0975 \\
(1.941)\end{array}$ & $\begin{array}{l}-1.604 \\
(0.911)\end{array}$ & $\begin{array}{c}12.51^{* * *} \\
(1.737)\end{array}$ \\
\hline 2000-04 & $\begin{array}{l}-2.615 \\
(2.205)\end{array}$ & $\begin{array}{l}-2.008 \\
(2.199)\end{array}$ & $\begin{array}{l}-2.089 \\
(2.199)\end{array}$ & $\begin{array}{l}-0.311 \\
(2.075)\end{array}$ & $\begin{array}{l}-2.004 \\
(1.078)\end{array}$ & $\begin{array}{c}14.21^{* * *} \\
(1.731)\end{array}$ \\
\hline 2005-08 & $\begin{array}{l}-1.215 \\
(2.331)\end{array}$ & $\begin{array}{l}-0.574 \\
(2.325)\end{array}$ & $\begin{array}{l}-0.706 \\
(2.326)\end{array}$ & $\begin{array}{c}0.513 \\
(2.202)\end{array}$ & $\begin{array}{l}-1.680 \\
(1.242)\end{array}$ & $\begin{array}{c}16.57^{* * *} \\
(1.753)\end{array}$ \\
\hline Log of Population & $\begin{array}{c}21.56^{* * * *} \\
(2.295)\end{array}$ & $\begin{array}{c}21.07^{* * * *} \\
(2.296)\end{array}$ & $\begin{array}{c}21.08^{* * *} \\
(2.294)\end{array}$ & $\begin{array}{c}18.51^{* * *} \\
(2.158)\end{array}$ & $\begin{array}{c}25.53^{* * *} * \\
(3.220)\end{array}$ & $\begin{array}{r}-0.855^{*} \\
(0.407)\end{array}$ \\
\hline Conflict_t-1 & $\begin{array}{c}0.406^{* *} \\
(0.148)\end{array}$ & & & & & $\begin{array}{l}-0.186 \\
(0.193)\end{array}$ \\
\hline Conflict in Neighbourhood & $\begin{array}{c}0.553^{* * *} \\
(0.116)\end{array}$ & $\begin{array}{c}0.566^{* * *} \\
(0.116)\end{array}$ & $\begin{array}{c}0.569^{* * *} \\
(0.116)\end{array}$ & & & $\begin{array}{c}-0.00739 \\
(0.160)\end{array}$ \\
\hline Log of Battle Deaths _t-1 & & $\begin{array}{c}0.121 \\
(0.0972)\end{array}$ & $\begin{array}{l}0.0554 \\
(0.108)\end{array}$ & & & \\
\hline Log of Battle Deaths _t-1 X Log of Population & & & $\begin{array}{c}0.0903 \\
(0.0655)\end{array}$ & & & \\
\hline Fragility & & & & $\begin{array}{c}1.243 \\
(0.941)\end{array}$ & & \\
\hline Cumulative CPIA Score & & & & & $\begin{array}{l}-0.756 \\
(0.424)\end{array}$ & \\
\hline Constant & $\begin{array}{c}-103.1^{* * *} \\
(19.13)\end{array}$ & $\begin{array}{c}-99.13^{* * *} \\
(19.14)\end{array}$ & $\begin{array}{c}-99.18^{* * *} \\
(19.12)\end{array}$ & $\begin{array}{c}-73.64^{* * *} \\
(17.91)\end{array}$ & $\begin{array}{c}-137.2^{* * *} \\
(28.71)\end{array}$ & $\begin{array}{c}85.97^{* * * *} \\
(3.511)\end{array}$ \\
\hline Observations & 907 & 907 & 907 & 939 & 631 & 907 \\
\hline $\begin{array}{l}\text { Log likelihood } \\
\chi^{2}\end{array}$ & -2969.1 & -2972.7 & -2971.5 & -3101.3 & -1938.5 & 1237.3 \\
\hline
\end{tabular}

${ }^{*} p<0.05,{ }^{* *} p<0.01,{ }^{* * *} p<0.001$

Table A-18: Fixed-Effects Analysis, Female-to-Male Life Expectancy Ratio 1967-2007

\begin{tabular}{|c|c|c|c|c|c|c|}
\hline & Conflict & Battle Deaths & BD*Pop. & Fragility & CPIA & PCSE, $\operatorname{AR}(1)$ \\
\hline $1975-79$ & $\begin{array}{c}0.629^{* *} \\
(0.205)\end{array}$ & $\begin{array}{c}0.621^{* *} \\
(0.206)\end{array}$ & $\begin{array}{c}0.620^{* *} \\
(0.205)\end{array}$ & $\begin{array}{l}0.498^{*} \\
(0.202)\end{array}$ & $\begin{array}{c}0 \\
(0)\end{array}$ & $\begin{array}{l}0.350^{*} \\
(0.138)\end{array}$ \\
\hline $1980-84$ & $\begin{array}{c}1.134^{* * *} \\
(0.216)\end{array}$ & $\begin{array}{c}1.133^{* * * *} \\
(0.216)\end{array}$ & $\begin{array}{c}1.104^{* * *} \\
(0.216)\end{array}$ & $\begin{array}{c}1.104^{* * *} \\
(0.213)\end{array}$ & $\begin{array}{c}-0.634^{*} \\
(0.252)\end{array}$ & $\begin{array}{c}0.758^{* * *} \\
(0.210)\end{array}$ \\
\hline $1985-89$ & $\begin{array}{c}1.548^{* * *} \\
(0.241)\end{array}$ & $\begin{array}{c}1.558^{* * *} \\
(0.240)\end{array}$ & $\begin{array}{c}1.514^{* * *} \\
(0.240)\end{array}$ & $\begin{array}{c}1.542^{* * *} \\
(0.232)\end{array}$ & $\begin{array}{c}-0.406^{*} \\
(0.202)\end{array}$ & $\begin{array}{c}1.039^{* * *} \\
(0.268)\end{array}$ \\
\hline $1990-94$ & $\begin{array}{c}1.995^{* * *} \\
(0.269)\end{array}$ & $\begin{array}{c}2.009^{* * *} \\
(0.268)\end{array}$ & $\begin{array}{c}1.964^{* * *} \\
(0.268)\end{array}$ & $\begin{array}{c}2.050^{* * *} \\
(0.255)\end{array}$ & $\begin{array}{c}0 \\
(0)\end{array}$ & $\begin{array}{c}1.366^{* * *} \\
(0.322)\end{array}$ \\
\hline 1995-99 & $\begin{array}{c}2.340^{* * * *} \\
(0.297)\end{array}$ & $\begin{array}{c}2.353^{* * *} \\
(0.296)\end{array}$ & $\begin{array}{c}2.302^{* * *} \\
(0.296)\end{array}$ & $\begin{array}{c}2.483^{* * *} \\
(0.279)\end{array}$ & $\begin{array}{c}0.325 \\
(0.196)\end{array}$ & $\begin{array}{c}1.627^{* * *} \\
(0.380)\end{array}$ \\
\hline $2000-04$ & $\begin{array}{c}2.107^{* * *} \\
(0.323)\end{array}$ & $\begin{array}{c}2.119^{* * *} \\
(0.323)\end{array}$ & $\begin{array}{c}2.056^{* * *} \\
(0.323)\end{array}$ & $\begin{array}{c}2.117^{* * *} \\
(0.302)\end{array}$ & $\begin{array}{l}-0.119 \\
(0.229)\end{array}$ & $\begin{array}{c}1.277^{* * *} \\
(0.296)\end{array}$ \\
\hline 2005-08 & $\begin{array}{c}1.936^{* * *} \\
(0.344)\end{array}$ & $\begin{array}{c}1.951^{* * *} \\
(0.344)\end{array}$ & $\begin{array}{c}1.869^{* * *} \\
(0.345)\end{array}$ & $\begin{array}{c}1.861^{* * *} \\
(0.325)\end{array}$ & $\begin{array}{l}-0.475 \\
(0.263)\end{array}$ & $\begin{array}{c}0.848^{* *} \\
(0.289)\end{array}$ \\
\hline Log of Population & $\begin{array}{c}-2.016^{* * *} \\
(0.381)\end{array}$ & $\begin{array}{c}-2.020^{* * *} \\
(0.381)\end{array}$ & $\begin{array}{c}-1.976^{* * *} \\
(0.381)\end{array}$ & $\begin{array}{c}-2.047^{* * *} \\
(0.359)\end{array}$ & $\begin{array}{l}-1.121 \\
(0.681)\end{array}$ & $\begin{array}{r}-0.0387 \\
(0.109)\end{array}$ \\
\hline Conflict _t-1 & $\begin{array}{c}0.0404 \\
(0.0291)\end{array}$ & & & & & $\begin{array}{c}0.0155 \\
(0.0371)\end{array}$ \\
\hline Conflict in Neighbourhood & $\begin{array}{c}0.0609^{* *} \\
(0.0218)\end{array}$ & $\begin{array}{c}0.0610^{* *} \\
(0.0219)\end{array}$ & $\begin{array}{c}0.0627^{* *} \\
(0.0218)\end{array}$ & & & $\begin{array}{l}-0.00344 \\
(0.0230)\end{array}$ \\
\hline Log of Battle Deaths _t-1 & & $\begin{array}{c}0.0233 \\
(0.0188)\end{array}$ & $\begin{array}{l}0.00176 \\
(0.0209)\end{array}$ & & & \\
\hline Log of Battle Deaths _t-1 X Log of Population & & & $\begin{array}{l}0.0298^{*} \\
(0.0127)\end{array}$ & & & \\
\hline Fragility & & & & $\begin{array}{l}0.0904 \\
(0.176)\end{array}$ & & \\
\hline Cumulative CPIA Score & & & & & $\begin{array}{c}-0.141 \\
(0.0908)\end{array}$ & \\
\hline Constant & $\begin{array}{c}122.9^{* * *} \\
(3.205)\end{array}$ & $\begin{array}{c}122.9^{* * *} \\
(3.210)\end{array}$ & $\begin{array}{c}122.6^{* * * *} \\
(3.205)\end{array}$ & $\begin{array}{c}123.6^{* * *} \\
(3.002)\end{array}$ & $\begin{array}{c}118.2^{* * *} \\
(6.055)\end{array}$ & $\begin{array}{c}106.8^{* * *} \\
(1.125)\end{array}$ \\
\hline Observations & 1029 & 1029 & 1029 & 1068 & 651 & 1029 \\
\hline $\begin{array}{l}\text { Log likelihood } \\
\chi^{2}\end{array}$ & -1764.3 & -1764.6 & -1761.3 & -1846.6 & -1005.3 & 25.59 \\
\hline
\end{tabular}

Standard errors in parentheses

${ }^{*} p<0.05,{ }^{* *} p<0.01,{ }^{* * *} p<0.001$ 


\section{A.3.4 MDG 4: Child Mortality}

\section{Cross-sectional analyses}

Table A-19: Improvement in log infant mortality rates, Cross-section 1969-2005

\begin{tabular}{|c|c|c|c|c|c|}
\hline & $\begin{array}{c}(1) \\
\text { improvement }\end{array}$ & $\begin{array}{c}(2) \\
\text { improvement }\end{array}$ & $\begin{array}{c}(3) \\
\text { improvement }\end{array}$ & $\begin{array}{c}(4) \\
\text { improvement }\end{array}$ & $\begin{array}{c}(5) \\
\text { improvement }\end{array}$ \\
\hline exposure & $\begin{array}{c}-0.0343^{* * *} \\
(0.00431)\end{array}$ & $\begin{array}{c}-0.0345^{* * *} \\
(0.00417)\end{array}$ & $\begin{array}{c}-0.0345^{* * *} \\
(0.00428)\end{array}$ & $\begin{array}{c}-0.0307^{* * *} \\
(0.00416)\end{array}$ & $\begin{array}{c}-0.0322^{* * *} \\
(0.00443)\end{array}$ \\
\hline (firstnm) limr & $\begin{array}{c}-0.0510 \\
(0.0709)\end{array}$ & $\begin{array}{l}-0.0525 \\
(0.0686)\end{array}$ & $\begin{array}{l}-0.0733 \\
(0.0713)\end{array}$ & $\begin{array}{c}-0.154^{* *} \\
(0.0722)\end{array}$ & $\begin{array}{l}-0.0179 \\
(0.0731)\end{array}$ \\
\hline logged total population & $\begin{array}{c}0.0321 \\
(0.0275)\end{array}$ & $\begin{array}{c}0.0272 \\
(0.0251)\end{array}$ & $\begin{array}{c}0.0165 \\
(0.0277)\end{array}$ & $\begin{array}{l}0.0597^{* *} \\
(0.0242)\end{array}$ & $\begin{array}{l}0.0543 * * \\
(0.0257)\end{array}$ \\
\hline $\begin{array}{l}\text { (sum) minor } \\
(\text { sum) war }\end{array}$ & $\begin{array}{c}0.000496 \\
(0.00534) \\
0.0195^{* *} \\
(0.00768)\end{array}$ & & & & \\
\hline bd $1 \mathrm{k}$ & & $\begin{array}{c}0.00208^{* * *} \\
(0.000528)\end{array}$ & & & \\
\hline $\operatorname{lnbd}$ & & & $\begin{array}{c}0.0277^{* * *} * \\
(0.00993)\end{array}$ & & \\
\hline (sum) fsida & & & & $\begin{array}{c}0.0202 * * * \\
(0.00454)\end{array}$ & \\
\hline (sum) cpia & & & & & $\begin{array}{l}-0.00164 \\
(0.00107)\end{array}$ \\
\hline Constant & $\begin{array}{l}-0.238 \\
(0.315)\end{array}$ & $\begin{array}{l}-0.219 \\
(0.302)\end{array}$ & $\begin{array}{l}-0.136 \\
(0.321)\end{array}$ & $\begin{array}{l}-0.137 \\
(0.300)\end{array}$ & $\begin{array}{c}-0.536^{*} \\
(0.321)\end{array}$ \\
\hline $\mathrm{N}$ & 153 & 153 & 153 & 153 & 153 \\
\hline Start & 1969.9 & 1969.9 & 1969.9 & 1969.9 & 1969.9 \\
\hline End & 2006.9 & 2006.9 & 2006.9 & 2006.9 & 2006.9 \\
\hline r2 & 0.652 & 0.671 & 0.654 & 0.680 & 0.641 \\
\hline
\end{tabular}

Standard errors in parentheses

* $p<0.10,{ }^{* *} p<0.05, * * * \quad p<0.01$

Table A-20: Improvement in under-five mortality rate, Cross-section 1991-2003

\begin{tabular}{|c|c|c|c|c|c|}
\hline & $\begin{array}{c}(1) \\
\text { improvement }\end{array}$ & $\begin{array}{c}(2) \\
\text { improvement }\end{array}$ & $\begin{array}{c}(3) \\
\text { improvement }\end{array}$ & $\begin{array}{c}(4) \\
\text { improvement }\end{array}$ & $\begin{array}{c}(5) \\
\text { improvement }\end{array}$ \\
\hline exposure & $\begin{array}{c}-0.948^{* * *} \\
(0.279)\end{array}$ & $\begin{array}{c}-0.974^{* * *} \\
(0.261)\end{array}$ & $\begin{array}{c}-0.935^{* * *} \\
(0.279)\end{array}$ & $\begin{array}{c}-0.674^{* * *} \\
(0.255)\end{array}$ & $\begin{array}{c}-0.629^{* *} \\
(0.280)\end{array}$ \\
\hline (firstnm) underfivemort & $\begin{array}{c}-0.683^{* * *} \\
(0.0360)\end{array}$ & $\begin{array}{c}-0.689^{* * *} * \\
(0.0337)\end{array}$ & $\begin{array}{c}-0.699^{* * *} \\
(0.0369)\end{array}$ & $\begin{array}{c}-0.752^{* * *} \\
(0.0348)\end{array}$ & $\begin{array}{c}-0.663 * * * \\
(0.0352)\end{array}$ \\
\hline logged total population & $\begin{array}{l}-0.733 \\
(1.826)\end{array}$ & $\begin{array}{l}-1.627 \\
(1.592)\end{array}$ & $\begin{array}{l}-1.939 \\
(1.845)\end{array}$ & $\begin{array}{c}1.005 \\
(1.509)\end{array}$ & $\begin{array}{c}1.238 \\
(1.636)\end{array}$ \\
\hline $\begin{array}{l}(\text { sum }) \text { minor } \\
(\text { sum) war }\end{array}$ & $\begin{array}{c}-0.0866 \\
(0.376) \\
1.458^{* * *} \\
(0.514)\end{array}$ & & & & \\
\hline bd1k & & $\begin{array}{c}0.185^{* * * *} \\
(0.0345)\end{array}$ & & & \\
\hline $\operatorname{lnbd}$ & & & $\begin{array}{c}1.874^{* * * *} \\
(0.679)\end{array}$ & & \\
\hline (sum) fsida & & & & $\begin{array}{c}1.808^{* * * *} \\
(0.288)\end{array}$ & \\
\hline (sum) cpia & & & & & $\begin{array}{c}-0.260^{* * *} \\
(0.0677)\end{array}$ \\
\hline Constant & $\begin{array}{c}18.54 \\
(15.63) \\
\end{array}$ & $\begin{array}{c}23.15 \\
(14.29) \\
\end{array}$ & $\begin{array}{c}20.87 \\
(15.62)\end{array}$ & $\begin{array}{c}4.084 \\
(13.65)\end{array}$ & $\begin{array}{l}-0.0447 \\
(14.83)\end{array}$ \\
\hline $\mathrm{N}$ & 153 & 153 & 153 & 153 & 153 \\
\hline Start & 1970.2 & 1970.2 & 1970.2 & 1970.2 & 1970.2 \\
\hline End & 2006.9 & 2006.9 & 2006.9 & 2006.9 & 2006.9 \\
\hline $\mathrm{r} 2$ & 0.846 & 0.864 & 0.845 & 0.872 & 0.852 \\
\hline
\end{tabular}

${ }^{*} p<0.10,{ }^{* *} p<0.05,{ }^{* * *} p<0.01$ 


\section{Fixed-effects models}

Table A-21: Fixed-Effects Analysis, Log Infant Mortality Rates 1970-2005

\begin{tabular}{|c|c|c|c|c|c|c|}
\hline & Conflict & Battle Deaths & BD*Pop. & Fragility & CPIA & PCSE, $\operatorname{AR}(1)$ \\
\hline $1975-79$ & $\begin{array}{c}-0.197^{* * *} \\
(0.0318)\end{array}$ & $\begin{array}{c}-0.205^{* * *} \\
(0.0316)\end{array}$ & $\begin{array}{c}-0.206^{* * *} \\
(0.0315)\end{array}$ & $\begin{array}{c}-0.212^{* * *} \\
(0.0311)\end{array}$ & $\begin{array}{c}0 \\
(0)\end{array}$ & $\begin{array}{c}-0.160^{* * *} \\
(0.00703)\end{array}$ \\
\hline $1980-84$ & $\begin{array}{c}-0.430 * * * \\
(0.0330)\end{array}$ & $\begin{array}{c}-0.436^{* * *} \\
(0.0328)\end{array}$ & $\begin{array}{c}-0.431 * * * \\
(0.0328)\end{array}$ & $\begin{array}{c}-0.433^{* * *} \\
(0.0325)\end{array}$ & $\begin{array}{c}0 \\
(0)\end{array}$ & $\begin{array}{c}-0.351^{* * *} \\
(0.0124)\end{array}$ \\
\hline $1985-89$ & $\begin{array}{c}-0.651^{* * *} \\
(0.0369)\end{array}$ & $\begin{array}{c}-0.656^{* * *} \\
(0.0366)\end{array}$ & $\begin{array}{c}-0.649^{* * *} \\
(0.0366)\end{array}$ & $\begin{array}{c}-0.635^{* * *} \\
(0.0356)\end{array}$ & $\begin{array}{c}-0.249^{* * *} \\
(0.0265)\end{array}$ & $\begin{array}{c}-0.536^{* * *} \\
(0.0216)\end{array}$ \\
\hline $1990-94$ & $\begin{array}{c}-0.835^{* * *} \\
(0.0410)\end{array}$ & $\begin{array}{c}-0.841^{* * *} \\
(0.0405)\end{array}$ & $\begin{array}{c}-0.834^{* * *} \\
(0.0405)\end{array}$ & $\begin{array}{c}-0.809^{* * *} * \\
(0.0388)\end{array}$ & $\begin{array}{c}-0.458^{* * *} \\
(0.0322)\end{array}$ & $\begin{array}{c}-0.689^{* * *} \\
(0.0265)\end{array}$ \\
\hline $1995-99$ & $\begin{array}{c}-1.005^{* * *} \\
(0.0452)\end{array}$ & $\begin{array}{c}-1.014^{* * *} \\
(0.0447)\end{array}$ & $\begin{array}{c}-1.005^{* * *} \\
(0.0448)\end{array}$ & $\begin{array}{c}-0.951^{* * *} \\
(0.0424)\end{array}$ & $\begin{array}{c}-0.629^{* * *} \\
(0.0398)\end{array}$ & $\begin{array}{c}-0.832^{* * *} \\
(0.0318)\end{array}$ \\
\hline 2000-04 & $\begin{array}{c}-1.172^{* * *} \\
(0.0492)\end{array}$ & $\begin{array}{c}-1.182^{* * *} \\
(0.0487)\end{array}$ & $\begin{array}{c}-1.172^{* * *} \\
(0.0488)\end{array}$ & $\begin{array}{c}-1.132^{* * *} \\
(0.0459)\end{array}$ & $\begin{array}{c}-0.840^{* * *} \\
(0.0462)\end{array}$ & $\begin{array}{c}-0.975^{* * *} \\
(0.0277)\end{array}$ \\
\hline 2005-08 & $\begin{array}{c}-1.352^{* * *} \\
(0.0524)\end{array}$ & $\begin{array}{c}-1.359^{* * *} \\
(0.0519)\end{array}$ & $\begin{array}{c}-1.346^{* * *} \\
(0.0521)\end{array}$ & $\begin{array}{c}-1.315^{* * *} \\
(0.0493)\end{array}$ & $\begin{array}{c}-1.048^{* * *} \\
(0.0520)\end{array}$ & $\begin{array}{c}-1.130^{* * *} \\
(0.0293)\end{array}$ \\
\hline Log of Population & $\begin{array}{c}0.369^{* * *} \\
(0.0582)\end{array}$ & $\begin{array}{c}0.384^{* * *} \\
(0.0578)\end{array}$ & $\begin{array}{c}0.376^{* * *} \\
(0.0577)\end{array}$ & $\begin{array}{c}0.289^{* * *} \\
(0.0544)\end{array}$ & $\begin{array}{c}0.725^{* * *} \\
(0.0875)\end{array}$ & $\begin{array}{c}0.0767^{* * *} \\
(0.0200)\end{array}$ \\
\hline Conflict_t-1 & $\begin{array}{c}0.0111^{*} \\
(0.00441)\end{array}$ & & & & & $\begin{array}{c}0.00863^{* *} \\
(0.00277)\end{array}$ \\
\hline Conflict in Neighbourhood & $\begin{array}{c}0.00511 \\
(0.00334)\end{array}$ & $\begin{array}{c}0.00455 \\
(0.00331)\end{array}$ & $\begin{array}{c}0.00424 \\
(0.00330)\end{array}$ & & & $\begin{array}{c}0.00534 \\
(0.00311)\end{array}$ \\
\hline Log of Battle Deaths _t-1 & & $\begin{array}{c}0.0131^{* * *} \\
(0.00284)\end{array}$ & $\begin{array}{c}0.0163^{* * *} \\
(0.00321)\end{array}$ & & & \\
\hline Log of Battle Deaths _t-1 X Log of Population & & & $\begin{array}{r}-0.00427^{*} \\
(0.00195)\end{array}$ & & & \\
\hline Fragility & & & & $\begin{array}{c}0.0997^{* * *} \\
(0.0270)\end{array}$ & & \\
\hline Cumulative CPIA Score & & & & & $\begin{array}{l}-0.0121 \\
(0.0116)\end{array}$ & \\
\hline Constant & $\begin{array}{c}1.314^{* *} \\
(0.492)\end{array}$ & $\begin{array}{l}1.174^{*} \\
(0.488)\end{array}$ & $\begin{array}{l}1.239^{*} \\
(0.488)\end{array}$ & $\begin{array}{c}2.024^{* * *} \\
(0.457)\end{array}$ & $\begin{array}{r}-1.959^{*} \\
(0.759)\end{array}$ & $\begin{array}{c}3.711^{* * *} \\
(0.194)\end{array}$ \\
\hline Observations & 1006 & 1006 & 1006 & 1043 & 642 & 1006 \\
\hline $\begin{array}{l}\text { Log likelihood } \\
\chi^{2}\end{array}$ & 181.8 & 190.5 & 193.3 & 186.1 & 340.0 & 4304.6 \\
\hline
\end{tabular}

${ }^{*} p<0.05,{ }^{* *} p<0.01,{ }^{* * *} p<0.001$

Table A-22: Fixed-Effects Analysis, Under-Five Year Mortality Rates 1970-2005

\begin{tabular}{|c|c|c|c|c|c|c|}
\hline & Conflict & Battle Deaths & BD*Pop. & Fragility & CPIA & PCSE, $\operatorname{AR}(1)$ \\
\hline $1975-79$ & $\begin{array}{c}-14.37^{* * *} \\
(2.724)\end{array}$ & $\begin{array}{c}-14.10^{* * *} \\
(2.723)\end{array}$ & $\begin{array}{c}-14.12^{* * *} \\
(2.711)\end{array}$ & $\begin{array}{c}-16.26^{* * *} \\
(2.657)\end{array}$ & $\begin{array}{c}0 \\
(0)\end{array}$ & $\begin{array}{c}-20.09^{* * *} \\
(0.652)\end{array}$ \\
\hline $1980-84$ & $\begin{array}{c}-26.68^{* * * *} \\
(2.844)\end{array}$ & $\begin{array}{c}-26.43^{* * *} \\
(2.841)\end{array}$ & $\begin{array}{c}-25.84^{* * *} \\
(2.835)\end{array}$ & $\begin{array}{c}-29.07^{* * *} \\
(2.793)\end{array}$ & $\begin{array}{c}19.07^{* * *} \\
(3.014)\end{array}$ & $\begin{array}{c}-40.28^{* * *} \\
(0.974)\end{array}$ \\
\hline $1985-89$ & $\begin{array}{c}-34.60^{* * * *} \\
(3.162)\end{array}$ & $\begin{array}{c}-34.32^{* * *} \\
(3.149)\end{array}$ & $\begin{array}{c}-33.56^{* * *} \\
(3.145)\end{array}$ & $\begin{array}{c}-38.00^{* * *} \\
(3.036)\end{array}$ & $\begin{array}{c}6.763^{* *} \\
(2.397)\end{array}$ & $\begin{array}{c}-56.00^{* * *} \\
(1.579)\end{array}$ \\
\hline $1990-94$ & $\begin{array}{c}-38.63^{* * *} * \\
(3.520)\end{array}$ & $\begin{array}{c}-38.35^{* * *} \\
(3.502)\end{array}$ & $\begin{array}{c}-37.55^{* * *} \\
(3.496)\end{array}$ & $\begin{array}{c}-42.80^{* * *} \\
(3.331)\end{array}$ & $\begin{array}{c}0 \\
(0)\end{array}$ & $\begin{array}{c}-67.12^{* * *} \\
(2.127)\end{array}$ \\
\hline 1995-99 & $\begin{array}{c}-41.17^{* * *} \\
(3.883)\end{array}$ & $\begin{array}{c}-40.76^{* * *} \\
(3.866)\end{array}$ & $\begin{array}{c}-39.84^{* * *} \\
(3.860)\end{array}$ & $\begin{array}{c}-45.19^{* * *} \\
(3.636)\end{array}$ & $\begin{array}{c}-4.938^{*} \\
(2.327)\end{array}$ & $\begin{array}{c}-75.71^{* * *} \\
(2.536)\end{array}$ \\
\hline 2000-04 & $\begin{array}{c}-44.22^{* * *} \\
(4.225)\end{array}$ & $\begin{array}{c}-43.80^{* * *} \\
(4.210)\end{array}$ & $\begin{array}{c}-42.68^{* * *} \\
(4.208)\end{array}$ & $\begin{array}{c}-49.43^{* * *} \\
(3.940)\end{array}$ & $\begin{array}{c}-12.21^{* * * *} \\
(2.722)\end{array}$ & $\begin{array}{c}-84.47^{* * *} \\
(2.071)\end{array}$ \\
\hline $2005-08$ & $\begin{array}{c}-48.86^{* * *} \\
(4.500)\end{array}$ & $\begin{array}{c}-48.51^{* * *} \\
(4.482)\end{array}$ & $\begin{array}{c}-47.07^{* * *} \\
(4.487)\end{array}$ & $\begin{array}{c}-54.18^{* * *} \\
(4.228)\end{array}$ & $\begin{array}{c}-18.56^{* * * *} \\
(3.136)\end{array}$ & $\begin{array}{c}-92.33^{* * *} \\
(2.137)\end{array}$ \\
\hline Log of Population & $\begin{array}{c}-53.88^{* * *} \\
(4.990)\end{array}$ & $\begin{array}{c}-54.54^{* * *} \\
(4.985)\end{array}$ & $\begin{array}{c}-55.36^{* * *} \\
(4.970)\end{array}$ & $\begin{array}{c}-48.02^{* * *} \\
(4.659)\end{array}$ & $\begin{array}{c}-34.09^{* * * *} \\
(8.198)\end{array}$ & $\begin{array}{c}1.603 \\
(1.671)\end{array}$ \\
\hline Conflict _t-1 & $\begin{array}{l}-0.393 \\
(0.382)\end{array}$ & & & & & $\begin{array}{l}0.923^{*} \\
(0.419)\end{array}$ \\
\hline Conflict in Neighbourhood & $\begin{array}{l}-0.251 \\
(0.287)\end{array}$ & $\begin{array}{l}-0.229 \\
(0.287)\end{array}$ & $\begin{array}{l}-0.261 \\
(0.286)\end{array}$ & & & $\begin{array}{c}0.381 \\
(0.351)\end{array}$ \\
\hline Log of Battle Deaths _t-1 & & $\begin{array}{c}-0.502^{*} \\
(0.246)\end{array}$ & $\begin{array}{l}-0.124 \\
(0.276)\end{array}$ & & & \\
\hline Log of Battle Deaths _t-1 X Log of Population & & & $\begin{array}{c}-0.499^{* *} \\
(0.168)\end{array}$ & & & \\
\hline Fragility & & & & $\begin{array}{c}3.516 \\
(2.318)\end{array}$ & & \\
\hline Cumulative CPIA Score & & & & & $\begin{array}{c}-2.390^{*} \\
(1.081)\end{array}$ & \\
\hline Constant & $\begin{array}{c}609.6^{* * *} \\
(42.13)\end{array}$ & $\begin{array}{c}615.7^{* * *} \\
(42.11)\end{array}$ & $\begin{array}{c}622.7^{* * *} \\
(41.98)\end{array}$ & $\begin{array}{c}556.1^{* * *} \\
(39.07)\end{array}$ & $\begin{array}{c}415.4^{* * *} \\
(73.07)\end{array}$ & $\begin{array}{c}138.0^{* * *} \\
(14.62)\end{array}$ \\
\hline Observations & 1014 & 1014 & 1014 & 1051 & 646 & 1014 \\
\hline $\begin{array}{l}\text { Log likelihood } \\
\chi^{2}\end{array}$ & -4336.1 & -4334.3 & -4329.1 & -4494.2 & -2592.4 & 5283.8 \\
\hline
\end{tabular}


WDR Background Paper

October 26, 2010

\section{A.3.5 MDG 5: Maternal Mortality}

\section{Cross-sectional analyses}

Table A-23: Improvement in proportion of births attended, Cross-section analysis 1997-2004

\begin{tabular}{|c|c|c|c|c|c|}
\hline & $\begin{array}{c}(1) \\
\text { improvement }\end{array}$ & $\begin{array}{c}(2) \\
\text { improvement }\end{array}$ & $\begin{array}{c}(3) \\
\text { improvement }\end{array}$ & $\begin{array}{c}(4) \\
\text { improvement }\end{array}$ & $\begin{array}{c}(5) \\
\text { improvement }\end{array}$ \\
\hline exposure & $0.531^{* * *}$ & $0.547^{* * *}$ & $0.547^{* * *}$ & $0.609^{* * *}$ & 0.322 \\
\hline (firstnm) attended & $\begin{array}{c}-0.100^{* * *} \\
(0.0332)\end{array}$ & $\begin{array}{c}-0.105^{* * *} \\
(0.0322)\end{array}$ & $\begin{array}{c}-0.106 * * * \\
(0.0329)\end{array}$ & $\begin{array}{c}-0.126 * * * \\
(0.0328)\end{array}$ & $\begin{array}{c}-0.104 * * * \\
(0.0319)\end{array}$ \\
\hline logged total population & $\begin{array}{c}0.358 \\
(0.430)\end{array}$ & $\begin{array}{c}0.412 \\
(0.432)\end{array}$ & $\begin{array}{c}0.364 \\
(0.440)\end{array}$ & $\begin{array}{c}0.240 \\
(0.407)\end{array}$ & $\begin{array}{c}0.189 \\
(0.423)\end{array}$ \\
\hline $\begin{array}{l}\text { (sum) minor } \\
\text { (sum) war }\end{array}$ & $\begin{array}{c}0.293 \\
(0.441) \\
-0.413 \\
(0.698)\end{array}$ & & & & \\
\hline $\mathrm{bd} 1 \mathrm{k}$ & & $\begin{array}{l}-0.0340 \\
(0.0700)\end{array}$ & & & \\
\hline $\operatorname{lnbd}$ & & & $\begin{array}{c}-0.0230 \\
(0.217)\end{array}$ & & \\
\hline (sum) fsida & & & & $\begin{array}{c}-0.552^{* *} \\
(0.241)\end{array}$ & \\
\hline$($ sum $)$ cpia & & & & & $\begin{array}{c}0.0871 \\
(0.0584)\end{array}$ \\
\hline Constant & $\begin{array}{c}6.619 \\
(5.520)\end{array}$ & $\begin{array}{c}6.528 \\
(5.529)\end{array}$ & $\begin{array}{c}7.032 \\
(5.432)\end{array}$ & $\begin{array}{l}9.362^{*} \\
(5.408)\end{array}$ & $\begin{array}{c}9.160 \\
(5.552)\end{array}$ \\
\hline $\mathrm{N}$ & 147 & 147 & 147 & 147 & 147 \\
\hline Start & 1997.9 & 1997.9 & 1997.9 & 1997.9 & 1997.9 \\
\hline End & 2004.4 & 2004.4 & 2004.4 & 2004.4 & 2004.4 \\
\hline $\mathrm{r} 2$ & 0.255 & 0.253 & 0.252 & 0.280 & 0.264 \\
\hline
\end{tabular}

Standard errors in parentheses

* $p<0.10,{ }^{* *} p<0.05, * * * p<0.01$ 


\section{Fixed-effects models}

Table A-24: Fixed-Effects Analysis, Births Attended by Skilled Health Workers 1995-2005

\begin{tabular}{|c|c|c|c|c|c|c|}
\hline & Conflict & Battle Deaths & BD*Pop. & Fragility & CPIA & PCSE, $\operatorname{AR}(1)$ \\
\hline $1975-79$ & 0 & 0 & 0 & 0 & 0 & 0 \\
\hline & (0) & (0) & (0) & (0) & (0) & (0) \\
\hline $1980-84$ & 0 & 0 & 0 & 0 & 0 & 0 \\
\hline & (0) & (0) & (0) & (0) & (0) & (0) \\
\hline $1985-89$ & 0 & 0 & 0 & 0 & 0 & 0 \\
\hline & (0) & (0) & (0) & (0) & (0) & $(0)$ \\
\hline 1990-94 & 0 & 0 & 0 & 0 & 0 & 0 \\
\hline & (0) & (0) & (0) & (0) & (0) & (0) \\
\hline $1995-99$ & $-3.564^{* *}$ & $-3.698^{* *}$ & $-3.732^{* *}$ & 0 & 0 & 98.07 \\
\hline & $(1.264)$ & $(1.259)$ & $(1.252)$ & (0) & (0) & \\
\hline $2000-04$ & $-1.476^{*}$ & $-1.583^{*}$ & $-1.584^{*}$ & $1.323^{*}$ & 1.056 & 100.1 \\
\hline 2005-08 & $\begin{array}{c}(0.719) \\
0\end{array}$ & $\begin{array}{c}(0.710) \\
0\end{array}$ & $\begin{array}{c}(0.706) \\
0\end{array}$ & $\begin{array}{l}(0.644) \\
2.481^{* *}\end{array}$ & $2.873^{* *}$ & 103.3 \\
\hline & (0) & (0) & $(0)$ & $(0.809)$ & $(0.935)$ & \\
\hline Log of Population & $\begin{array}{l}13.38^{*} \\
(5.768)\end{array}$ & $\begin{array}{l}12.69^{*} \\
(5.755)\end{array}$ & $\begin{array}{l}12.88^{*} \\
(5.720)\end{array}$ & $\begin{array}{c}17.00^{* * *} \\
(4.438)\end{array}$ & $\begin{array}{c}20.43^{* * *} \\
(5.529)\end{array}$ & $\begin{array}{c}-2.481 \\
(0)\end{array}$ \\
\hline Conflict _t-1 & $\begin{array}{c}0.289 \\
(0.338)\end{array}$ & & & & & $\begin{array}{c}-2.043 \\
(0)\end{array}$ \\
\hline Conflict in Neighbourhood & $\begin{array}{l}0.0617 \\
(0.168)\end{array}$ & $\begin{array}{l}0.0606 \\
(0.169)\end{array}$ & $\begin{array}{l}0.0616 \\
(0.168)\end{array}$ & & & $\begin{array}{c}-0.389 \\
(0)\end{array}$ \\
\hline Log of Battle Deaths _t-1 & & $\begin{array}{c}-0.00541 \\
(0.178)\end{array}$ & $\begin{array}{c}0.159 \\
(0.206)\end{array}$ & & & \\
\hline Log of Battle Deaths _t-1 X Log of Population & & & $\begin{array}{l}-0.230 \\
(0.147)\end{array}$ & & & \\
\hline Fragility & & & & $\begin{array}{l}3.466^{*} \\
(1.509)\end{array}$ & & \\
\hline Cumulative CPIA Score & & & & & $\begin{array}{l}-1.589 \\
(0.804)\end{array}$ & \\
\hline Constant & $\begin{array}{l}-44.98 \\
(52.52)\end{array}$ & $\begin{array}{l}-38.30 \\
(52.37) \\
\end{array}$ & $\begin{array}{l}-39.80 \\
(52.04)\end{array}$ & $\begin{array}{r}-79.23^{*} \\
(39.89) \\
\end{array}$ & $\begin{array}{l}-111.2^{*} \\
(51.29) \\
\end{array}$ & $\begin{array}{c}0 \\
(0)\end{array}$ \\
\hline Observations & 244 & 244 & 244 & 258 & 215 & 244 \\
\hline $\begin{array}{l}\text { Log likelihood } \\
\chi^{2}\end{array}$ & -554.6 & -555.4 & -552.8 & -579.4 & -489.3 & . \\
\hline
\end{tabular}




\section{A.3.6 MDG 6: Combat HIV/AIDS}

\section{Cross-sectional analyses}

Table A-25: Improvement in HIV/AIDS prevalence, Cross-section analysis 1991-2003

\begin{tabular}{|c|c|c|c|c|c|}
\hline & $\begin{array}{c}\text { (1) } \\
\text { improvement }\end{array}$ & $\begin{array}{c}(2) \\
\text { improvement }\end{array}$ & $\begin{array}{c}(3) \\
\text { improvement }\end{array}$ & $\begin{array}{c}\text { (4) } \\
\text { improvement }\end{array}$ & $\begin{array}{c}(5) \\
\text { improvement }\end{array}$ \\
\hline exposure & $\begin{array}{c}0.146 \\
(0.104)\end{array}$ & $\begin{array}{c}0.110 \\
(0.106)\end{array}$ & $\begin{array}{c}0.160 \\
(0.106)\end{array}$ & $\begin{array}{c}0.147 \\
(0.104)\end{array}$ & $\begin{array}{c}0.0326 \\
(0.111)\end{array}$ \\
\hline (firstnm) hivprev & $\begin{array}{c}-0.345^{*} \\
(0.175)\end{array}$ & $\begin{array}{c}-0.397^{* *} \\
(0.179)\end{array}$ & $\begin{array}{c}-0.402^{* *} \\
(0.175)\end{array}$ & $\begin{array}{c}-0.422^{* *} \\
(0.174)\end{array}$ & $\begin{array}{c}-0.387^{* *} \\
(0.180)\end{array}$ \\
\hline logged total population & $\begin{array}{r}-0.0757 \\
(0.240)\end{array}$ & $\begin{array}{l}-0.169 \\
(0.244)\end{array}$ & $\begin{array}{l}-0.0881 \\
(0.240)\end{array}$ & $\begin{array}{l}-0.343 \\
(0.226)\end{array}$ & $\begin{array}{l}-0.396 \\
(0.244)\end{array}$ \\
\hline $\begin{array}{l}(\text { sum }) \text { minor } \\
(\text { sum }) \text { war }\end{array}$ & $\begin{array}{c}-0.280 * * \\
(0.118) \\
-0.181 \\
(0.214)\end{array}$ & & & & \\
\hline $\mathrm{bd} 1 \mathrm{k}$ & & $\begin{array}{c}-0.0551 * \\
(0.0326)\end{array}$ & & & \\
\hline $\operatorname{lnbd}$ & & & $\begin{array}{c}-0.287^{* * * *} \\
(0.105)\end{array}$ & & \\
\hline (sum) fsida & & & & $\begin{array}{c}-0.212^{* * *} \\
(0.0681)\end{array}$ & \\
\hline (sum) cpia & & & & & $\begin{array}{c}0.0272 \\
(0.0198)\end{array}$ \\
\hline Constant & $\begin{array}{c}0.411 \\
(2.792) \\
\end{array}$ & $\begin{array}{c}0.548 \\
(2.876) \\
\end{array}$ & $\begin{array}{c}0.406 \\
(2.765) \\
\end{array}$ & $\begin{array}{c}1.852 \\
(2.688)\end{array}$ & $\begin{array}{c}2.594 \\
(2.828) \\
\end{array}$ \\
\hline $\mathrm{N}$ & 123 & 123 & 123 & 123 & 123 \\
\hline Start & 1993.1 & 1993.1 & 1993.1 & 1993.1 & 1993.1 \\
\hline End & 2007.0 & 2007.0 & 2007.0 & 2007.0 & 2007.0 \\
\hline $\mathrm{r} 2$ & 0.254 & 0.211 & 0.242 & 0.256 & 0.205 \\
\hline
\end{tabular}




\section{Fixed-effects models}

Table A-26: Fixed-Effects Analysis, HIV/AIDS Sero-Prevalence 1990-2005

\begin{tabular}{|c|c|c|c|c|c|c|}
\hline & Conflict & Battle Deaths & BD*Pop. & Fragility & CPIA & PCSE, $\operatorname{AR}(1)$ \\
\hline \multirow[t]{2}{*}{ 1975-79 } & 0 & 0 & 0 & 0 & 0 & 0 \\
\hline & (0) & (0) & (0) & (0) & (0) & (0) \\
\hline \multirow[t]{2}{*}{$1980-84$} & 0 & 0 & 0 & 0 & 0 & 0 \\
\hline & (0) & (0) & (0) & (0) & (0) & (0) \\
\hline \multirow[t]{2}{*}{$1985-89$} & 0 & 0 & 0 & 0 & 0 & 0 \\
\hline & $(0)$ & (0) & (0) & $(0)$ & $(0)$ & (0) \\
\hline \multirow[t]{2}{*}{ 1990-94 } & 0 & 0 & 0 & $-1.533^{* * *}$ & 0 & 2.223 \\
\hline & (0) & (0) & (0) & $(0.428)$ & (0) & (1.329) \\
\hline \multirow[t]{2}{*}{ 1995-99 } & $1.441^{* * *}$ & $1.440^{* * *}$ & $1.427^{* * *}$ & 0 & $2.008^{* * *}$ & $3.709^{* *}$ \\
\hline & $(0.409)$ & $(0.411)$ & $(0.404)$ & (0) & $(0.543)$ & (1.308) \\
\hline \multirow[t]{2}{*}{ 2000-04 } & $1.721^{* *}$ & $1.720^{* *}$ & $1.690^{* *}$ & 0.557 & $2.790^{* * *}$ & $4.285^{* * *}$ \\
\hline & $\begin{array}{c}(0.519) \\
1.199\end{array}$ & $\begin{array}{c}(0.522) \\
1.183\end{array}$ & $(0.513)$ & $(0.407)$ & $(0.792)$ & $\begin{array}{l}(1.297) \\
4.117^{* *}\end{array}$ \\
\hline 2005-08 & $(0.641)$ & $(0.642)$ & $(0.631)$ & $(0.491)$ & $(0.996)$ & $(1.263)$ \\
\hline \multirow[t]{2}{*}{ Log of Population } & 1.970 & 2.090 & 2.446 & 1.742 & -1.083 & -0.129 \\
\hline & $(1.832)$ & $(1.828)$ & (1.801) & $(1.860)$ & $(2.939)$ & $(0.149)$ \\
\hline \multirow[t]{2}{*}{ Conflict _t-1 } & -0.0586 & & & & & -0.0370 \\
\hline & $(0.0900)$ & $0277_{* * *}$ & $0284 * * *$ & & & $(0.0609)$ \\
\hline Conflict in Neighbourhood & $\begin{aligned}-0.274 \\
(0.0642)\end{aligned}$ & $(0.0643)$ & $\begin{aligned}-0.284 \\
(0.0633)\end{aligned}$ & & & $\begin{array}{l}-0.0849 \\
(0.0776)\end{array}$ \\
\hline Log of Battle Deaths _t- 1 & & $\begin{array}{l}-0.0164 \\
(0.0615)\end{array}$ & $\begin{array}{c}0.0188 \\
(0.0615)\end{array}$ & & & \\
\hline \multicolumn{2}{|l|}{ Log of Battle Deaths _t-1 X Log of Population } & & $\begin{array}{c}-0.172^{* *} \\
(0.0544)\end{array}$ & & & \\
\hline Fragility & & & & $\begin{array}{c}-0.867 \\
(0.609)\end{array}$ & & \\
\hline Cumulative CPIA Score & & & & & $\begin{array}{c}-0.234 \\
(0.327)\end{array}$ & \\
\hline Constant & $\begin{array}{l}-14.73 \\
(15.95)\end{array}$ & $\begin{array}{l}-15.82 \\
(15.91)\end{array}$ & $\begin{array}{c}-18.71 \\
(15.68)\end{array}$ & $\begin{array}{l}-12.82 \\
(16.37)\end{array}$ & $\begin{array}{c}11.11 \\
(25.97)\end{array}$ & $\begin{array}{c}0 \\
(0)\end{array}$ \\
\hline Observations & 386 & 386 & 386 & 389 & 334 & 386 \\
\hline Log likelihood & -803.0 & -803.3 & -796.1 & -827.0 & -712.7 & \\
\hline$\chi^{2}$ & & & & & & 179.8 \\
\hline
\end{tabular}

Standard errors in parentheses

${ }^{*} p<0.05,{ }^{* *} p<0.01,{ }^{* * *} p<0.001$ 
WDR Background Paper

October 26, 2010

\section{A.3.7 MDG 7: Environmental Sustainability}

\section{Cross-sectional analyses}

Table A-27: Improvement in percentage with access to safe water, Cross-section analysis 1991-2003

\begin{tabular}{|c|c|c|c|c|c|}
\hline & $\begin{array}{c}(1) \\
\text { improvement }\end{array}$ & $\begin{array}{c}(2) \\
\text { improvement }\end{array}$ & $\begin{array}{c}(3) \\
\text { improvement }\end{array}$ & $\begin{array}{c}(4) \\
\text { improvement }\end{array}$ & $\begin{array}{c}(5) \\
\text { improvement }\end{array}$ \\
\hline exposure & $\begin{array}{c}0.430^{* *} \\
(0.194)\end{array}$ & $\begin{array}{c}0.441^{* *} \\
(0.192)\end{array}$ & $\begin{array}{c}0.431^{* *} \\
(0.192)\end{array}$ & $\begin{array}{c}0.434^{* *} \\
(0.187)\end{array}$ & $\begin{array}{c}0.221 \\
(0.216)\end{array}$ \\
\hline (firstnm) water & $\begin{array}{c}-0.299 * * * \\
(0.0392)\end{array}$ & $\begin{array}{c}-0.302 * * * \\
(0.0386)\end{array}$ & $\begin{array}{c}-0.312^{* * * *} \\
(0.0394)\end{array}$ & $\begin{array}{c}-0.339 * * * \\
(0.0396)\end{array}$ & $\begin{array}{c}-0.301 * * * \\
(0.0391)\end{array}$ \\
\hline logged total population & $\begin{array}{c}0.889 * * \\
(0.432)\end{array}$ & $\begin{array}{l}1.026^{* *} \\
(0.417)\end{array}$ & $\begin{array}{l}1.037^{* *} \\
(0.425)\end{array}$ & $\begin{array}{c}0.551 \\
(0.395)\end{array}$ & $\begin{array}{c}0.535 \\
(0.418)\end{array}$ \\
\hline $\begin{array}{l}\text { (sum) minor } \\
\text { (sum) war }\end{array}$ & $\begin{array}{c}0.125 \\
(0.208) \\
-0.618^{* *} \\
(0.298)\end{array}$ & & & & \\
\hline $\mathrm{bd} 1 \mathrm{k}$ & & $\begin{array}{c}-0.0830^{* *} \\
(0.0322)\end{array}$ & & & \\
\hline $\operatorname{lnbd}$ & & & $\begin{array}{c}-0.398^{* *} \\
(0.176)\end{array}$ & & \\
\hline (sum) fsida & & & & $\begin{array}{c}-0.459 * * * \\
(0.127)\end{array}$ & \\
\hline (sum) cpia & & & & & $\begin{array}{l}0.0633^{*} \\
(0.0333)\end{array}$ \\
\hline Constant & $\begin{array}{c}13.96^{* *} \\
(6.216)\end{array}$ & $\begin{array}{l}13.61 * * \\
(6.125)\end{array}$ & $\begin{array}{c}14.92 * * \\
(6.129)\end{array}$ & $\begin{array}{c}20.62^{* * *} * \\
(6.153)\end{array}$ & $\begin{array}{c}18.71^{* * *} * \\
(6.440)\end{array}$ \\
\hline $\mathrm{N}$ & 147 & 147 & 147 & 147 & 147 \\
\hline Start & 1991.7 & 1991.7 & 1991.7 & 1991.7 & 1991.7 \\
\hline End & 2005.5 & 2005.5 & 2005.5 & 2005.5 & 2005.5 \\
\hline $\mathrm{r} 2$ & 0.468 & 0.477 & 0.471 & 0.499 & 0.466 \\
\hline
\end{tabular}

Standard errors in parentheses

* $p<0.10,{ }^{* *} p<0.05, * * * \quad p<0.01$

Table A-28: Improvement in percentage with access to sanitation, Cross-section analysis 1991-2003

\begin{tabular}{|c|c|c|c|c|c|}
\hline & $\begin{array}{c}\text { (1) } \\
\text { improvement }\end{array}$ & $\begin{array}{c}(2) \\
\text { improvement }\end{array}$ & $\begin{array}{c}(3) \\
\text { improvement }\end{array}$ & $\begin{array}{c}(4) \\
\text { improvement }\end{array}$ & $\begin{array}{c}(5) \\
\text { improvement }\end{array}$ \\
\hline exposure & $\begin{array}{c}0.495^{* *} \\
(0.195)\end{array}$ & $\begin{array}{l}0.485^{* *} \\
(0.193)\end{array}$ & $\begin{array}{l}0.498^{* *} \\
(0.193)\end{array}$ & $\begin{array}{c}0.500^{* *} \\
(0.193)\end{array}$ & $\begin{array}{l}0.435^{* *} \\
(0.205)\end{array}$ \\
\hline (firstnm) sanitation & $\begin{array}{c}-0.178^{* * *} * \\
(0.0357)\end{array}$ & $\begin{array}{c}-0.177 * * * \\
(0.0347)\end{array}$ & $\begin{array}{c}-0.180 * * * \\
(0.0356)\end{array}$ & $\begin{array}{c}-0.187 * * * \\
(0.0370)\end{array}$ & $\begin{array}{c}-0.175 * * * \\
(0.0347)\end{array}$ \\
\hline logged total population & $\begin{array}{l}0.866^{*} \\
(0.445)\end{array}$ & $\begin{array}{l}0.770^{*} \\
(0.433)\end{array}$ & $\begin{array}{c}0.912^{* *} \\
(0.439)\end{array}$ & $\begin{array}{l}0.805^{*} \\
(0.418)\end{array}$ & $\begin{array}{l}0.763^{*} \\
(0.427)\end{array}$ \\
\hline $\begin{array}{l}(\text { sum }) \text { minor } \\
(\text { sum }) \text { war }\end{array}$ & $\begin{array}{c}-0.0226 \\
(0.227) \\
-0.00160 \\
(0.300)\end{array}$ & & & & \\
\hline $\mathrm{bd} 1 \mathrm{k}$ & & $\begin{array}{c}0.0210 \\
(0.0335)\end{array}$ & & & \\
\hline $\operatorname{lnbd}$ & & & $\begin{array}{c}-0.0733 \\
(0.179)\end{array}$ & & \\
\hline (sum) fsida & & & & $\begin{array}{l}-0.101 \\
(0.135)\end{array}$ & \\
\hline (sum) cpia & & & & & $\begin{array}{c}0.0269 \\
(0.0329)\end{array}$ \\
\hline Constant & $\begin{array}{c}4.810 \\
(5.774)\end{array}$ & $\begin{array}{c}5.472 \\
(5.675)\end{array}$ & $\begin{array}{c}4.738 \\
(5.615)\end{array}$ & $\begin{array}{c}6.016 \\
(5.793)\end{array}$ & $\begin{array}{c}5.645 \\
(5.668) \\
\end{array}$ \\
\hline $\mathrm{N}$ & 143 & 143 & 143 & 143 & 143 \\
\hline Start & 1991.8 & 1991.8 & 1991.8 & 1991.8 & 1991.8 \\
\hline End & 2005.6 & 2005.6 & 2005.6 & 2005.6 & 2005.6 \\
\hline $\mathrm{r} 2$ & 0.394 & 0.396 & 0.395 & 0.397 & 0.397 \\
\hline
\end{tabular}

Standard errors in parentheses

${ }^{*} p<0.10,{ }^{* *} p<0.05,{ }^{* * *} p<0.01$ 


\section{Fixed-effects models}

Table A-29: Fixed-Effects Analysis, Access to Water 1990-2005

\begin{tabular}{|c|c|c|c|c|c|c|}
\hline & Conflict & Battle Deaths & BD*Pop. & Fragility & CPIA & PCSE, $\operatorname{AR}(1)$ \\
\hline $1975-79$ & $\begin{array}{c}0 \\
(0)\end{array}$ & $\begin{array}{c}0 \\
(0)\end{array}$ & $\begin{array}{c}0 \\
(0)\end{array}$ & $\begin{array}{c}0 \\
(0)\end{array}$ & $\begin{array}{c}0 \\
(0)\end{array}$ & $\begin{array}{c}0 \\
(0)\end{array}$ \\
\hline $1980-84$ & 0 & 0 & 0 & 0 & 0 & 0 \\
\hline & (0) & (0) & (0) & (0) & (0) & (0) \\
\hline $1985-89$ & 0 & 0 & 0 & 0 & 0 & 0 \\
\hline & (0) & (0) & (0) & (0) & (0) & (0) \\
\hline 1990-94 & $\begin{array}{c}0 \\
(0)\end{array}$ & $\begin{array}{c}0 \\
(0)\end{array}$ & $\begin{array}{c}0 \\
(0)\end{array}$ & $\begin{array}{c}0 \\
(0)\end{array}$ & $\begin{array}{c}0 \\
(0)\end{array}$ & $\begin{array}{l}-7.097 \\
(0)\end{array}$ \\
\hline 1995-99 & $\begin{array}{c}2.051^{* *} \\
(0.637)\end{array}$ & $\begin{array}{c}2.008^{* *} \\
(0.638)\end{array}$ & $\begin{array}{c}2.009 * * \\
(0.638)\end{array}$ & $\begin{array}{c}2.085^{* *} \\
(0.643)\end{array}$ & $\begin{array}{l}1.658^{*} \\
(0.800)\end{array}$ & $\begin{array}{c}-4.580 \\
(0)\end{array}$ \\
\hline $2000-04$ & $\begin{array}{c}4.150^{* * *} \\
(0.817)\end{array}$ & $\begin{array}{c}4.054^{* * * *} \\
(0.817)\end{array}$ & $\begin{array}{c}4.073^{* * *} \\
(0.818)\end{array}$ & $\begin{array}{c}3.894^{* * *} \\
(0.787)\end{array}$ & $\begin{array}{l}3.384^{* *} \\
(1.047)\end{array}$ & $\begin{array}{c}-2.005 \\
(0)\end{array}$ \\
\hline $2005-08$ & $\begin{array}{c}6.424^{* * *} \\
(1.023)\end{array}$ & $\begin{array}{c}6.229^{* * *} \\
(1.021)\end{array}$ & $\begin{array}{c}6.283^{* * *} \\
(1.023)\end{array}$ & $\begin{array}{c}5.826^{* * *} \\
(0.955)\end{array}$ & $\begin{array}{c}5.409^{* * *} \\
(1.277)\end{array}$ & $\begin{array}{l}0 \\
(0)\end{array}$ \\
\hline Log of Population & $\begin{array}{c}4.503 \\
(2.980)\end{array}$ & $\begin{array}{c}5.263 \\
(2.955)\end{array}$ & $\begin{array}{c}5.245 \\
(2.956)\end{array}$ & $\begin{array}{c}7.485^{* *} \\
(2.784)\end{array}$ & $\begin{array}{l}11.82^{* *} \\
(3.828)\end{array}$ & $\begin{array}{c}-1.026 \\
(0)\end{array}$ \\
\hline Conflict_t-1 & $\begin{array}{c}-0.398^{* *} \\
(0.139)\end{array}$ & & & & & $\begin{array}{c}-0.733 \\
(0)\end{array}$ \\
\hline Conflict in Neighbourhood & $\begin{array}{l}0.0978 \\
(0.101)\end{array}$ & $\begin{array}{l}0.0927 \\
(0.101)\end{array}$ & $\begin{array}{l}0.0873 \\
(0.101)\end{array}$ & & & $\begin{array}{l}-0.147 \\
(0)\end{array}$ \\
\hline Log of Battle Deaths _t-1 & & $\begin{array}{l}-0.233^{*} \\
(0.0941)\end{array}$ & $\begin{array}{l}-0.185 \\
(0.110)\end{array}$ & & & \\
\hline Log of Battle Deaths _t-1 X Log of Population & & & $\begin{array}{l}-0.0557 \\
(0.0661)\end{array}$ & & & \\
\hline Fragility & & & & $\begin{array}{c}1.881 \\
(1.100)\end{array}$ & & \\
\hline Cumulative CPIA Score & & & & & $\begin{array}{l}-0.287 \\
(0.502)\end{array}$ & \\
\hline Constant & $\begin{array}{c}33.47 \\
(26.38) \\
\end{array}$ & $\begin{array}{c}26.72 \\
(26.14) \\
\end{array}$ & $\begin{array}{c}26.92 \\
(26.15)\end{array}$ & $\begin{array}{c}6.768 \\
(24.62) \\
\end{array}$ & $\begin{array}{l}-34.86 \\
(34.41) \\
\end{array}$ & 92.02 \\
\hline Observations & 500 & 500 & 500 & 518 & 420 & 500 \\
\hline $\begin{array}{l}\text { Log likelihood } \\
\chi^{2}\end{array}$ & -1329.6 & -1331.1 & -1330.6 & -1391.4 & -1121.8 & . \\
\hline
\end{tabular}

Table A-30: Fixed-Effects Analysis, Access to Sanitation Facilities 1990-2005

\begin{tabular}{|c|c|c|c|c|c|c|}
\hline & Conflict & Battle Deaths & BD*Pop. & Fragility & CPIA & PCSE, $\operatorname{AR}(1)$ \\
\hline $1975-79$ & $\begin{array}{c}0 \\
(0)\end{array}$ & $\begin{array}{c}0 \\
(0)\end{array}$ & $\begin{array}{c}0 \\
(0)\end{array}$ & $\begin{array}{c}0 \\
(0)\end{array}$ & $\begin{array}{c}0 \\
(0)\end{array}$ & $\begin{array}{c}0 \\
(0)\end{array}$ \\
\hline $1980-84$ & $\begin{array}{c}0 \\
(0)\end{array}$ & $\begin{array}{c}0 \\
(0)\end{array}$ & $\begin{array}{c}0 \\
(0)\end{array}$ & $\begin{array}{c}0 \\
(0)\end{array}$ & $\begin{array}{c}0 \\
(0)\end{array}$ & $\begin{array}{c}0 \\
(0)\end{array}$ \\
\hline $1985-89$ & $\begin{array}{c}0 \\
(0)\end{array}$ & $\begin{array}{c}0 \\
(0)\end{array}$ & $\begin{array}{l}0 \\
(0)\end{array}$ & $\begin{array}{c}0 \\
(0)\end{array}$ & $\begin{array}{c}0 \\
(0)\end{array}$ & $\begin{array}{l}0 \\
(0)\end{array}$ \\
\hline $1990-94$ & $\begin{array}{c}0 \\
(0)\end{array}$ & $\begin{array}{c}0 \\
(0)\end{array}$ & $\begin{array}{c}0 \\
(0)\end{array}$ & $\begin{array}{c}0 \\
(0)\end{array}$ & $\begin{array}{c}0 \\
(0)\end{array}$ & $\begin{array}{c}75.92^{* * *} \\
(11.41)\end{array}$ \\
\hline 1995-99 & $\begin{array}{c}2.286^{* * *} \\
(0.616)\end{array}$ & $\begin{array}{c}2.217^{* * *} \\
(0.619)\end{array}$ & $\begin{array}{c}2.215^{* * *} \\
(0.619)\end{array}$ & $\begin{array}{c}2.260^{* * * *} \\
(0.605)\end{array}$ & $\begin{array}{c}2.390^{* * *} \\
(0.671)\end{array}$ & $\begin{array}{c}78.48^{* * * *} \\
(11.54)\end{array}$ \\
\hline $2000-04$ & $\begin{array}{c}4.493^{* * *} \\
(0.787)\end{array}$ & $\begin{array}{c}4.381^{* * *} \\
(0.789)\end{array}$ & $\begin{array}{c}4.376^{* * *} \\
(0.790)\end{array}$ & $\begin{array}{l}3.967^{* * *} \\
(0.738)\end{array}$ & $\begin{array}{c}4.124^{* * *} \\
(0.881)\end{array}$ & $\begin{array}{c}81.10^{* * *} \\
(11.43)\end{array}$ \\
\hline 2005-08 & $\begin{array}{c}6.341^{* * *} \\
(0.986)\end{array}$ & $\begin{array}{c}6.173^{* * * *} \\
(0.986)\end{array}$ & $\begin{array}{c}6.155^{* * *} \\
(0.989)\end{array}$ & $\begin{array}{c}5.706^{* * * *} \\
(0.895)\end{array}$ & $\begin{array}{c}5.914^{* * *} \\
(1.075)\end{array}$ & $\begin{array}{c}82.86^{* * * *} \\
(11.27)\end{array}$ \\
\hline Log of Population & $\begin{array}{l}2.106 \\
(2.861)\end{array}$ & $\begin{array}{c}2.888 \\
(2.843)\end{array}$ & $\begin{array}{c}2.893 \\
(2.847)\end{array}$ & $\begin{array}{l}4.777 \\
(2.610)\end{array}$ & $\begin{array}{l}6.261 \\
(3.245)\end{array}$ & $\begin{array}{l}-1.951 \\
(1.153)\end{array}$ \\
\hline Conflict _t-1 & $\begin{array}{c}-0.267^{*} \\
(0.133)\end{array}$ & & & & & $\begin{array}{c}-0.503^{* *} \\
(0.174)\end{array}$ \\
\hline Conflict in Neighbourhood & $\begin{array}{l}-0.0625 \\
(0.0987)\end{array}$ & $\begin{array}{l}-0.0664 \\
(0.0991)\end{array}$ & $\begin{array}{l}-0.0640 \\
(0.0995)\end{array}$ & & & $\begin{array}{l}-0.183 \\
(0.172)\end{array}$ \\
\hline Log of Battle Deaths _t-1 & & $\begin{array}{l}-0.0815 \\
(0.0916)\end{array}$ & $\begin{array}{l}-0.102 \\
(0.111)\end{array}$ & & & \\
\hline Log of Battle Deaths _t-1 X Log of Population & & & $\begin{array}{c}0.0213 \\
(0.0666)\end{array}$ & & & \\
\hline Fragility & & & & $\begin{array}{c}0.679 \\
(1.017)\end{array}$ & & \\
\hline Cumulative CPIA Score & & & & & $\begin{array}{l}0.0118 \\
(0.423)\end{array}$ & \\
\hline Constant & $\begin{array}{c}37.58 \\
(25.41)\end{array}$ & $\begin{array}{c}30.44 \\
(25.24)\end{array}$ & $\begin{array}{c}30.38 \\
(25.27)\end{array}$ & $\begin{array}{c}13.77 \\
(23.17)\end{array}$ & $\begin{array}{l}-5.769 \\
(29.23)\end{array}$ & $\begin{array}{c}0 \\
(0) \\
\end{array}$ \\
\hline Observations & 485 & 485 & 485 & 502 & 412 & 485 \\
\hline $\begin{array}{l}\text { Log likelihood } \\
\chi^{2}\end{array}$ & -1267.3 & -1269.6 & -1269.6 & -1310.1 & -1022.7 & 1396.4 \\
\hline
\end{tabular}


WDR Background Paper

October 26, 2010

Regression results underlying Figure 5 
Table A-31: Effect of Conflict on Annual Growth in GDP per Capita (PPP, logged),

\begin{tabular}{|c|c|}
\hline & $\begin{array}{c}(1) \\
\text { Growth }\end{array}$ \\
\hline $\operatorname{lgdpcp}$ & $\begin{array}{r}-0.00267^{*} \\
(0.00109)\end{array}$ \\
\hline conflict & $\begin{array}{r}-0.0192^{* * *} \\
(0.00270)\end{array}$ \\
\hline conflict_1 & $\begin{array}{l}-0.00685^{*} \\
(0.00321)\end{array}$ \\
\hline conflict_2 & $\begin{array}{c}0.00502 \\
(0.00325)\end{array}$ \\
\hline conflict_3 & $\begin{array}{c}0.00191 \\
(0.00329)\end{array}$ \\
\hline conflict_4 & $\begin{array}{l}0.00691^{*} \\
(0.00325)\end{array}$ \\
\hline conflict_5 & $\begin{array}{r}0.00902^{* * *} \\
(0.00273)\end{array}$ \\
\hline $\operatorname{td} 75$ & $\begin{array}{r}-0.0113^{* * *} \\
(0.00325)\end{array}$ \\
\hline $\operatorname{td} 80$ & $\begin{array}{r}-0.0316^{* * *} \\
(0.00321)\end{array}$ \\
\hline $\operatorname{td} 85$ & $\begin{array}{r}-0.0227^{* * *} \\
(0.00323)\end{array}$ \\
\hline $\operatorname{td} 90$ & $\begin{array}{r}-0.0304^{* * *} \\
(0.00326)\end{array}$ \\
\hline $\operatorname{td} 95$ & $\begin{array}{r}-0.0148^{* * *} \\
(0.00329)\end{array}$ \\
\hline $\operatorname{td} 00$ & $\begin{array}{r}-0.0187^{* * *} \\
(0.00334)\end{array}$ \\
\hline $\operatorname{td} 05$ & $\begin{array}{l}-0.00586 \\
(0.00356)\end{array}$ \\
\hline regionb $==\mathrm{ECA}$ & $\begin{array}{c}0.0139 \\
(0.00969)\end{array}$ \\
\hline regionb $==\mathrm{LAC}$ & $\begin{array}{r}-0.0197^{* * *} \\
(0.00344)\end{array}$ \\
\hline region $b==\mathrm{MNA}$ & $\begin{array}{r}-0.0164^{* * *} \\
(0.00382)\end{array}$ \\
\hline region $b==\mathrm{OECD}$ & $\begin{array}{r}-0.0155^{* * *} \\
(0.00413)\end{array}$ \\
\hline regionb $==\mathrm{SAR}$ & $\begin{array}{l}-0.00861 \\
(0.00487)\end{array}$ \\
\hline region $b==\mathrm{SSA}$ & $\begin{array}{r}-0.0229^{* * *} \\
(0.00363)\end{array}$ \\
\hline ethfra & $\begin{array}{c}-0.0161^{* * *} \\
(0.00367)\end{array}$ \\
\hline $\begin{array}{l}\text { fraction of pop with attained secondary education } \\
\qquad 84\end{array}$ & $\begin{array}{l}0.0215^{* * *} \\
(0.00571)\end{array}$ \\
\hline $\operatorname{lnpop}$ & $\begin{array}{c}0.00138^{*} \\
(0.000575)\end{array}$ \\
\hline Constant & $\begin{array}{c}0.0542^{* * *} \\
(0.0103)\end{array}$ \\
\hline
\end{tabular}

